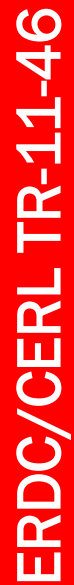

\section{The Use of Natural Pozzolan in Concrete as an Additive or Substitute for Cement}

Ghassan K. Al-Chaar, Mouin Alkadi, David A. Yaksic,

December 2011 and Lisa A. Kallemeyn

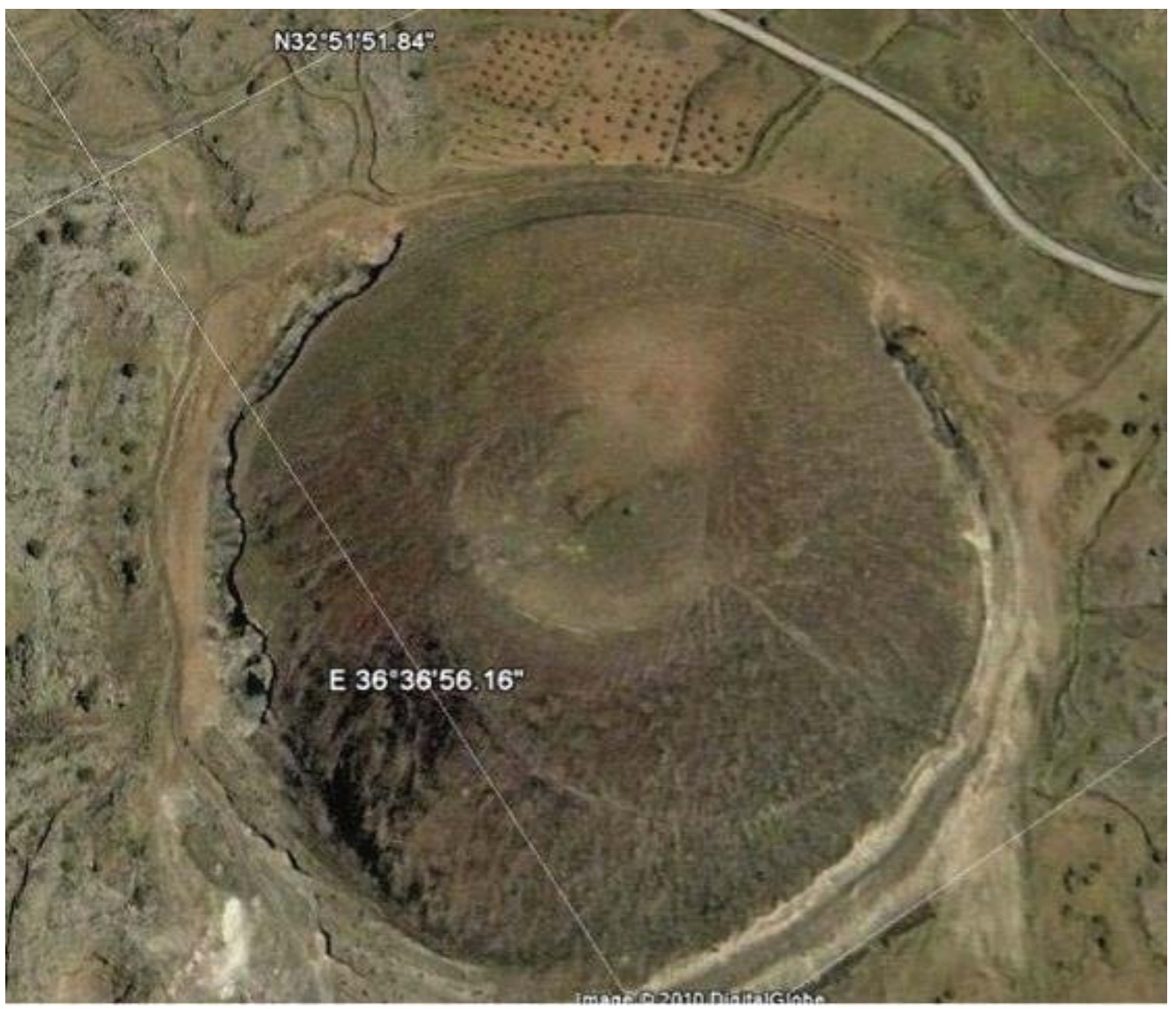





\title{
The Use of Natural Pozzolan in Concrete as an Additive or Substitute for Cement
}

\author{
Ghassan K. Al-Chaar, David A. Yaksic, and Lisa A. Kallemeyn \\ Construction Engineering Research Laboratory \\ U.S. Army Engineer Research and Development Center \\ 2902 Newmark Drive \\ Champaign, IL 61822 \\ Mouin Alkadi \\ Arabian Building Support and Rehabilitation (ABSAR) Co., Ltd. \\ P. O. Box 56955 \\ Riyadh 11564 \\ Saudi Arabia
}

Final report

Approved for public release; distribution is unlimited.

$\begin{aligned} \text { Prepared for } & \text { U.S. Army Corps of Engineers } \\ & \text { Washington, DC 20314-1000 } \\ \text { Under } & \text { The ERDC Long-Term Training Program }\end{aligned}$ 


\begin{abstract}
Chemical, physical, and mechanical tests were conducted to assess the feasibility of using naturally occurring pozzolan as a cement mortar additive. One test series assessed the feasibility of substituting pozzolan for a portion of cement in concrete mortar mixtures. The chemical composition of five natural pozzolans was determined. Compressive testing was conducted on specimens with varying amounts and types of pozzolan. One pozzolan was found suitable for cement replacement in Type M mortars, and one was suitable for cement replacement in Type $\mathrm{N}$ mortars at a different proportion. The results indicate that, within certain mixture percentage limits, partial replacement of cement with pozzolan does not compromise mortar compressive strength.
\end{abstract}

\begin{abstract}
A second test series evaluated four mixes prepared using three types of natural pozzolan as well as Class F fly ash. The effectiveness of each cement replacement material in controlling alkali-silica reactions was studied. Correlations were made between the mechanical properties of the proposed mixes and a Portland cement control mix. The results were also compared with industry standards for mortars made with fly ash and silica fume. Results indicate that one type of pozzolan may be used as a substitute for fly ash, but not for silica fume.
\end{abstract}

DISCLAIMER: The contents of this report are not to be used for advertising, publication, or promotional purposes. Citation of trade names does not constitute an official endorsement or approval of the use of such commercial products. All product names and trademarks cited are the property of their respective owners. The findings of this report are not to be construed as an official Department of the Army position unless so designated by other authorized documents. 


\section{Table of Contents}

List of Figures and Tables............................................................................................................................

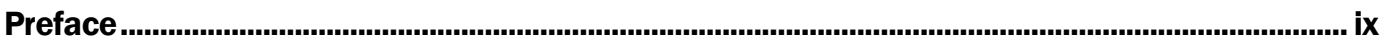

Unit Conversion Factors ...............................................................................................................................

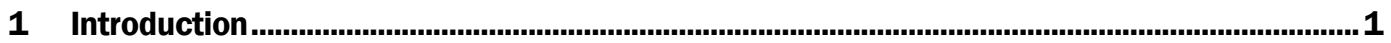

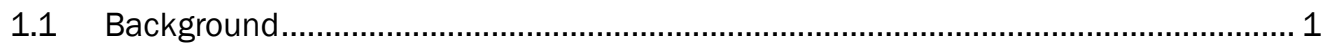

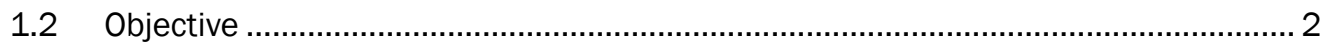

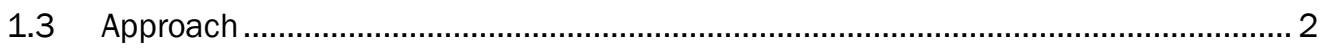

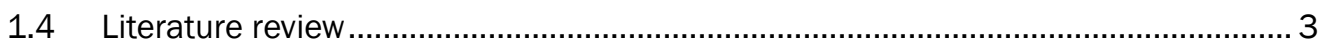

2 Scanning Electron Microscopy Tests of Pozzolan Composition ............................................... 5

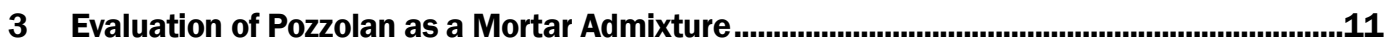

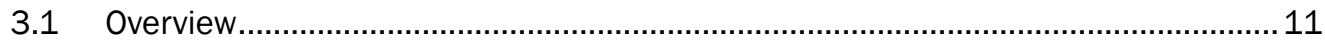

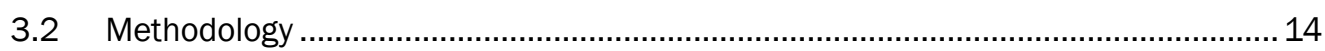

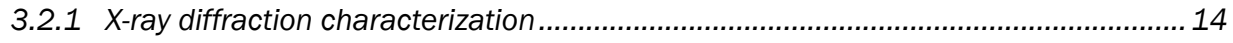

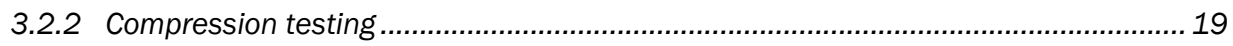

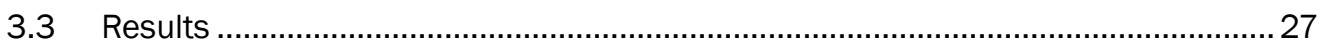

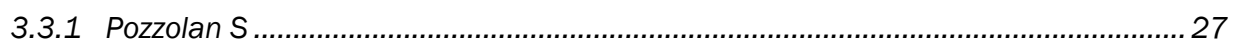

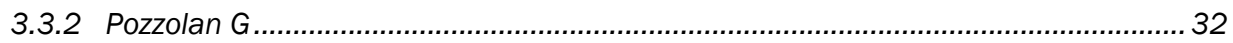

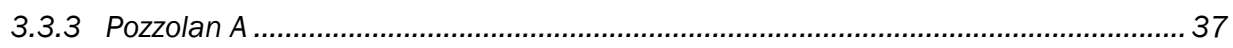

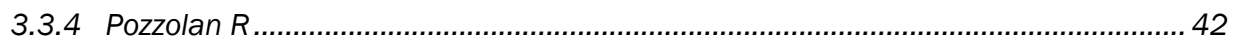

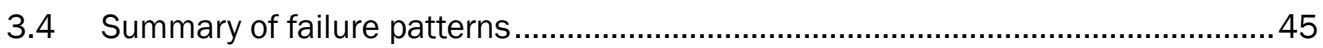

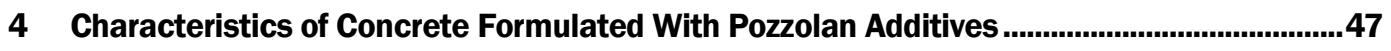

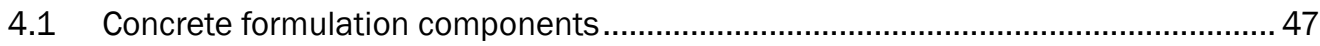

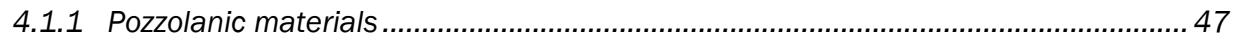

4.1.2 Portland cement............................................................................................... 48

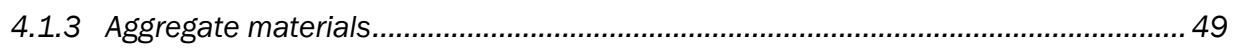

4.2 Compressive strength testing ..................................................................... 53

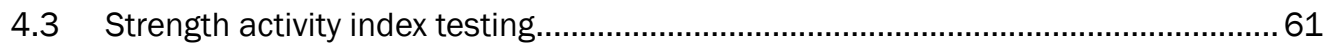

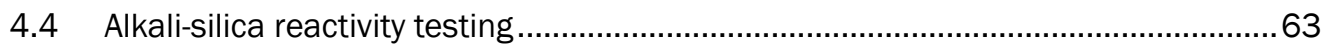

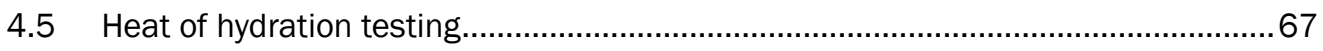

4.6 Effect of pozzolan and water-to-cement ratio on slump.........................................68

4.7 Effect of pozzolan and water-to-cement ratio on strength ..................................... 71

5 Comparison of Pozzolan with ASTM Specifications for Fly Ash and Silica Fume .................80

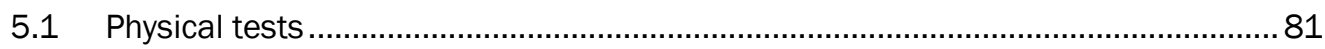

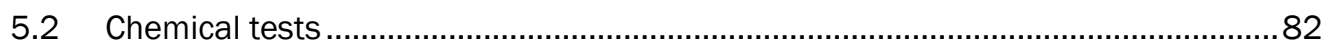

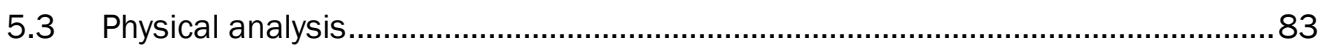

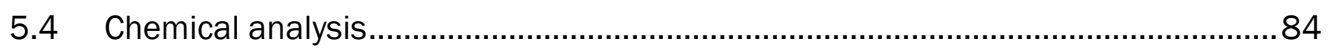




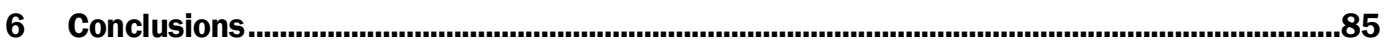

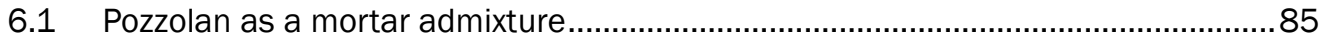

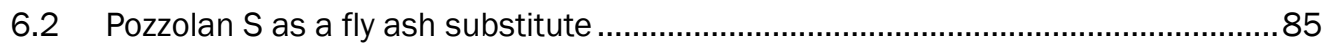

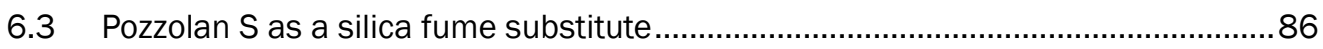

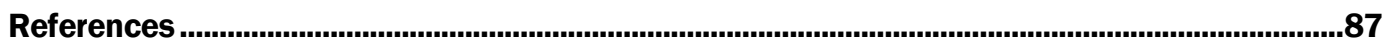

Report Documentation Page 


\section{List of Figures and Tables}

\section{Figures}

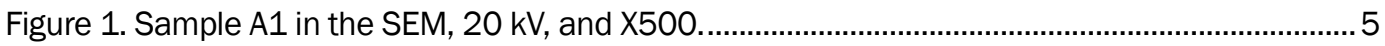

Figure 2. Sample A1 in the SEM, $20 \mathrm{kV}$, and X2,000 ..................................................................... 5

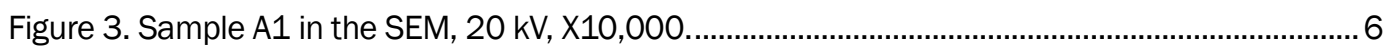

Figure 4. Sample B1 in SEM, 20 kV, X100 .................................................................................. 6

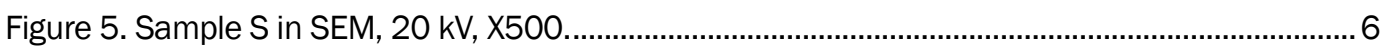

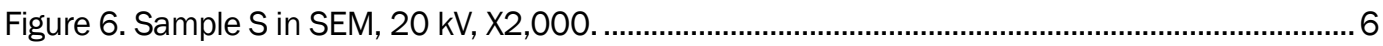

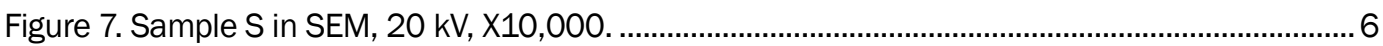

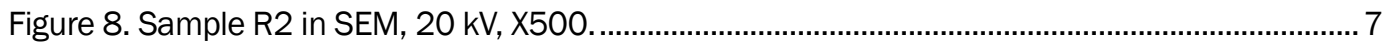

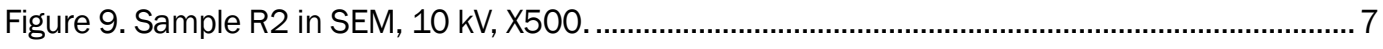

Figure 10. Sample R2 in SEM, 20 kV, X2,000............................................................................ 7

Figure 11. Sample R2 in SEM, 10 kV, X2,000

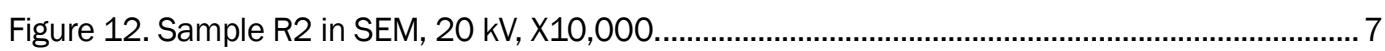

Figure 13. Sample R2 in SEM, 10kV, X10,000.........................................................................

Figure 14. Plot of SEM/EDS results for sample A1 ................................................................. 8

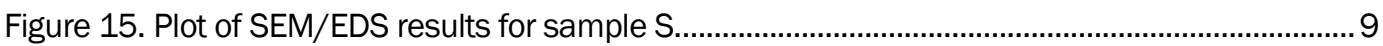

Figure 16. Plot of SEM/EDS results for sample R2 …….......................................................10

Figure 17. Satellite image of Shehan pozzolan with global positioning coordinates. .........................12

Figure 18. Satellite image of Grara pozzolan with global positioning coordinates. …….....................12

Figure 19. Satellite image of Ardh pozzolan with global positioning coordinates. .............................13

Figure 20. Satellite image of Rsas pozzolan with global positioning coordinates..............................13

Figure 21. Schematic of setup with relevant angles indicated..........................................................14

Figure 22. Typical stones used for mechanical crushing of pozzolan samples..................................15

Figure 23. Jar and roller apparatus used to grind pozzolan samples................................................15

Figure 24. Dish where the powder sample is loaded.....................................................................

Figure 25. Spring and locking mechanism for the dish.................................................................16

Figure 26. Assembled sample holder without sample loaded. ...........................................................16

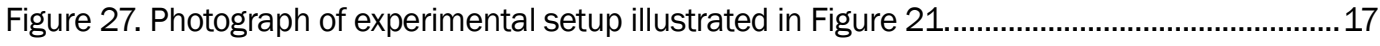

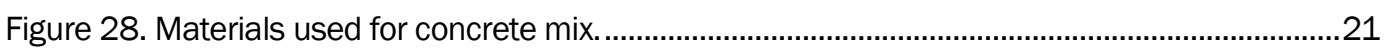

Figure 29. Measuring equipment for concrete mix. ......................................................................21

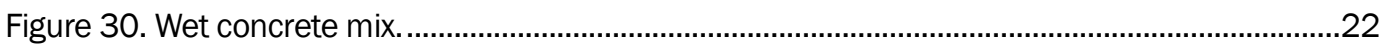

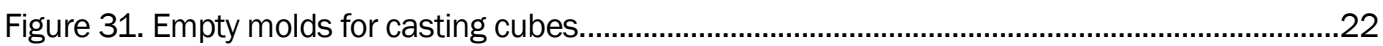

Figure 32. Concrete setting in cube molds..................................................................................2

Figure 33. Cast cubes kept moist under paper towels. ...................................................................23

Figure 34. 50 kip loading machine.........................................................................................................2 


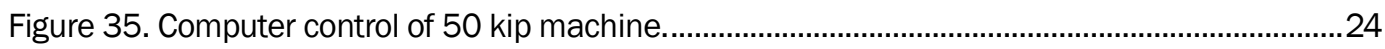

Figure 36. Cubes with faces to be compressed marked. ................................................................25

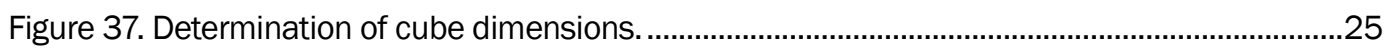

Figure 38. Extensometer attached to specimen........................................................................26

Figure 39. Specimen ready for compression test.........................................................................26

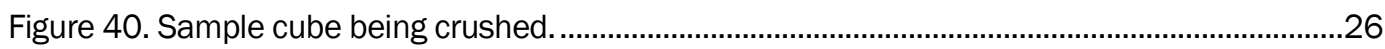

Figure 42. Jade element intensity results superimposed over XRD results for Pozzolan S...............28

Figure 43. Location of major peak intensities of the elements in Pozzolan S.................................28

Figure 44. Graphical representation of components of Pozzolan S. ...............................................29

Figure 45. Stress/strain diagram of Set 1 for Pozzolan S. ..............................................................30

Figure 46. Stress/strain diagram of Set 2 for Pozzolan S. ..............................................................31

Figure 47. Stress/strain diagram of Set 3 for Pozzolan S...............................................................31

Figure 48. Stress/strain diagram of Set 4 for Pozzolan S. ................................................................31

Figure 49. Stress/strain diagram of Set 5 for Pozzolan S. .................................................................32

Figure 50. Stress/strain diagram of Set 6 for Pozzolan S. .............................................................32

Figure 51. Jade element intensity results superimposed over XRD results for Pozzolan G...............33

Figure 52. Location of major peak intensities of the elements in Pozzolan G. ................................34

Figure 53. Graphical representation of components of Pozzolan G................................................34

Figure 54. Stress/strain diagram of Set 2 for Pozzolan G............................................................35

Figure 55. Stress/strain diagram of Set 3 for Pozzolan G.............................................................36

Figure 56. Stress/strain diagram of Set 5 for Pozzolan G...............................................................36

Figure 57. Stress/strain diagram of Set 6 for Pozzolan G. ..............................................................36

Figure 58. Jade element intensity results superimposed over XRD results for Pozzolan A...............38

Figure 59. Location of major peak intensities of the elements in Pozzolan A...................................38

Figure 60. Stress/strain diagram of Set 1 for Pozzolan A. .................................................................40

Figure 61. Stress/strain diagram of Set 2 for Pozzolan A. ...............................................................40

Figure 62. Stress/strain diagram of Set 3 for Pozzolan A. ...............................................................40

Figure 63. Stress/strain diagram of Set 4 for Pozzolan A. .............................................................. 41

Figure 64. Stress/strain diagram of Set 5 for Pozzolan A. ............................................................... 41

Figure 65. Stress/strain diagram of Set 6 for Pozzolan A .............................................................. 41

Figure 66. Jade element intensity results superimposed over XRD results for Pozzolan R2............42

Figure 67. Location of major peak intensities of the elements in Pozzolan R2 ................................42

Figure 68. Jade element intensity results superimposed over XRD results for Pozzolan R1 ...........43

Figure 69. Location of major peak intensities of the elements in Pozzolan R1 .................................44

Figure 70. Graphical representation of components of Pozzolan R1..............................................44

Figure 71. Failure pattern of all specimens. ................................................................................4

Figure 72. Sifting of $3 / 4$ inch aggregate.................................................................................. 51

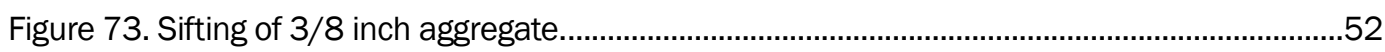

Figure 74. Sifting of fine silica sand..........................................................................................

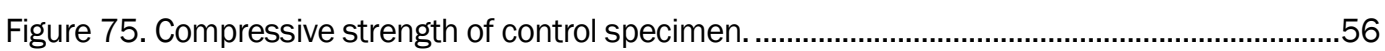


Figure 76. Compressive strength of test specimens with fly ash. ...................................................56

Figure 77. Graph of compressive strength of test specimens with Pozzolan J..................................57

Figure 78. Graph of compressive strength of specimens with Pozzolan S1 ....................................57

Figure 79. Graph of compressive strength of specimens with Pozzolan S2 ..................................58

Figure 80. Graph of compressive strength of all test specimens after 7 days................................59

Figure 81. Graph of compressive strength of all test specimens after 28 days...............................59

Figure 82. Graph of compressive strength of all test specimens after 90 days. .............................60

Figure 83. Compressive strength after 180 days..........................................................................61

Figure 84. Graph of strength activity index for all mixtures..........................................................63

Figure 85. Graph of expansion of concrete with fly ash. ………………………………………....65

Figure 86. Graph of expansion of concrete with Pozzolan J.............................................................66

Figure 87. Graph of expansion of concrete with Pozzolan S. ..........................................................66

Figure 88. Graph of test specimen 14-day expansions with different admixtures. ...........................67

Figure 89. Graph of heat of hydration for cement and two pozzolan materials.................................68

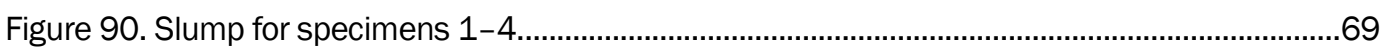

Figure 91. Slump for specimens 5-7. .................................................................................

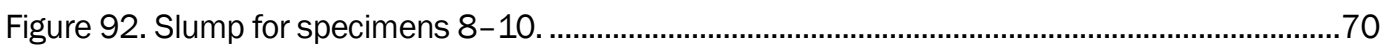

Figure 93. Bar chart of slump for all test mixtures........................................................................ 71

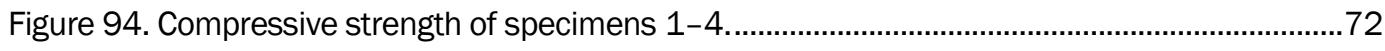

Figure 95. Compressive strength of specimens 5-7......................................................................

Figure 96. Compressive strength of specimens 8-10. ……................................................................73

Figure 97. Compressive strength of specimens 11-13............................................................. 74

Figure 98. Relationship between W/C ratio and strength for 20\% pozzolan. ……........................... 74

Figure 99. Relationship between W/C ratio and strength for $30 \%$ pozzolan. ....................................75

Figure 100. Strength increase for specimens 1-4 ..................................................................75

Figure 101. Strength increase for specimens 5-7.................................................................. 76

Figure 102. Strength increase for specimens 8-10......................................................................

Figure 103. Strength increase for specimens 11-13. .....................................................................7

Figure 104. Activity index for specimens 1-4............................................................................

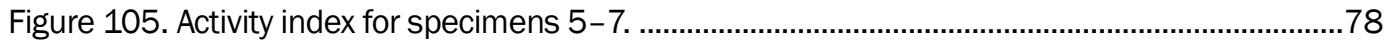

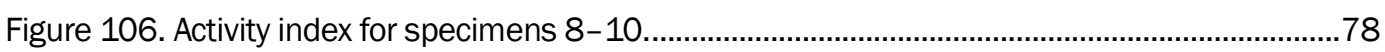

Figure 107. Activity index for specimens 11-13.............................................................................79

\section{Tables}

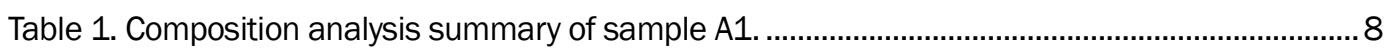

Table 2. Composition analysis summary of sample S. .................................................................

Table 3. Composition analysis summary of sample R2 ………………………………………....10

Table 4. Mix proportions of compressive specimens used in initial testing......................................20

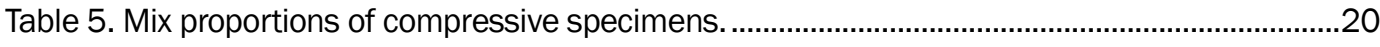

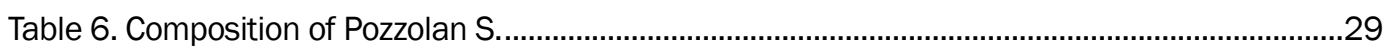


Table 7. Composition of Pozzolan G.

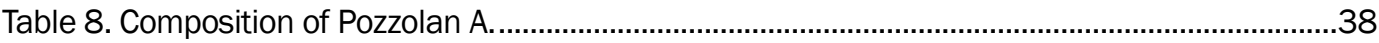

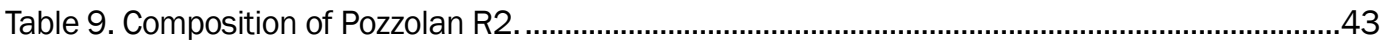

Table 10. Composition of Pozzolan R1 ............................................................................................44

Table 11. Summary of compressive testing for all mortar cubes containing pozzolan.....................46

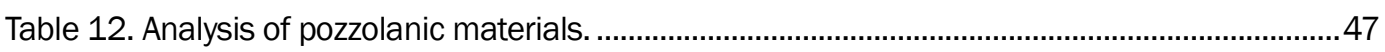

Table 13. Grain size distribution of pozzolanic materials. .................................................................48

Table 14. Chemical composition of Portland cement. ..........................................................................49

Table 15. Particle size distribution of Portland cement......................................................................49

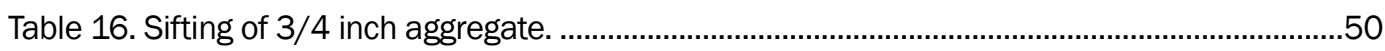

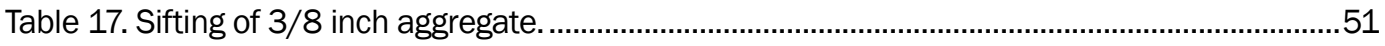

Table 18. Grain size distribution of basalt aggregate.......................................................................52

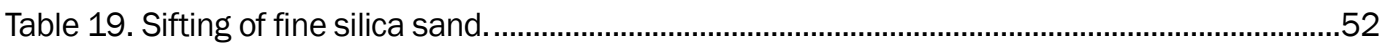

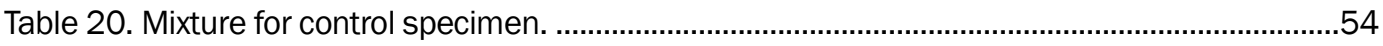

Table 21. Mixture for specimen with 10\% pozzolan. ..............................................................................55

Table 22. Compressive strength of control and test specimens with fly ash....................................55

Table 23. Compressive strength of test specimens with Pozzolan J....................................................56

Table 24. Compressive strength of test specimens with Pozzolan S1...............................................57

Table 25. Compressive strength of specimens with Pozzolan S2 ......................................................58

Table 26. Compressive strength of all test specimens after 7 days. ...............................................58

Table 27. Compressive strength of all test specimens after 28 days. ...............................................59

Table 28. Compressive strength of all test specimens after 90 days.................................................60

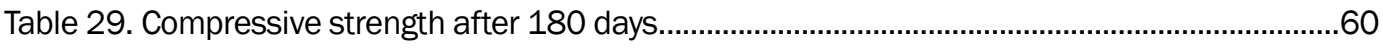

Table 30. Strength activity index with different pozzaolanic materials...............................................62

Table 31. ASTM C1260 Aggregate grading requirements...............................................................64

Table 32. Expansion of concrete with fly ash. ...................................................................................65

Table 33. Expansion of concrete with Pozzolan J. ................................................................................65

Table 34. Expansion of concrete with Pozzolan S. ...........................................................................66

Table 35. Test specimen 14-day expansions with different admixtures. ...........................................67

Table 36. Heat of hydration for cement and two pozzolan mixtures....................................................68

Table 37. Slump of specimens with varying amounts of pozzolan......................................................69

Table 38. Strength and activity index of specimens with varying amounts of pozzolan...................72

Table 39. ASTM requirements for fly ash and silica fume. ................................................................80

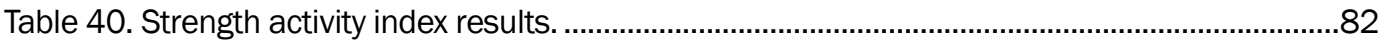

Table 41. Density, fineness, dry shrinkage, and volume results.......................................................82

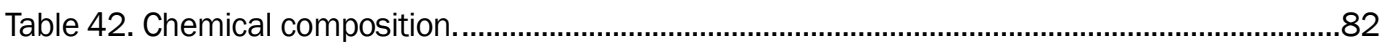

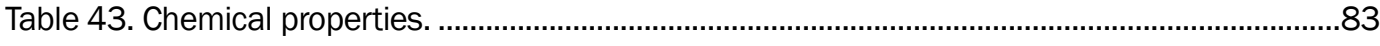

Table 44. Comparison between pozzolan physical properties and ASTM requirements. ..................83

Table 45. Comparison between pozzolan chemical properties and ASTM requirements.................84 


\section{Preface}

This study was conducted for the US Army Corps of Engineers (USACE) under the authority of the Engineer Research and Development Center Long-Term Training Program during a sabbatical for Dr. Ghassan AlChaar at King Saud University, Riyadh, Saudi Arabia, J anuary - J uly 2008. Taeser Aref Abomkdeb sponsored the research and provided partial funding under a King Saud University project entitled "Enhancing Concrete's Properties and Performance By Using Natural Pozzolan.” The USACE technical proponent for this investigation was the Directorate of Military Programs, CEMP-CI-P.

The work was executed under the supervision of the Materials and Structures Branch (CF-M) of the Facilities Division (CF), US Army Engineer Research and Development Center - Construction Engineering Research Laboratory (ERDC-CERL). At the time of publication, Vicki Van Blaricum was Chief, CEERD-CF-M; L. Michael Golish was Chief, CEERD-CF; and Martin J . Savoie (CEERD-CV-ZT) was the Technical Director for Installations. The Deputy Director of ERDC-CERL was Dr. Kirankumar Topudurti and the Director was Dr. Ilker Adiguzel.

Some of the tests documented in this report were carried out in part at the Frederick Seitz Materials Research Laboratory Central Facilities, University of Illinois at Urbana-Champaign, which are partially supported by the US Department of Energy under grants DE-FG02-07ER46453 and DEFG02-07ER46471. The authors wish to thank Dr. Mauro Sardela for his assistance in the test setup.

COL Kevin J. Wilson is the Commander and Executive Director of ERDC, and Dr. J effery P. Holland is the Director. 


\section{Unit Conversion Factors}

\begin{tabular}{|c|c|c|}
\hline Multiply & By & To Obtain \\
\hline atmosphere (standard) & 101.325 & kilopascals \\
\hline bars & 100 & kilopascals \\
\hline cubic feet & 0.02831685 & cubic meters \\
\hline cubic inches & 1.6387064 E-05 & cubic meters \\
\hline cubic yards & 0.7645549 & cubic meters \\
\hline degrees Fahrenheit & $(\mathrm{F}-32) / 1.8$ & degrees Celsius \\
\hline feet & 0.3048 & meters \\
\hline foot-pounds force & 1.355818 & joules \\
\hline inches & 0.0254 & meters \\
\hline microinches & 0.0254 & micrometers \\
\hline microns & $1.0 \mathrm{E}-06$ & meters \\
\hline pounds (force) & 4.448222 & newtons \\
\hline pounds (force) per square foot & 47.88026 & pascals \\
\hline pounds (force) per square inch & 6.894757 & kilopascals \\
\hline pounds (mass) & 0.45359237 & kilograms \\
\hline slugs & 14.59390 & kilograms \\
\hline square feet & 0.09290304 & square meters \\
\hline square inches & 6.4516 E-04 & square meters \\
\hline yards & 0.9144 & meters \\
\hline
\end{tabular}




\section{Introduction}

\subsection{Background}

Pozzolan is a siliceous material that can be used as an inexpensive substitute for cement in mortar mixtures. Some forms of it occur naturally and others are manmade. Pozzolan participates in a cementitious reaction with calcium hydroxide (i.e., lime) and other alkalis. The use of pozzolan with lime in masonry construction dates back to prehistoric antiquity.

Pozzolans are effective at lowering the mortar's heat of hydration, which improves its workability and durability. It also resists both sulfate and alkali-silica reactions, which makes it beneficial to use in large concrete projects such as bridges and dams (Gibbons 1997).

There are five major sources of pozzolan. Naturally occurring pozzolan deposits, an ashlike product of volcanic activity, can be found in Europe and the Middle East, among other regions. This type of pozzolan is very suitable for use in concrete in wet conditions. Pozzolan also can be derived from fired and crushed clay, such as bricks, and this variety is more durable than volcanic pozzolan. Furnace slag from industrial processes such manufacturing steel can also take the form of a pozzolan, and this type is currently used as a concrete admixture. Another type is organic ash, produced by burning coal or lime, but it is weaker than the other varieties and is generally not suitable for brick-and-mortar construction. Finally, some pozzolans have been produced by crushing rock and sand, and these have been used in mortars throughout history but are not commonly used today (Gibbons 1997).

Most pozzolans are plentiful and, because current uses for them are limited, they represent a potential source of inexpensive construction material. Some pozzolans can be processed into a material with characteristics similar to Portland cement, so it is feasible that a significant portion of cement in a concrete mixture may be replaced by pozzolan. This study explored the properties of concrete mixes after the addition of various pozzolan specimens. 


\subsection{Objective}

The objective of this study was to investigate the feasibility and effectiveness of using naturally occurring pozzolan materials as an additive or substitute for cement in concrete mixtures.

\subsection{Approach}

The first series of controlled laboratory investigations and analyses was performed using five samples of volcanic pozzolan selected from four different locations in the Governorate of Swaida, in southern Syria.

The sample from the Shehan volcanic mountain, called Pozzolan S in this study, consists of well burnt lightweight, glossy black porous sand that is free of dust and foreign materials. It was collected within 1 mile of the volcanic vent. A sample collected near Shehan, from Ghrara Heights (Pozzolan G), is similar to Pozzolan S but less pure. A third type of pozzolan collected in the area, near Ardh, appears to have constituents similar to the first two samples, but is found in the form of rocks instead of sand. Its color is gray and the texture is not glossy like Pozzolan S and G, appearing to have been less well burnt during formation. It is referred to as Pozzolan A in this study. Finally, samples found near Rsas are designated as Pozzolan R. Two specimens of this red-colored pozzolan were collected-Pozzolan R1 is fine-grained and Pozzolan R2 is coarse-grained.

In this first test series, the Pozzolans were used as both an additive and substitute for cement in Type M mortar, which is designed for a compressive strength of 2,500 psi. Type M mortar is typically blended in a volume ratio of 1.0 parts Portland cement, 0.25 parts lime, and 3.25 parts sand. Because Pozzolan S and Pozzolan G were considered to be chemically identical except for impurities mixed in with the sample of the latter, Pozzolan $\mathrm{S}$ was used to represent both samples for purposes of experimentation. The chemical compositions of Pozzolans S, G, and A were analyzed using $x$-ray diffraction (XRD) to examine similarities among the three. The purposes of this test series were to determine the physical and chemical properties of the four cementitious pozzolans and to identify correlations between the mechanical properties of the experimental mixes and a control mix using Type I Portland cement. Compression test results were the metric for determining the suitability of a pozzolan as a Portland cement substitute in mortar. 
The second experimental series subjected commercially specified Class $F$ fly ash and three different samples of natural pozzolan to the following laboratory tests: chemical composition, strength activity index, expansion for alkali-silica reaction (ASR), heat of hydration, fineness, autoclave expansion, dray shrinkage, loss on ignition, moisture content, and $\mathrm{pH}$. The samples used in this series were Pozzolan J , collected from a site in J ordan; Pozzolan S1, from Saudi Arabia; and Pozzolan S2, from South Africa. These latter two samples should not be confused with Pozzolan $S$ as described above, which is the volcanic sample from Shehan, in Syria, used in the first series of tests. The purposes of this test series were to assess the effectiveness of the test pozzolans in controlling the ASR and reducing the heat of hydration when used as cement-replacement materials. Chemical composition results were the metric for this aspect of testing.

\subsection{Literature review}

A literature search was conducted to review studies addressing concrete degradation caused by the reaction of alkali aggregates in cement and excessive heat of hydration during the curing process.

Alkalis in cement (typically sodium and potassium oxide) can react with aggregates containing silica or carbonate mineral constituents, particularly for concrete used in warm, moist environments. In cured cement these reactions lead to different types of expansion that cause harmful effects such as internal cracking, surface cracking, and aggregate pop-outs. This expansion in turn may cause dislocation, distortion, or misalignment of structural elements (Dolar-Mantuani 1983).

Two principal deleterious reactions between aggregates and cement have been identified: the alkali-silica reaction (ASR) and the alkali-carbonate reaction. In addition to the ASR, some references also identify a related alkali-silicate reaction in order to distinguish a difference in expansion mechanism between alkali and silica versus alkali and silicate (GrattanBellew 2003).

Classic research by Stanton (1940) diagnosed ASR failure as being due to expansion caused by a chemical reaction between the alkalis contained in the cement paste and certain reactive forms of silica within the aggregate. Stanton identified opal and chert as the common forms of reactive silica. 
For cracking and expansion to result from the ASR, the following combination of conditions is normally required (Hobbs 1988):

1. significant quantity of reactive silica

2. reactive silica within a critical range of proportions

3. available alkalis above a critical level

4. water from an external source.

Suitable precautions must be taken to minimize or eliminate the probability of harmful expansion and cracking, including:

1. decreasing the amount of reactive aggregate; it may be economical to use some proportion of local reactive aggregate, rather than using all imported aggregates (Björk 2002)

2. using low-alkali cement that meets the optional requirement for low alkali content of ASTM C150

3. using mineral admixtures such as pozzolan or blended cement where low-alkali cement is not readily available (Lane et al.; Wang and Gillott 1993; Thomas and Innis 1998)

4. decreasing the availability of water to a level where the relative humidity in the concrete pores falls below about 85-90\%, at which no adverse expansion occurs. 


\section{Scanning Electron Microscopy Tests of Pozzolan Composition}

Pozzolan composition was investigated using scanning electron microscopy (SEM), which produces images by scanning a focused electron beam across the specimen surface. In the most common mode, the low-energy secondary electrons emitted are detected and used to modulate the brightness of a synchronously scanned cathode ray tube, but other signals also can be detected. X-rays allow both a qualitative and quantitative determination of the elements present in the selected portion of the specimen. High-energy backscattered electrons can be separated and used for image formation. Backscattering efficiency is a function of atomic weight, so the image reveals compositional variations due to the average atomic number.

Attached to the SEM scanner was an energy-dispersive spectroscopy (EDS) unit made by EDAX (Mahwah, NJ 07430). Some electrons from the SEM beam bounce off the sample and are detected by the SEM detector to produce images. Other electrons penetrate the specimen and cause x-rays to be emitted, which are detected by the EDS sensor. The x-ray produces a unique signature for each different element, so the x-ray energies emitted provide information that identify chemical composition. Pozzolans A, S, and R2 (see section 1.3) were tested. The SEM images range between X500 and X10,000 in magnification. They are shown in Figures 1- 13.

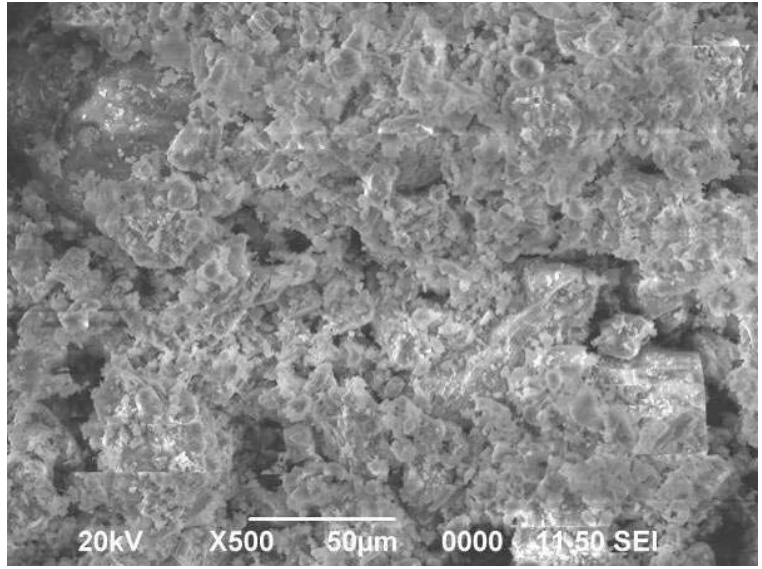

Figure 1. Sample A1 in the SEM, $20 \mathrm{kV}$, and X500.

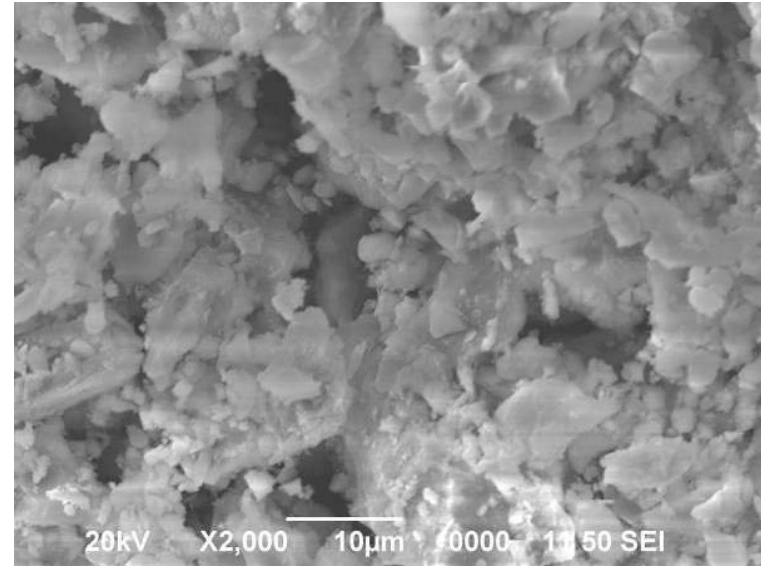

Figure 2. Sample A1 in the SEM, $20 \mathrm{kV}$, and X2,000. 


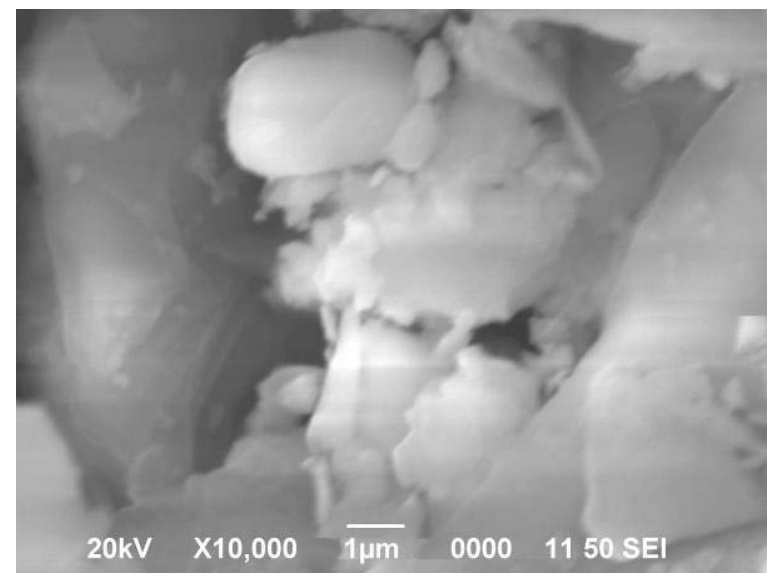

Figure 3. Sample A1 in the SEM, $20 \mathrm{kV}, \mathrm{X10,000.}$

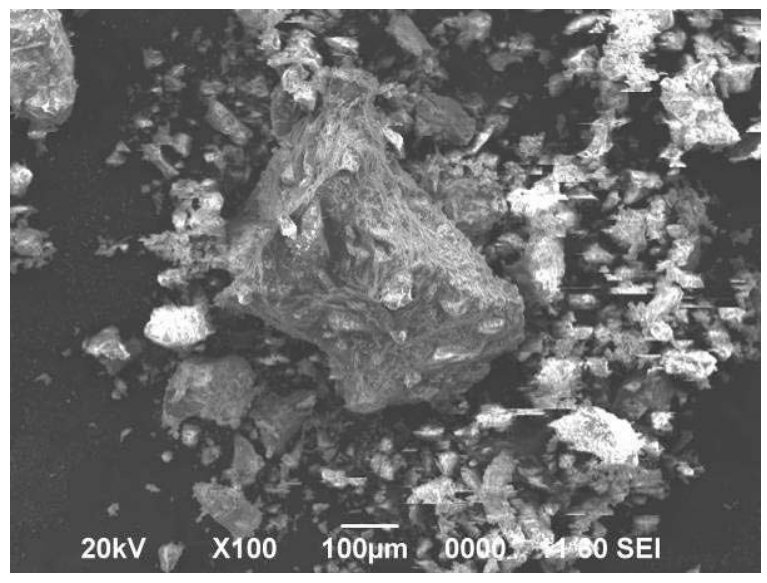

Figure 4. Sample B1 in SEM, 20 kV, X100.

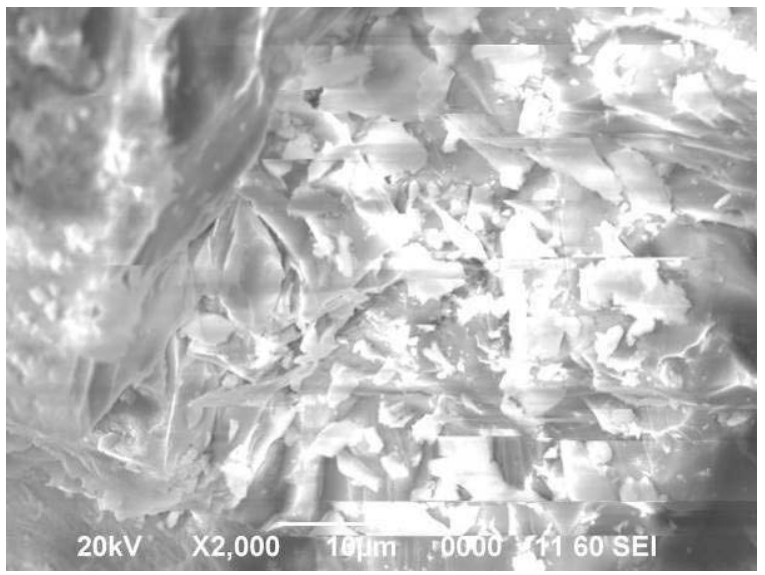

Figure 6. Sample S in SEM, 20 kV, X2,000.

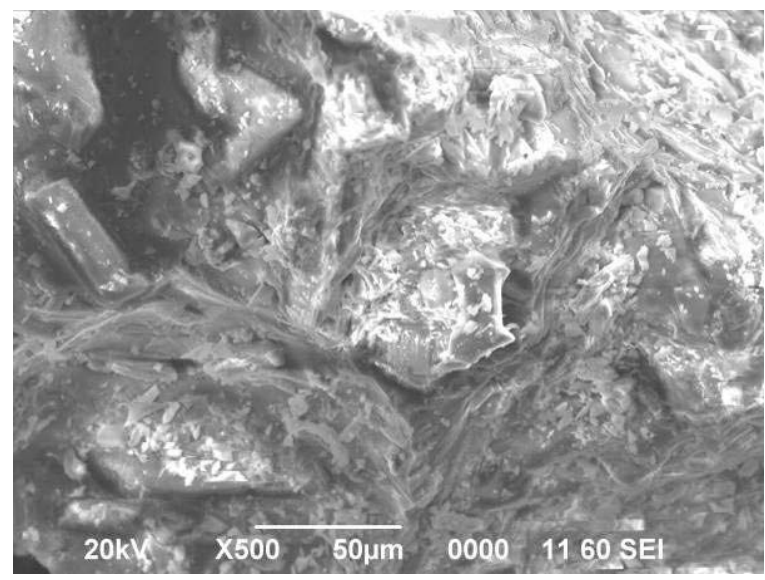

Figure 5. Sample S in SEM, 20 kV, X500.

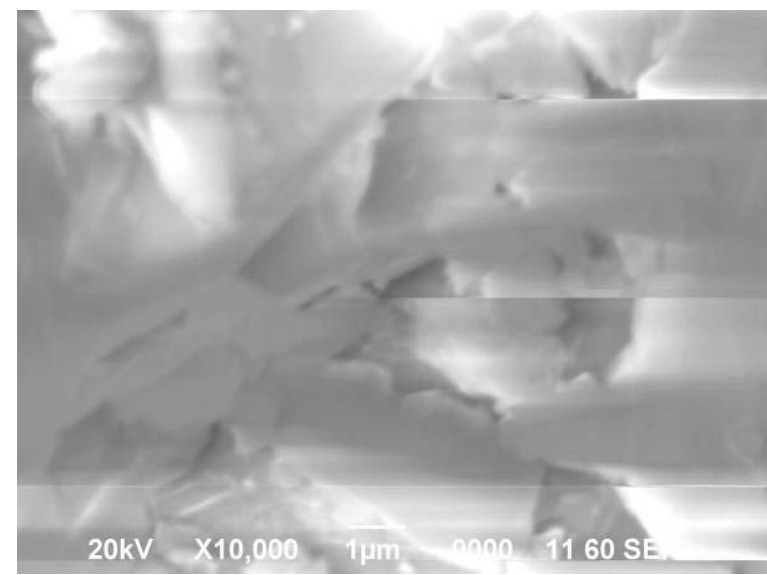

Figure 7. Sample $S$ in SEM, 20 kV, X10,000. 


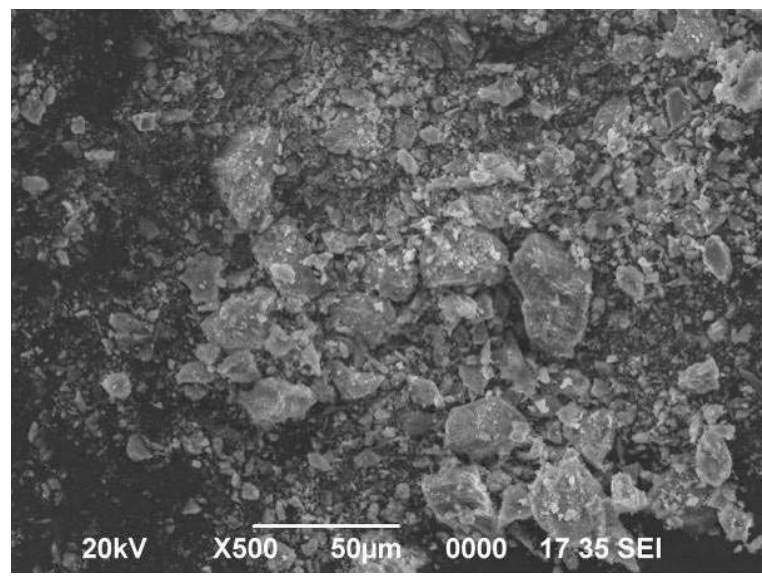

Figure 8. Sample R2 in SEM, 20 kV, X500.

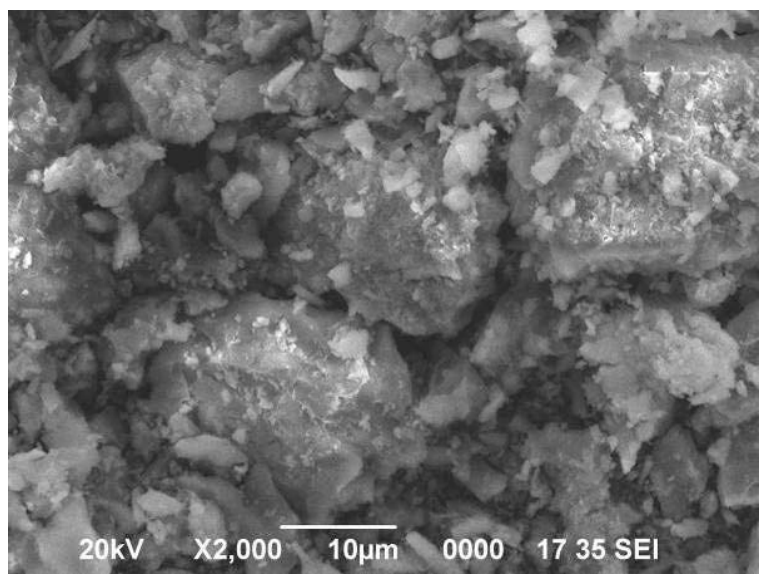

Figure 10. Sample R2 in SEM, 20 kV, X2,000.

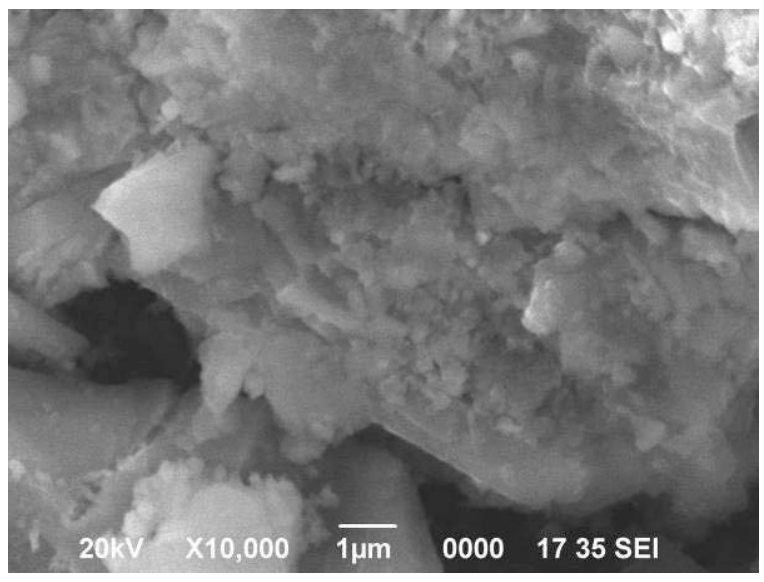

Figure 12. Sample R2 in SEM, 20 kV, X10,000.

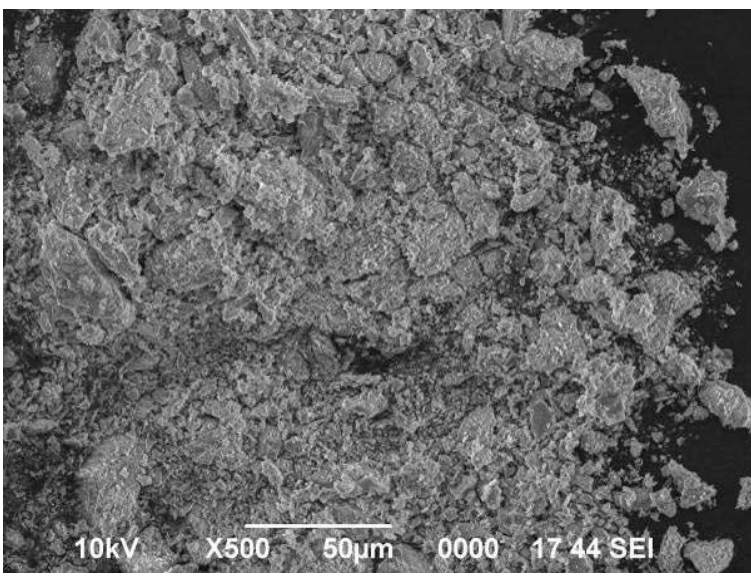

Figure 9. Sample R2 in SEM, 10 kV, X500.

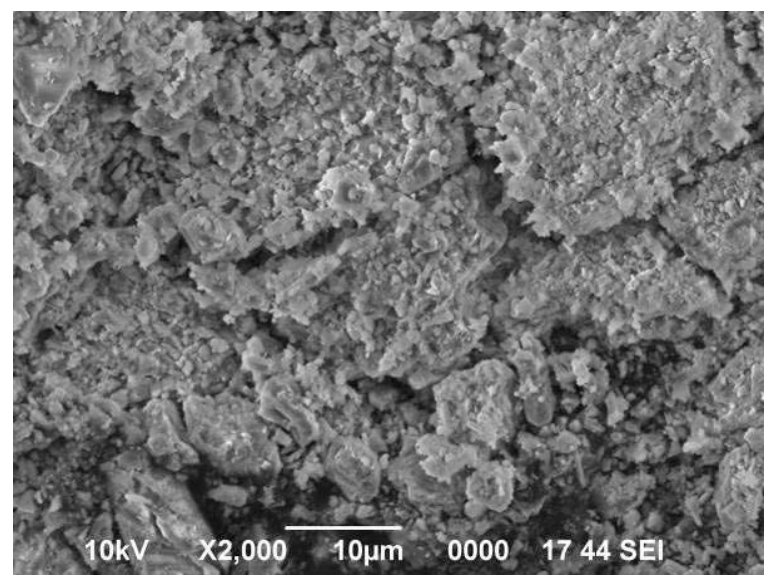

Figure 11. Sample R2 in SEM, 10 kV, X2,000.

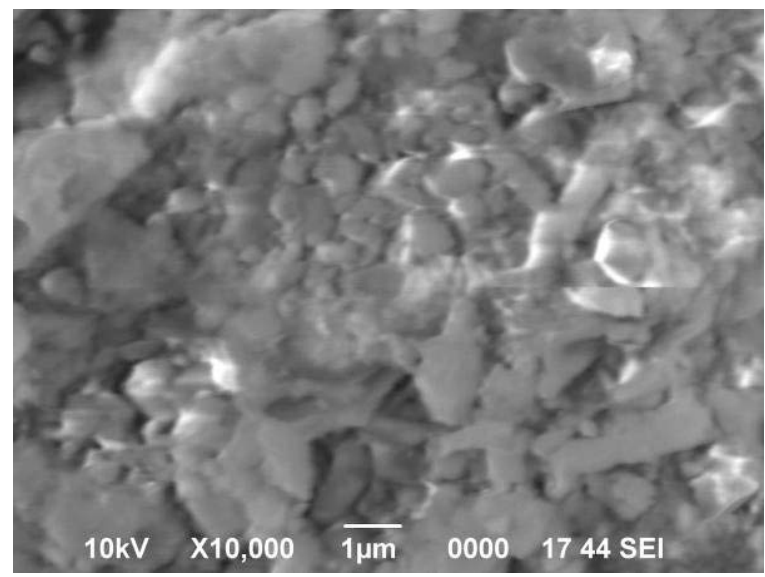

Figure 13. Sample R2 in SEM, 10kV, X10,000.

Chemical analysis results of the three samples are shown in Tables 1 - 3 and Figures 14 - 16. 
Table 1. Composition analysis summary of sample A1.

\begin{tabular}{|l|l|l|l|l|l|l|l|l|l|}
\hline & O K & NaK & MgK & AlK & SiK & K K & CaK & TiK & FeK \\
\hline $\begin{array}{l}\text { Weight \% by } \\
\text { Element }\end{array}$ & 47.56 & 2.78 & 2.21 & 12.29 & 15.7 & 1.26 & 6.2 & 2 & 10 \\
\hline $\begin{array}{l}\text { Atomic \% by } \\
\text { Element }\end{array}$ & 64.53 & 2.62 & 1.97 & 9.89 & 12.13 & 0.7 & 3.36 & 0.91 & 3.89 \\
\hline K-Ratio & 0.1483 & 0.009 & 0.01 & 0.0694 & 0.0949 & 0.011 & 0.0566 & 0.0172 & 0.0875 \\
\hline $\begin{array}{l}\text { Matrix } \\
\text { Corrections }\end{array}$ & 1.0398 & 0.9731 & 0.9975 & 0.9682 & 0.9964 & 0.9457 & 0.968 & 0.884 & 0.8798 \\
\hline Method & 0.2996 & 0.3304 & 0.4537 & 0.5802 & 0.6062 & 0.9083 & 0.9356 & 0.9571 & 0.9946 \\
\hline ZAF & 1.0006 & 1.003 & 1.0054 & 1.0053 & 1.0011 & 1.0146 & 1.0077 & 1.0121 & 1 \\
\hline $\begin{array}{l}\text { Net } \\
\text { Intensities }\end{array}$ & 112.62 & 9.6 & 10.98 & 75.08 & 95.75 & 7.64 & 35.55 & 8.63 & 25.19 \\
\hline $\begin{array}{l}\text { Background } \\
\text { Intensities }\end{array}$ & 5.32 & 10.97 & 10.53 & 9.89 & 6.74 & 4.09 & 3.82 & 3.56 & 2.63 \\
\hline
\end{tabular}

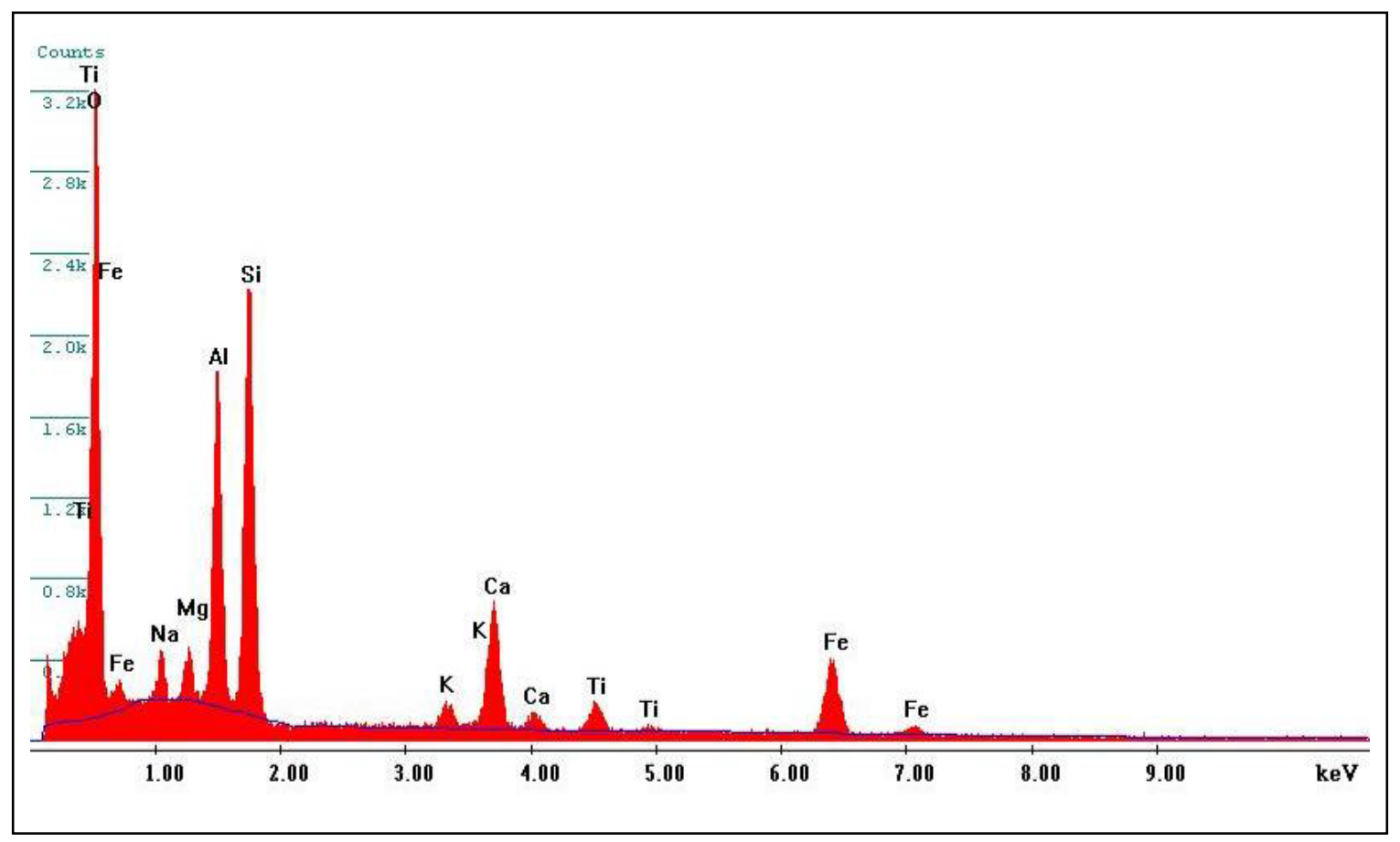

Figure 14. Plot of SEM/EDS results for sample A1. 
Table 2. Composition analysis summary of sample S.

\begin{tabular}{|l|l|l|l|l|l|l|l|l|l|l|}
\hline & $\mathrm{CK}$ & $\mathrm{OK}$ & $\mathrm{NaK}$ & $\mathrm{MgK}$ & $\mathrm{AlK}$ & $\mathrm{SiK}$ & $\mathrm{K} \mathrm{K}$ & $\mathrm{CaK}$ & $\mathrm{TiK}$ & $\mathrm{FeK}$ \\
\hline $\begin{array}{l}\text { Weight \% by } \\
\text { Element }\end{array}$ & 27.08 & 39.59 & 2.2 & 1.52 & 6.62 & 9.22 & 0.81 & 4.51 & 1.16 & 7.3 \\
\hline $\begin{array}{l}\text { Atomic \% by } \\
\text { Element }\end{array}$ & 39.22 & 43.04 & 1.66 & 1.08 & 4.27 & 5.71 & 0.36 & 1.96 & 0.42 & 2.27 \\
\hline K-Ratio & 0.065 & 0.096 & 0.008 & 0.0073 & 0.04 & 0.062 & 0.007 & 0.042 & 0.01 & 0.063 \\
\hline $\begin{array}{l}\text { Matrix } \\
\text { Corrections }\end{array}$ & 1.038 & 1.02 & 0.955 & 0.979 & 0.95 & 0.978 & 0.927 & 0.949 & 0.866 & 0.862 \\
\hline $\begin{array}{l}\text { (Method } \\
\text { ZAF) }\end{array}$ & 0.232 & 0.238 & 0.359 & 0.4924 & 0.626 & 0.688 & 0.955 & 0.974 & 0.984 & 1.006 \\
\hline & 1 & 1 & 1.002 & 1.0035 & 1.004 & 1.001 & 1.014 & 1.007 & 1.012 & 1 \\
\hline $\begin{array}{l}\text { Net } \\
\text { Intensities }\end{array}$ & 21.25 & 82.49 & 9.17 & 9.09 & 48.48 & 71 & 5.71 & 29.92 & 5.69 & 20.68 \\
\hline $\begin{array}{l}\text { Background } \\
\text { Intensities }\end{array}$ & 2.82 & 4.18 & 8.77 & 8.45 & 7.93 & 5.38 & 2.92 & 2.67 & 2.37 & 1.92 \\
\hline $\begin{array}{l}\text { Intensity } \\
\text { Errors }\end{array}$ & 1.97 & 0.93 & 4.55 & 4.52 & 1.33 & 1.03 & 4.8 & 1.6 & 4.58 & 1.93 \\
\hline
\end{tabular}

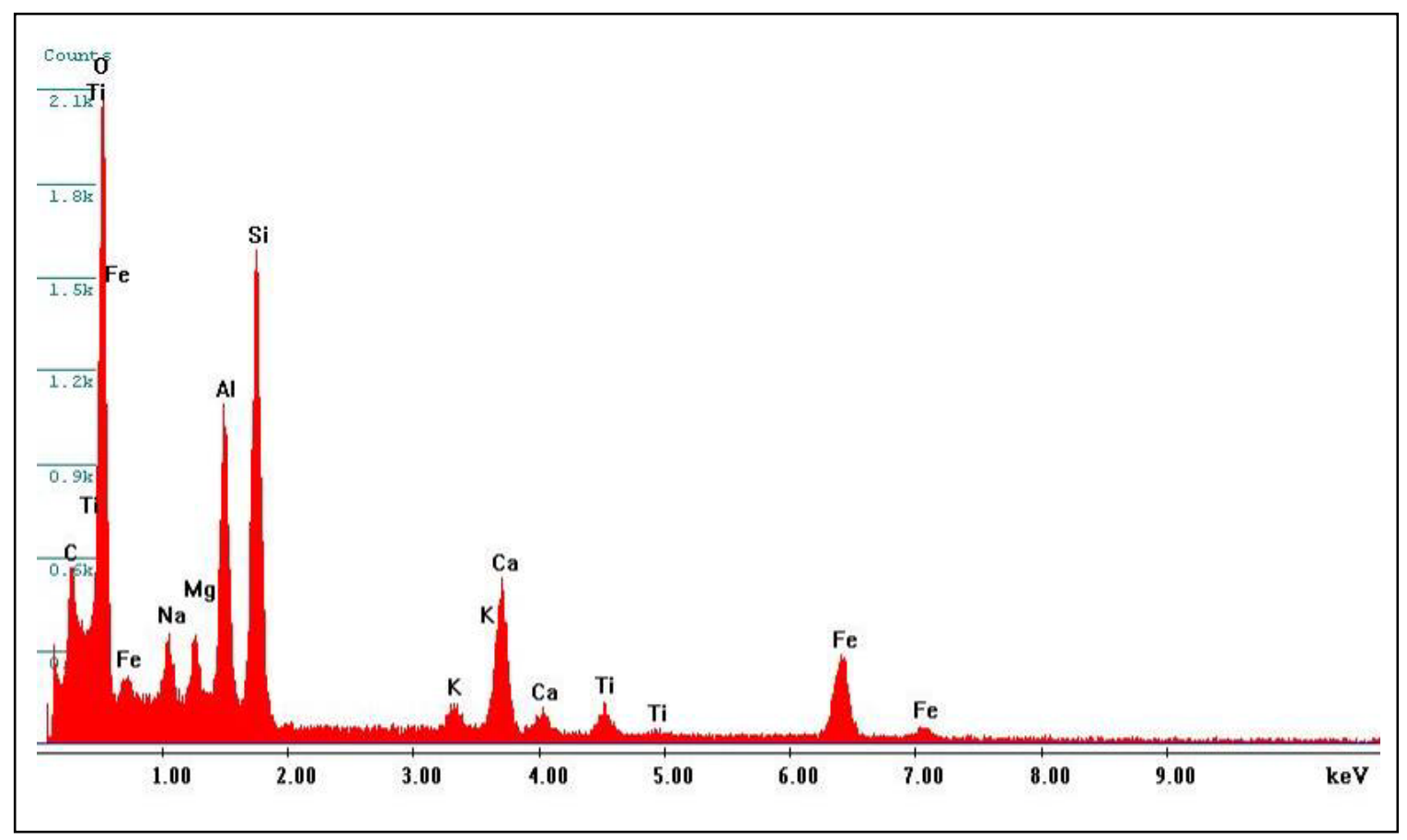

Figure 15. Plot of SEM/EDS results for sample S. 
Table 3. Composition analysis summary of sample R2.

\begin{tabular}{|l|l|l|l|l|l|l|l|l|l|l|}
\hline & O K & NaK & MgK & AlK & SiK & K K & CaK & TiK & V K & FeK \\
\hline $\begin{array}{l}\text { Weight \% by } \\
\text { Element }\end{array}$ & 48.84 & 3.44 & 3.5 & 9.78 & 15.39 & 0.91 & 7.54 & 2.04 & 0.19 & 8.37 \\
\hline $\begin{array}{l}\text { Atomic \% by } \\
\text { Element }\end{array}$ & 65.45 & 3.21 & 3.08 & 7.77 & 11.75 & 0.5 & 4.03 & 0.91 & 0.08 & 3.21 \\
\hline K-Ratio & 0.1478 & 0.0112 & 0.0158 & 0.0539 & 0.0944 & 0.008 & 0.069 & 0.0173 & 0.0016 & 0.073 \\
\hline $\begin{array}{l}\text { Matrix } \\
\text { Corrections }\end{array}$ & 1.0375 & 0.9709 & 0.9953 & 0.966 & 0.9942 & 0.9435 & 0.9657 & 0.8819 & 0.8631 & 0.8776 \\
\hline $\begin{array}{l}\text { (Method } \\
\text { ZAF) }\end{array}$ & 0.2916 & 0.3337 & 0.4528 & 0.5681 & 0.6163 & 0.9129 & 0.9409 & 0.9559 & 0.972 & 0.9938 \\
\hline & 1.0005 & 1.0029 & 1.0049 & 1.0053 & 1.0012 & 1.0167 & 1.0072 & 1.0099 & 1.0156 & 1 \\
\hline $\begin{array}{l}\text { Net } \\
\text { Intensities }\end{array}$ & 94.11 & 10.05 & 14.54 & 48.96 & 79.9 & 4.64 & 36.39 & 7.31 & 0.61 & 17.65 \\
\hline $\begin{array}{l}\text { Background } \\
\text { Intensities }\end{array}$ & 4.67 & 9.4 & 9.42 & 9.83 & 6.35 & 2.98 & 2.7 & 2.34 & 2.08 & 1.59 \\
\hline $\begin{array}{l}\text { Intensity } \\
\text { Errors }\end{array}$ & 0.8 & 3.96 & 2.95 & 1.25 & 0.89 & 5.2 & 1.32 & 3.51 & 26.56 & 1.92 \\
\hline
\end{tabular}

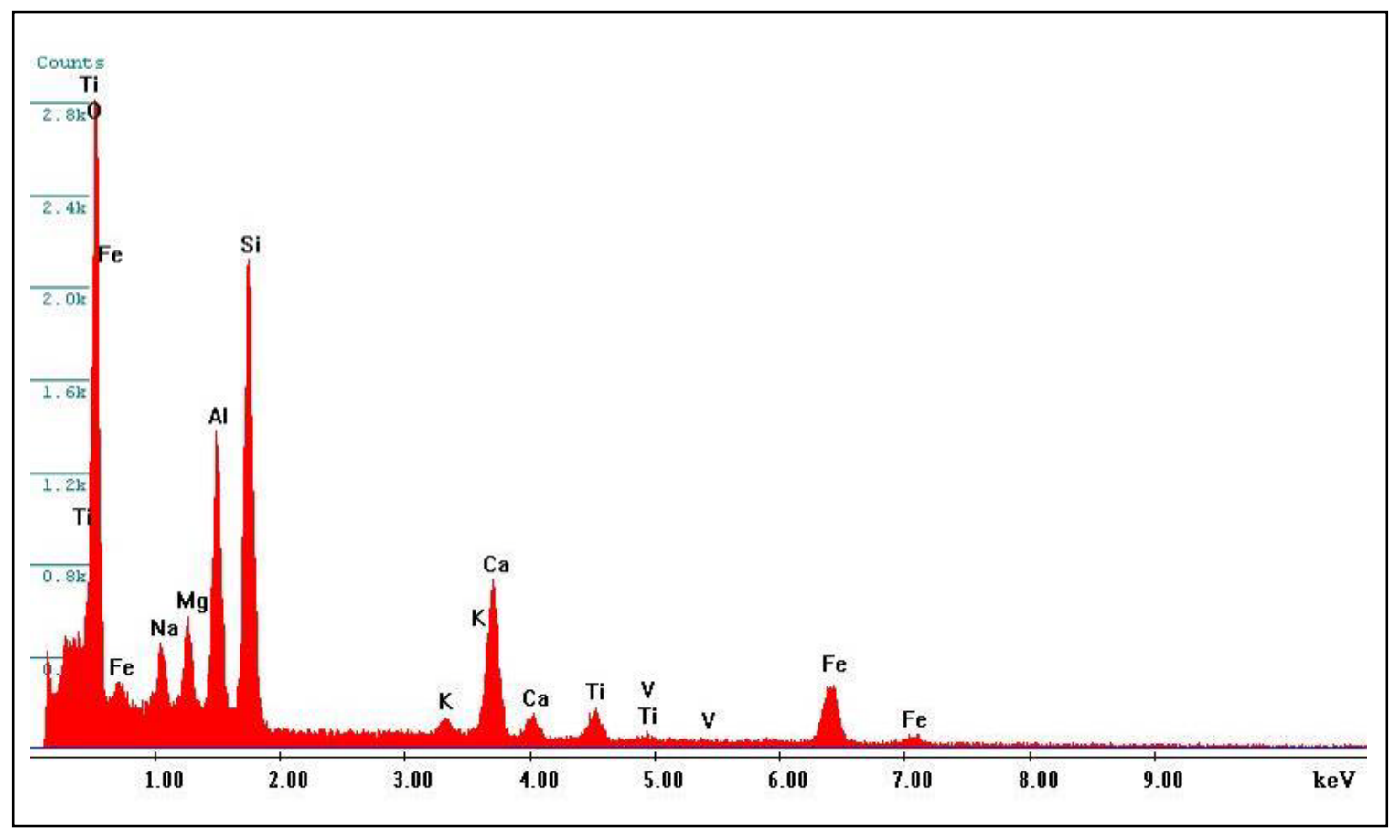

Figure 16. Plot of SEM/EDS results for sample R2. 


\section{Evaluation of Pozzolan as a Mortar Admixture}

\subsection{Overview}

The purpose of these evaluations was to investigate the suitability of natural pozzolan as a replacement for cement in concrete mortar mixes. The technical objective was to determine the best source of pozzolan for such use, and the ideal percentage to use in the mortar.

The chemical composition of three natural pozzolanic samples was determined through XRD analysis. In addition to these analyses, several additional tests needed to fully characterize the materials. These included compressive testing because compressive strength is a critical characteristic of concrete and masonry. Compressive testing was performed on specimens containing varying amounts and types of pozzolan.

The natural pozzolans investigated in this evaluation were

- Shehan (Pozzolan S), a dark black material that is the purest form found in nature

- Grara (Pozzolan G), very similar to Pozzolan S, but less pure

- Ardh (Pozzolan A), occurring in the form of rocks and not well burnt during formation

- Rsas (two types)

o coarse (Pozzolan R2) and

o fine (Pozzolan R1).

The source locations for these pozzolans, noted previously in section 1.3, are shown in Figures 17 - 20. All samples underwent chemical testing but only Pozzolans S, G, and A were subjected to compressive loading. The two specimens of Pozzolan $R$ were excluded from full analysis because this type is relatively rare and therefore does not have great potential for widespread use as a mortar additive. Also, the R1 specimens did not yield clear results due to its impurity, contributing to the decision to limit testing on Pozzolan R. 


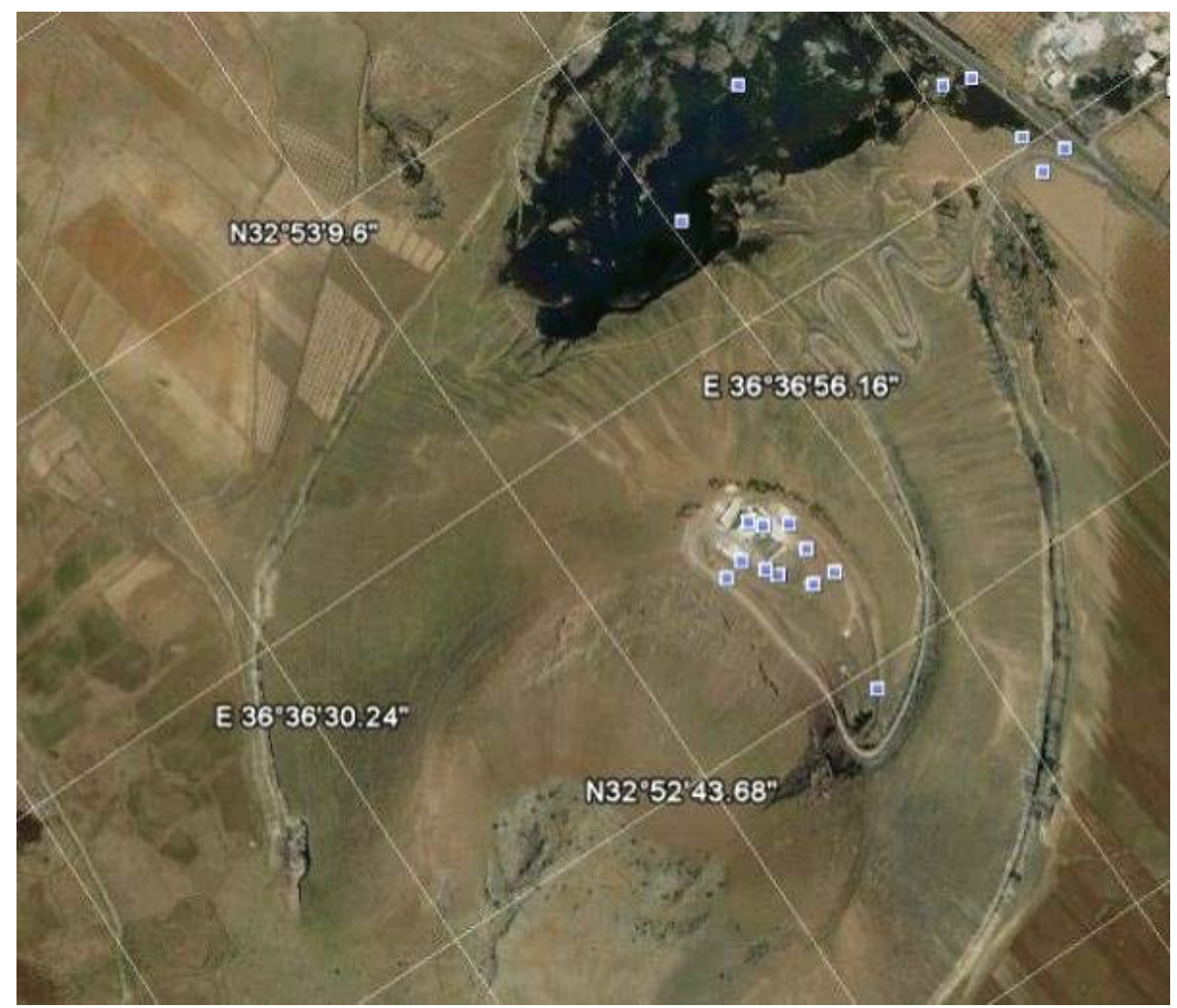

Figure 17. Satellite image of Shehan pozzolan with global positioning coordinates.

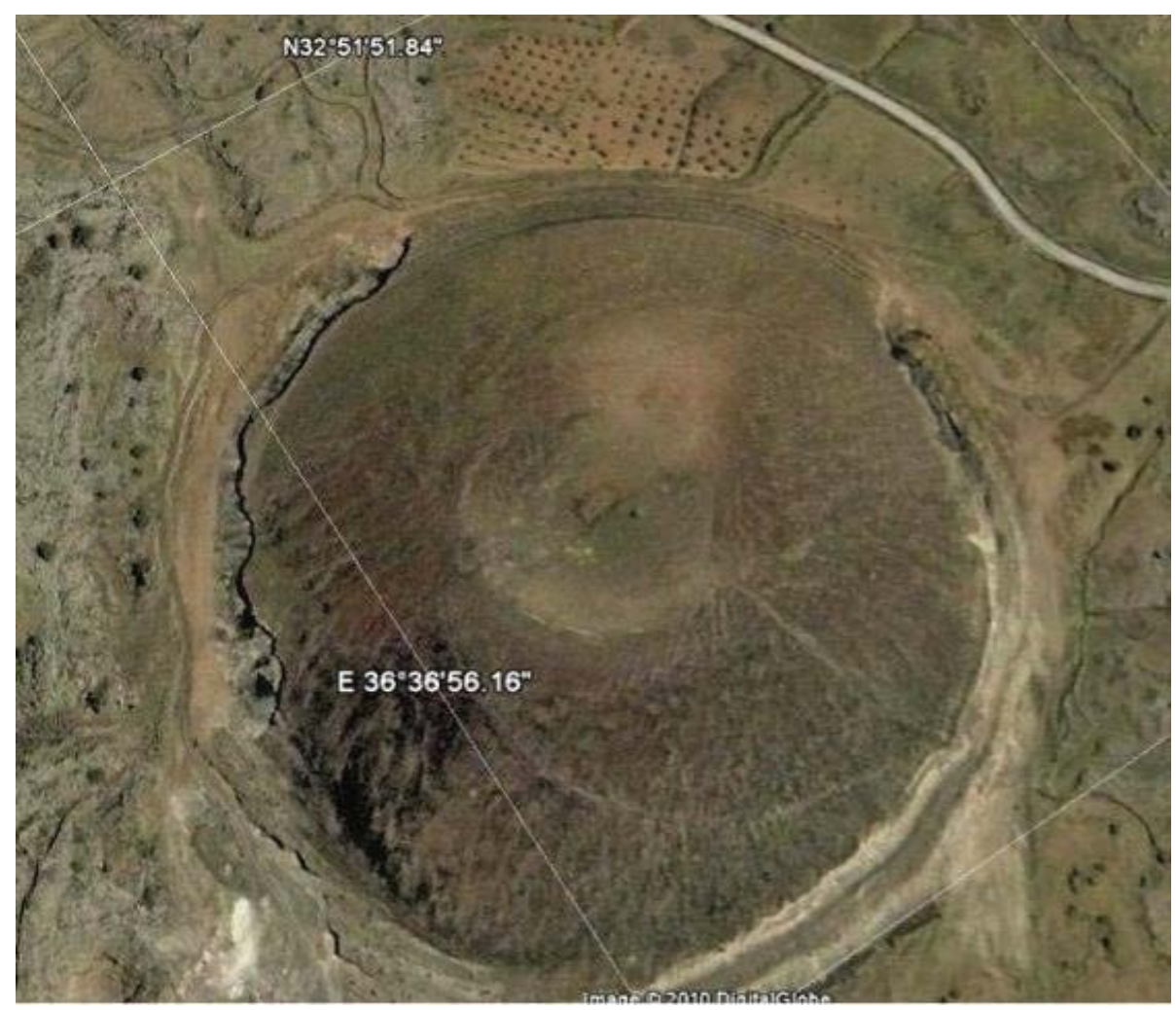

Figure 18. Satellite image of Grara pozzolan with global positioning coordinates. 


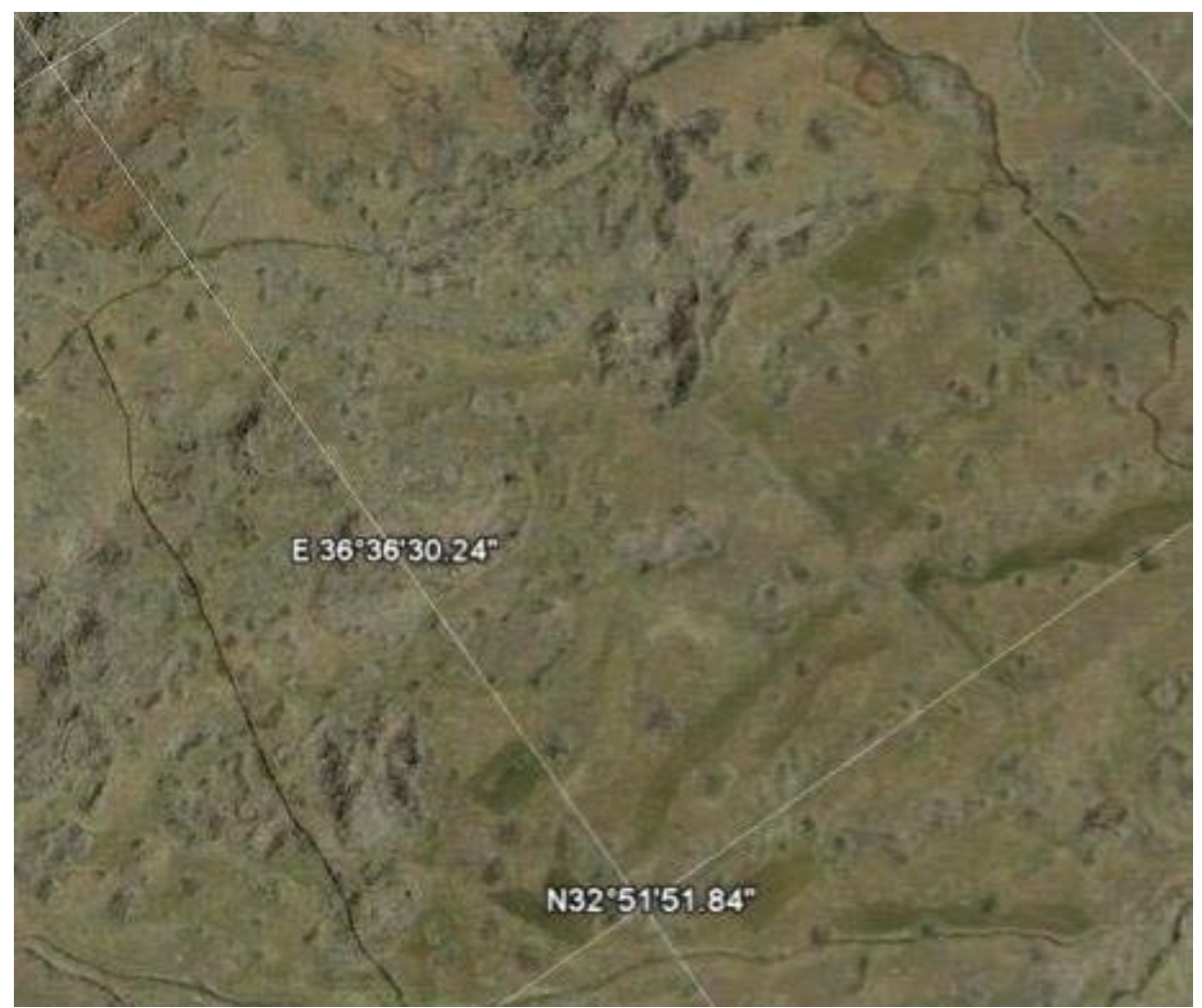

Figure 19. Satellite image of Ardh pozzolan with global positioning coordinates.

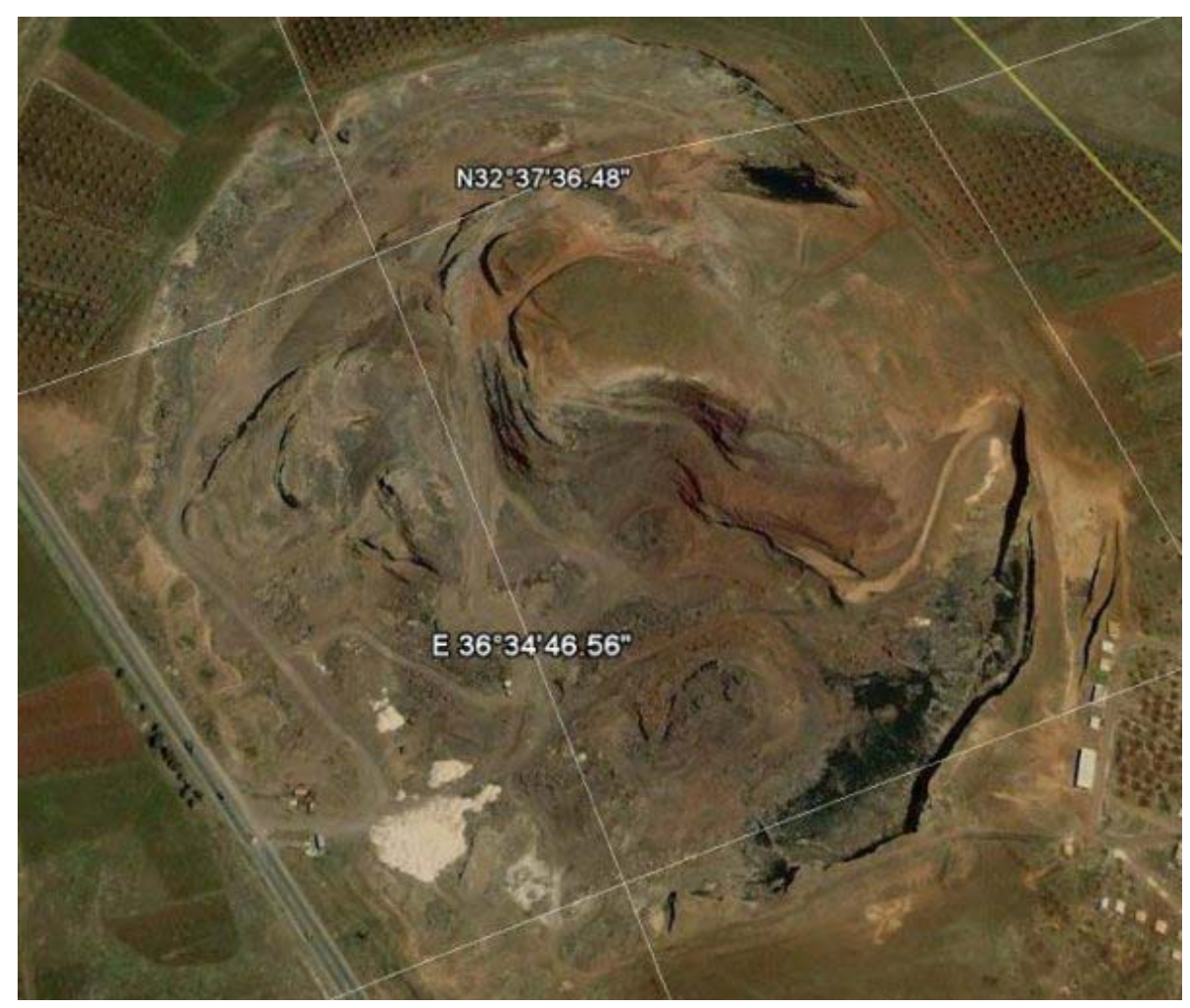

Figure 20. Satellite image of Rsas pozzolan with global positioning coordinates. 
There are several different classes of mortar, determined by the strength of the cementitious material. Types M, S, and N are the most common, listed in order of decreasing strength. The mixtures described below attempt to replicate Type $\mathrm{M}$ (compressive strength $=2,500 \mathrm{psi}$ ) using the various pozzolans. (Pozzolan S compressive strength $=1,800$ psi and Type $\mathrm{N}=750$ psi.) The experimental mixtures vary in terms of their aggregate ratios.

\subsection{Methodology}

\subsubsection{X-ray diffraction characterization}

The x-ray diffraction (XRD) machine is based on the Bragg-Brentano theta/ theta configuration shown in Figure 21. Several steps are required to achieve this test setup.

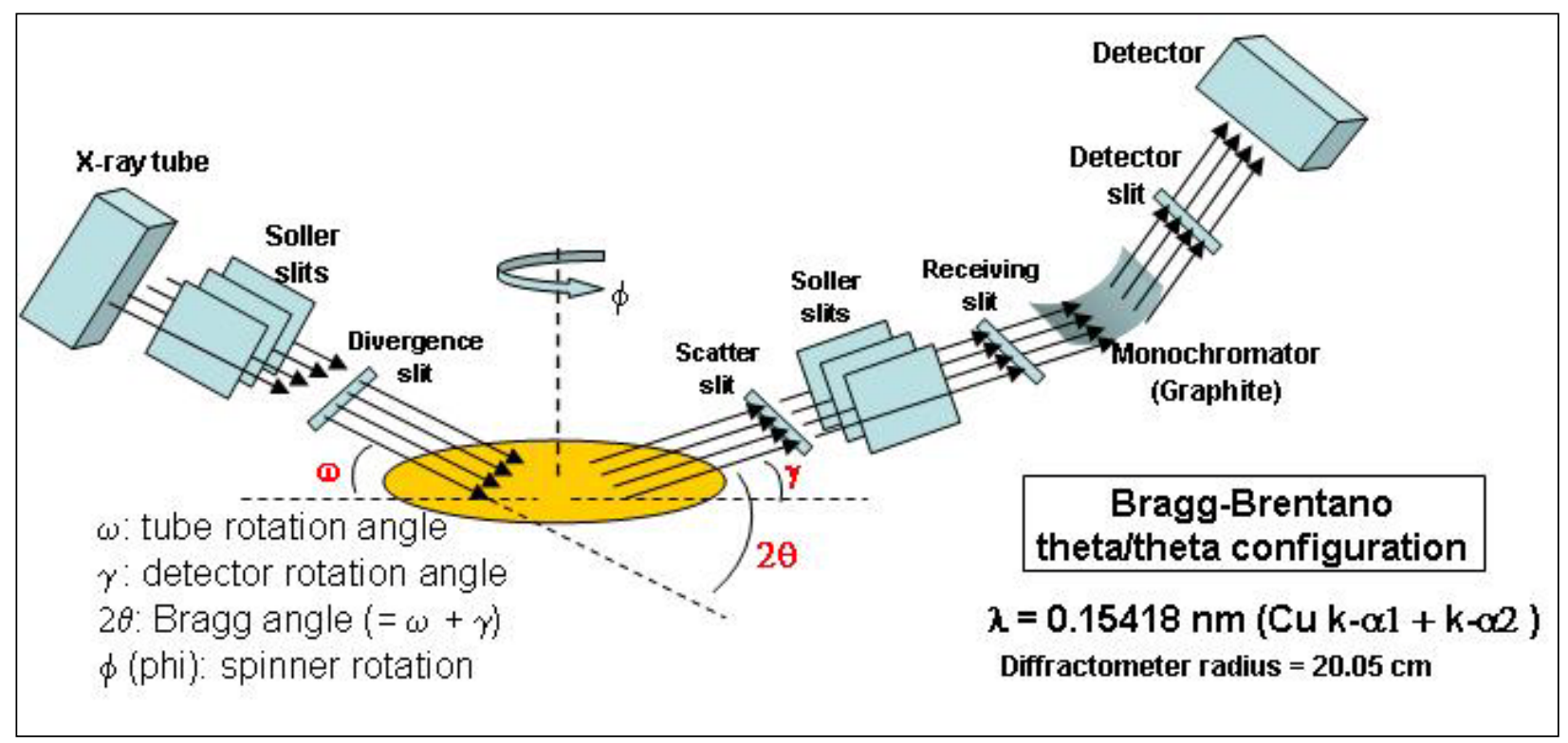

Figure 21. Schematic of setup with relevant angles indicated.

First a powder sample is prepared, ideally with particle sizes on the order of 100 microns or less. A finer material will yield more accurate results. These pozzolan samples used here required grinding into fines. First, a hammer was used to break the larger rocks down into sizes that were usable in the grinding equipment. Care was taken to capture all of the pozzolan on paper and to prevent its contamination with other dust in the lab. Next, the fractured material was placed in a large grinding jar containing several dozen non-porous spherical solids of various sizes designed for this purpose, as shown in Figure 22. The specimen jar was rotated on its side on a mechanized roller apparatus for several hours (Figure 23). The 
pozzolan materials were progressively crushed by the grinding stones to a power of sufficient fineness for the diffraction tests. Special care was taken to cleaning the crushing vessel between samples to prevent crosscontamination.

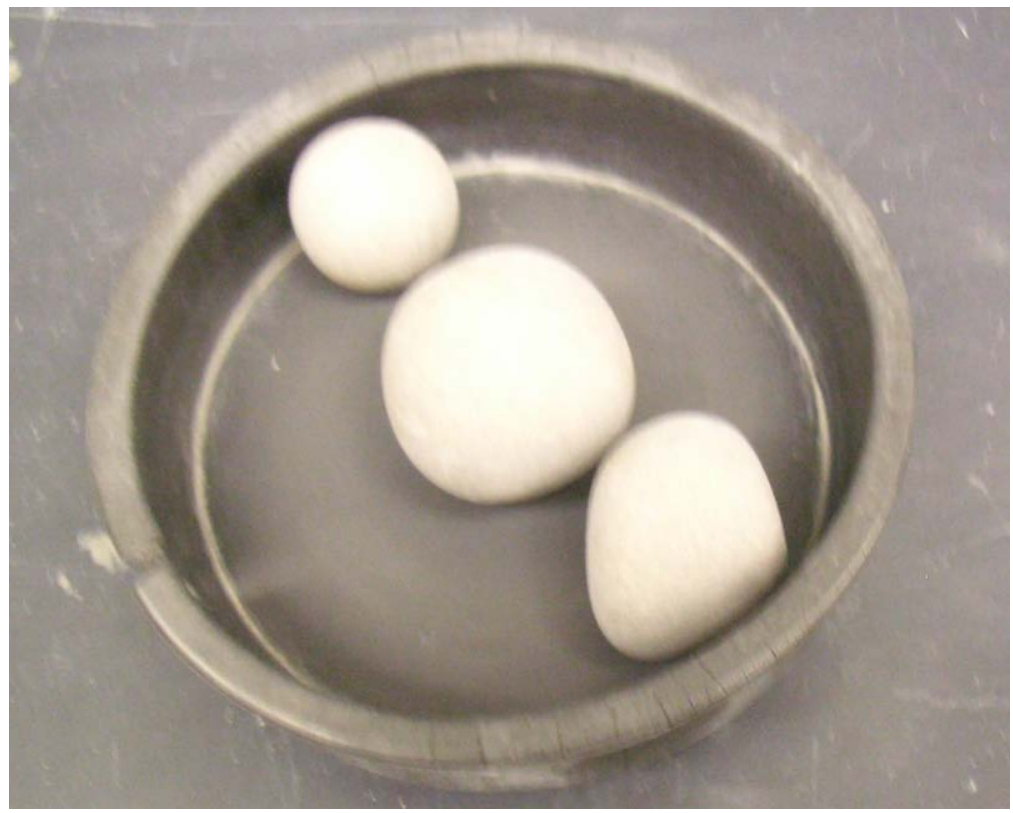

Figure 22. Typical stones used for mechanical crushing of pozzolan samples.

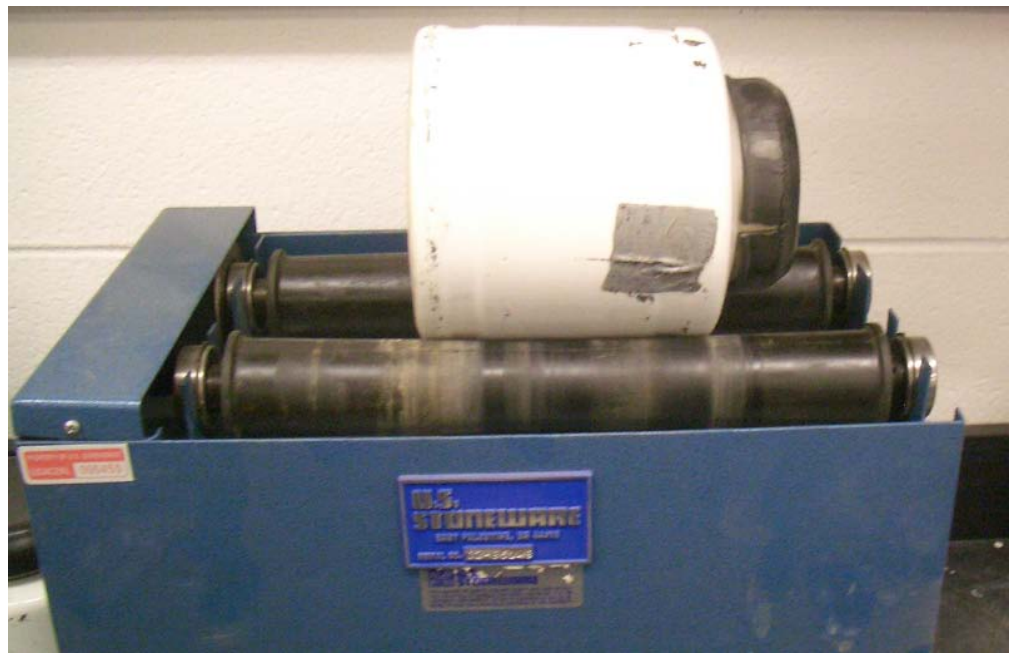

Figure 23. Jar and roller apparatus used to grind pozzolan samples.

Each sample was loaded in turn into a clear dish with a central depression measuring $1 \mathrm{~mm}$ deep, as shown in Figure 24. The dish is part of a sampleholding vessel that includes a spring and locking mechanism, shown apart and assembled in Figures 25 and 26, respectively. 


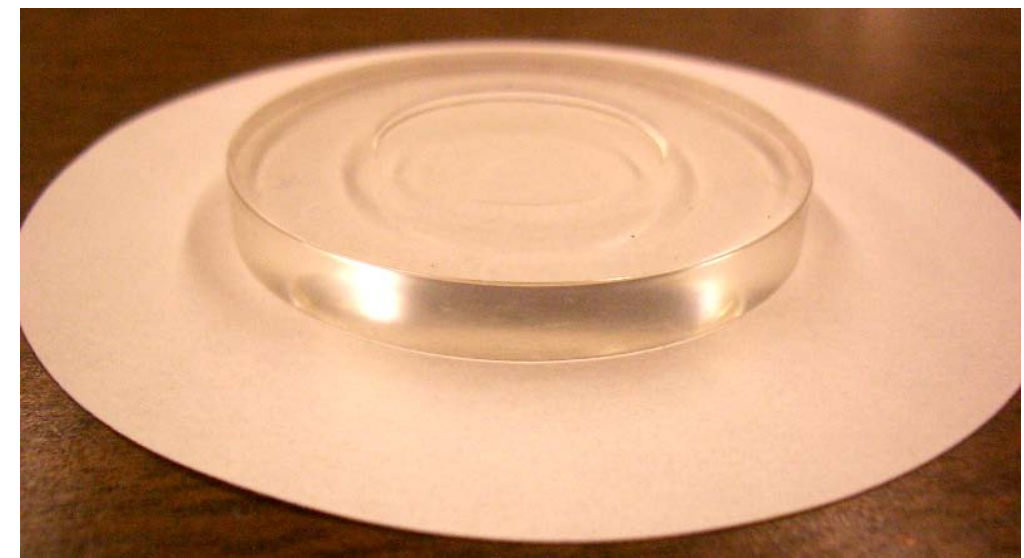

Figure 24. Dish where the powder sample is loaded.

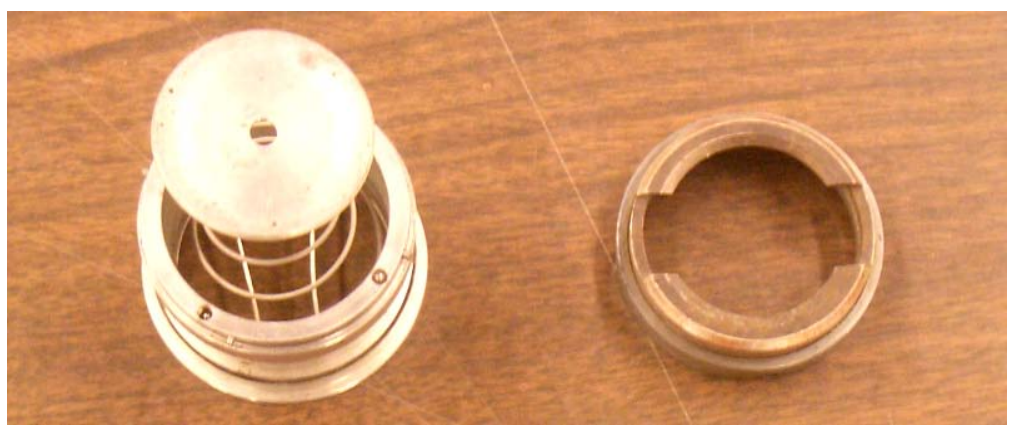

Figure 25. Spring and locking mechanism for the dish.

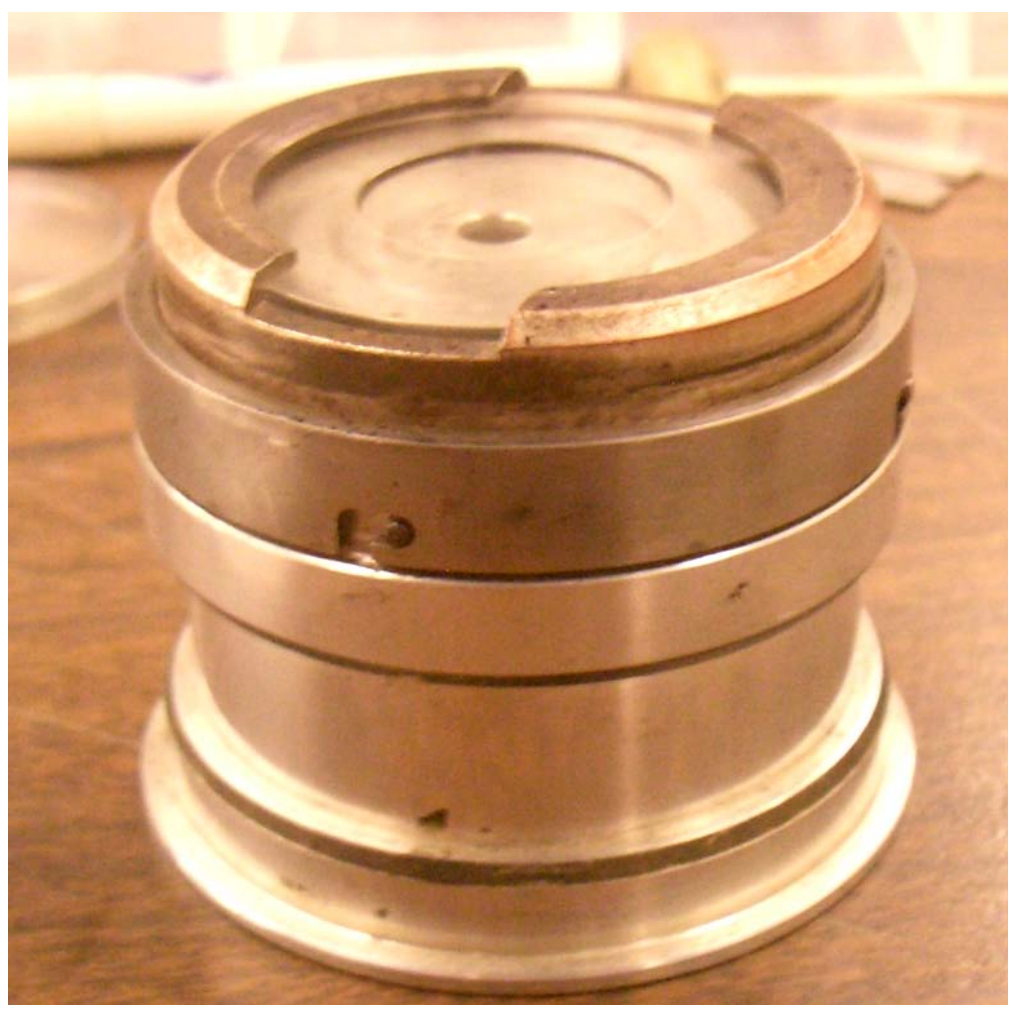

Figure 26. Assembled sample holder without sample loaded. 
Of the three sample-holding dishes available, the one measuring $25 \mathrm{~mm}$ in diameter was chosen. Using the smaller dishes, the incident $x$-rays hit the dish as well as the sample, skewing the measurement. The $25 \mathrm{~mm}$ dish is large enough so that all emitted x-rays hit the sample and produce usable data. Thus, it is beneficial to grind enough sample to fill the largest dish. It is also important that the powder fills the depression completely; too little or too much powder produces a different incident and reflected angle, which results in an inaccurate plot. The correct angle is required to determine the correct composition. A very finely ground sample works best because it fits the dish more exactly than a coarse one and it is easier to strike off and level to the correct, uniform angle. The powder is leveled using a glass slide because glass is not porous and will not leave irregularities in the sample surface.

Figure 27 shows the specimen holder locked in place in the XRD machine. The machine allows rotation of the specimen if desired to eliminate randomness caused by imperfections in sample preparation. In this case, there was no need to use the rotational mechanism.

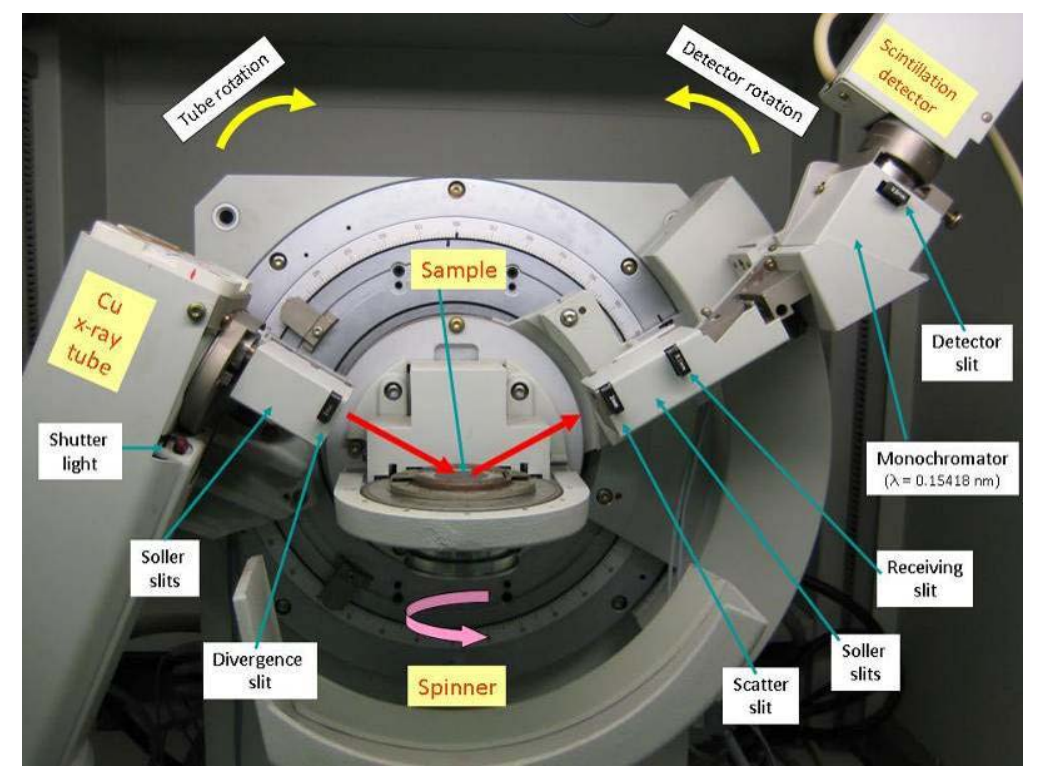

Figure 27. Photograph of experimental setup illustrated in Figure 21.

When the test begins, an x-ray source and detector rotate around the sample. The source beam reflects from the sample and is read by the detector. The angle between these two devices-twice the Bragg angle-is critical to making valid measurements. This angle is found by adding the angle to the horizontal surface of the source $(\omega)$ and the detector $(\gamma)$. The Bragg angle $(\Theta)$ is used in Bragg's Law to determine the spacing between the atoms, 
which is how the materials are identified. Twice the Bragg angle is plotted against intensity using a computer program that continuously receives data from the machine. Intensity is a measurement of how many photons are detected. The range of $2 \Theta$ used was 16- 70 degrees. This result was obtained by running a very rapid test through a larger range, then narrowing down where useful data should be obtained based on this quick run and prior experience with similar materials. The speed that the source and detector moved was 0.25 degrees per minute. Again, this value was based on an initial quick run and experience showing that a slower rotation is beneficial for cementitious materials.

The plots obtained for each sample were then imported into J ade, a software application for analyzing the raw data provided from the test. First, the background is set. The graph has several intensity peaks representing both chemicals and background noise. It is important to filter out the background to obtain meaningful results. Technical judgment must be exercised to determine the difference between random noise and the smaller peaks graphed from the data. For this reason, a conservative approach was taken, leaving in anything that could possibly represent a chemical component. Next, an unrestricted search was run to try to match all peaks in the sample against the extensive J ade database. Each database component is assigned a figure of merit (FOM) based on how well its major peaks match up with the sample. In general, the three largest peaks of an element must match the powder's peaks in order to provide some certainty that the element is actually present in the pozzolan. Some materials may look good promising in some parts of the data but are negated by unmatched peaks. This sensitivity and uncertainty in measurement and data analysis reinforces the importance of meticulous sample preparation. For some elements, the exact location of the peaks is extremely important, and small variances may either produce false positive or false negative matches. The best (lowest) FOMs are then presented to the user.

For cases where peaks are unmatched in the general search, a guided chemical search can be made. Based on chemical analyses of known pozzolans from similar regions, it is known that many oxides are present in these pozzolans. Using this information to guide a more specific search, J ade was used to search on oxides previously found in pozzolan and attempt to match other peaks in the plots. The results of this search were combined with the general search to provide more complete information on the composition of each pozzolan sample. 
This combination of tests is generally sufficient to characterize those components that contribute significantly to pozzolan properties. The smaller peaks may represent either trace elements or more common elements with a low presence in the particular sample. Making such distinctions relies on the investigator's technical experience and interpretive logic. Some matching of peaks becomes more of an approximation than a positive identification, but these approximations can still be informative when based on technical expertise and experience.

After all of the component elements are determined, J ade computes the magnitude of quantity of each in the sample. This is accomplished by computing the area under the peaks utilizing Lorenzan and Gaussian regressions. Sometimes J ade cannot find a mathematically suitable fit based on the peaks determined in the chemical analysis. In such cases, some peaks may need to be manually removed. Also, J ade may mistakenly assign a peak to a less-important chemical where more than one chemical has a peak that closely matches the sample peak. The results also need to be reviewed for this kind of error and revised accordingly. Only when the regression falls within a specified tolerance will the program output the composition of the pozzolan by volume and weight of its component chemicals.

\subsubsection{Compression testing}

Compressive testing was designed to follow ASTM C109/ C109M, Standard Test Method for Compressive Strength of Hydraulic Cement Mortars as closely as possible under the available laboratory conditions.

In this test, pozzolan samples must again be ground to a fine powder, but only to an upper size boundary of 45 microns. The same grinding device used for the XRD samples was used again. The runtime was set for several hours to ensure a sufficient sample quantity at the desired particle size. A 45 micron filter was not available, so a larger sieve was used to screen out all particles that were obviously too coarse. This approach produced a powder sample that was judged to be sufficient for the experiments.

For the test batches of concrete, each pozzolan sample presented six different mixture possibilities. Because three pozzolans were used for this portion of the study, 18 distinct mixtures were needed. Sufficient quantities of Pozzolan S were available for two mortar cubes of each mixture, but there was only enough of Types $\mathrm{G}$ and $\mathrm{A}$ for one cube per mixture. Com- 
pressive testing to failure was set for 28 days; compressive strength at 7 days and greater than 28 days were not investigated because the 28-day strength is most relevant to typical engineering applications.

Each concrete test mixture contained a different combination of sand, lime, pozzolan, cement, and water, although some mixes contained no lime. The sand and lime were the types commonly used in masonry work, and the selected cement was Type I Portland. An initial exploratory test series was performed using material proportions shown in Table 4.

Table 4. Mix proportions of compressive specimens used in initial testing.

\begin{tabular}{|l|l|l|l|l|l|}
\hline $\begin{array}{l}\text { Set } \\
\text { Number }\end{array}$ & $\begin{array}{l}\text { Sand/cementitious } \\
\text { ratio }\end{array}$ & $\begin{array}{l}\text { Lime } \\
(\%)\end{array}$ & $\begin{array}{l}\text { Pozzolan } \\
(\%)\end{array}$ & $\begin{array}{l}\text { Portland } \\
\text { Cement (\%) }\end{array}$ & $\begin{array}{l}\text { Water/cementitious } \\
\text { ratio }\end{array}$ \\
\hline 1 & $3.25 / 1.25$ & 15 & 85 & 0 & 0.5 \\
\hline 2 & $3.25 / 1.25$ & 40 & 60 & 0 & 0.5 \\
\hline 3 & $3.25 / 1.25$ & 0 & 50 & 50 & 0.5 \\
\hline 4 & $3.25 / 1.25$ & 15 & 42.5 & 42.5 & 0.5 \\
\hline 5 & $3.25 / 1.25$ & 30 & 35 & 35 & 0.5 \\
\hline
\end{tabular}

Note that the percentages given for each cementitious material (lime, pozzolan, and cement) represent that component in relation to the total volume of cement, not the total concrete volume. It is evident that the first two sets shown in Table 4 might be expected to be extremely weak because they contain no Portland cement. The percentage of cement in the other batches does not exceed 50\%. This initial exploratory mixture produced weak cubes that crumbled easily. Based on that finding, the mixtures were changed to those shown in Table 5 for the tests documented in this report.

Table 5. Mix proportions of compressive specimens.

\begin{tabular}{|l|l|l|l|l|l|l|}
\hline $\begin{array}{l}\text { Set } \\
\text { Number }\end{array}$ & Series & $\begin{array}{l}\text { Sand/cementitious } \\
\text { ratio }\end{array}$ & $\begin{array}{l}\text { Lime } \\
(\%)\end{array}$ & $\begin{array}{l}\text { Pozzolan } \\
(\%)\end{array}$ & $\begin{array}{l}\text { Cement } \\
(\%)\end{array}$ & $\begin{array}{l}\text { Water/cementitious } \\
\text { ratio }\end{array}$ \\
\hline 1 & A, G, H & $3.25 / 1.25$ & 0 & 15 & 85 & 0.5 \\
\hline 2 & A, G, H & $3.25 / 1.25$ & 0 & 25 & 75 & 0.5 \\
\hline 3 & A, G, H & $3.25 / 1.25$ & 0 & 35 & 65 & 0.5 \\
\hline 4 & A, G, H & $3.25 / 1.25$ & 0 & 50 & 50 & 0.5 \\
\hline 5 & A, G, H & $3.25 / 1.25$ & 15 & 42.5 & 42.5 & 0.5 \\
\hline 6 & A, G, H & $3.25 / 1.25$ & 30 & 35 & 35 & 0.5 \\
\hline
\end{tabular}


It can be seen that there are two major trends in the test sets. The first four remove the lime, which is generally weaker, and investigate the result of replacing more and more concrete with pozzolan. The last three sets keep the proportions of pozzolan and cement equal while adding more lime. Upon inspection, these cubes were judged to be of higher quality than the initial specimens.

The methodology of mixing is important in obtaining the correct results. First, each material must be measured. The dry materials are then placed in a large container and mixed thoroughly by hand, without water, to ensure a uniform composition. Water is then added and mixed for several minutes, wetting all surfaces and creating a concrete paste. These steps are represented in Figures 28 - 30.

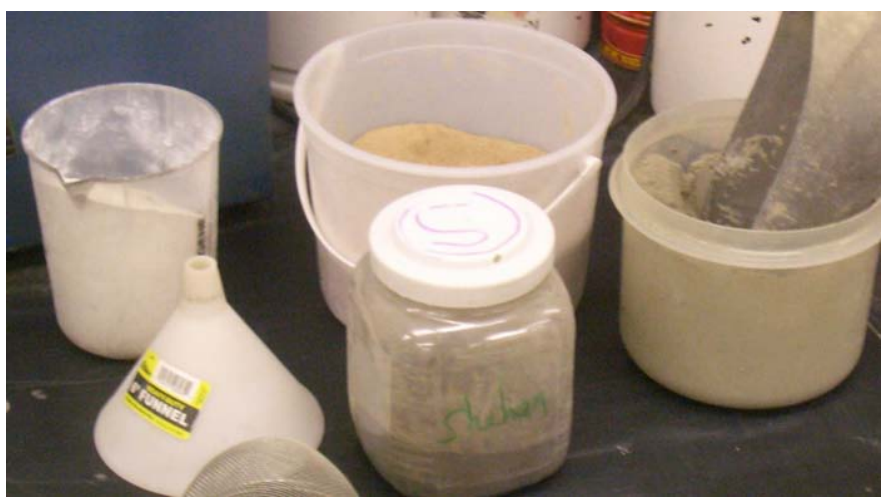

Figure 28. Materials used for concrete mix.

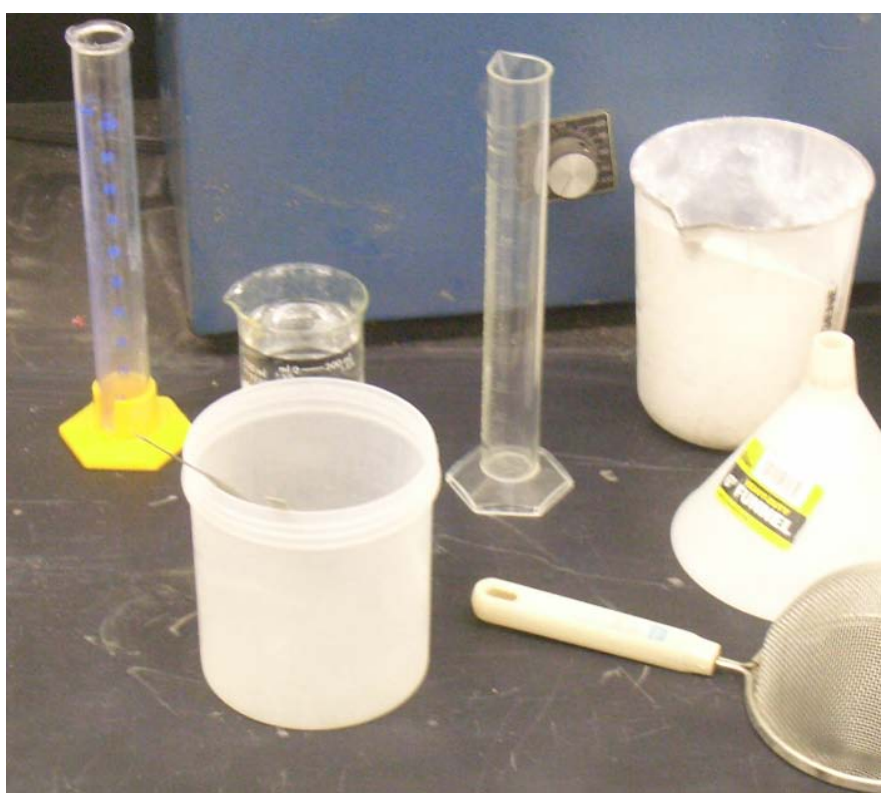

Figure 29. Measuring equipment for concrete mix. 


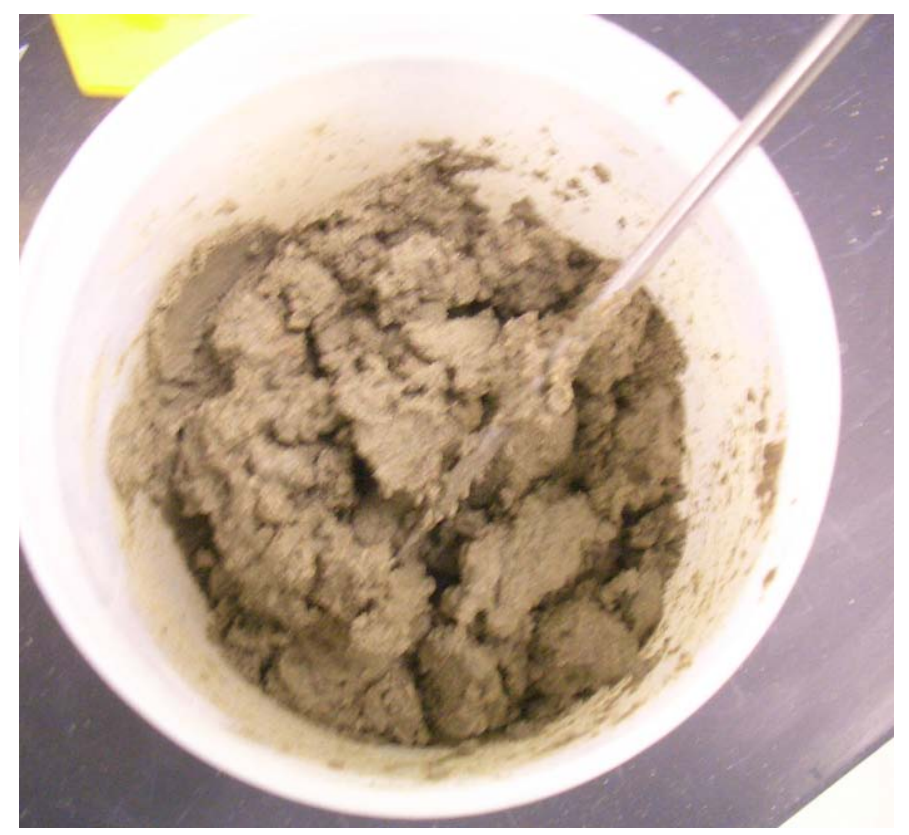

Figure 30 . Wet concrete mix.

The paste is then cast into molds like those seen in Figure 31. These molds have rigid sides and open tops, and they produce 2 inch cubes as required by ASTM C109/C109M. Each cube was partially filled and tamped 25 times to ensure that any voids are filled by compaction. This task is known as a lift. Three lifts were used to fill each cube, which was then struck off at the top with a flat edge. The cubes must be left to cure for 24 hours before being removed from the molds. Figure 32 shows the wet concrete in the molds.

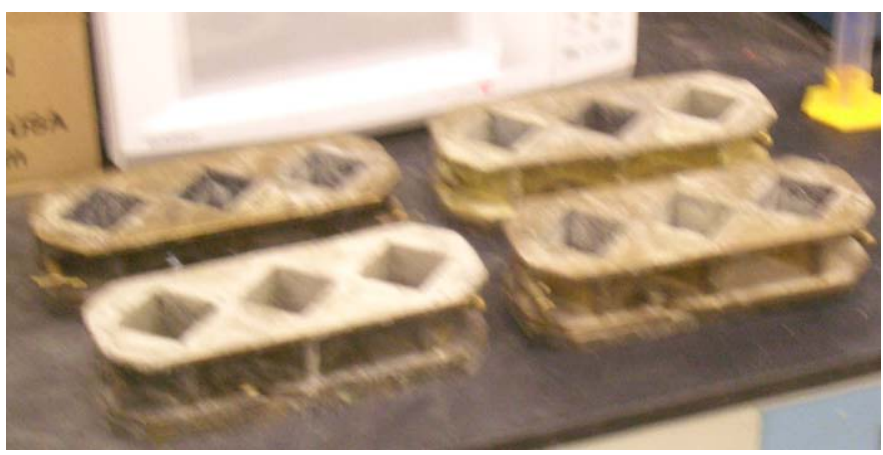

Figure 31. Empty molds for casting cubes. 


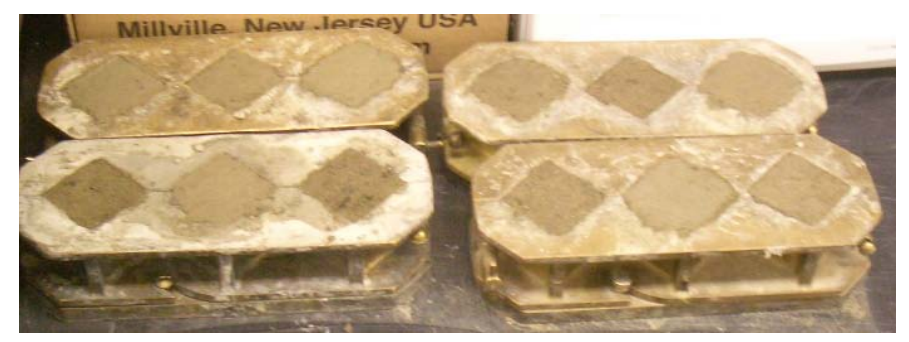

Figure 32. Concrete setting in cube molds.

After 24 hours, the cubes were extracted from the molds and began to be moist-cured for 28 days. The ASTM procedure suggests placing the cubes into a lime-water bath, but this option was not available in the lab facilities provided. As an alternative, the cubes were immersed in water and covered with wet paper towels at least once a day to ensure that the towels remained wet and the cubes would not become dry (Figure 33).

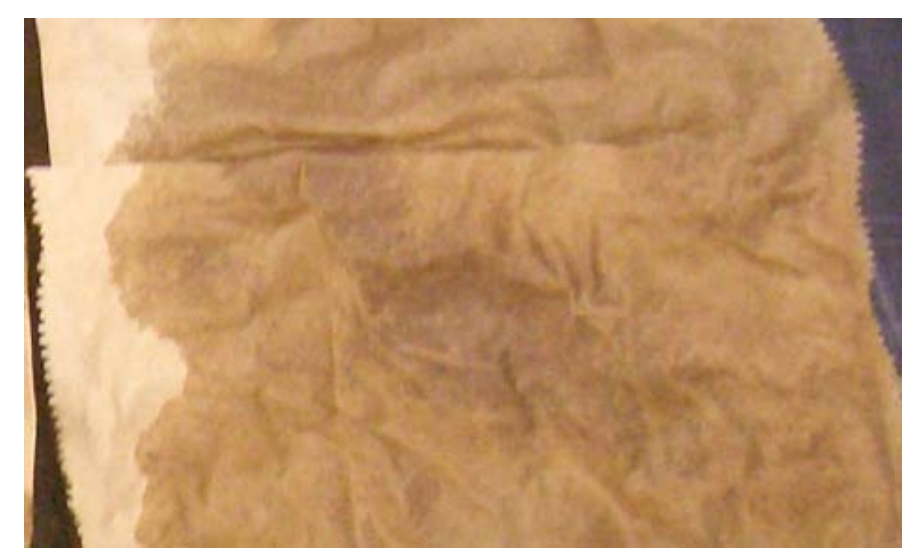

Figure 33. Cast cubes kept moist under paper towels.

After 28 days, the cubes had cured sufficiently to be tested in compression according to ASTM C109/C109M. Figures 34 and 35 show the loading machine used for this purpose and the computer used to control the machine and record data. The loading machine is capable of generating 50 kilopounds (kips) of force. For a cube surface nominally measuring 4 square inches, the machine could apply up to 12.5 kips per square inch (ksi), much more than would be needed to test the cubes to failure. 


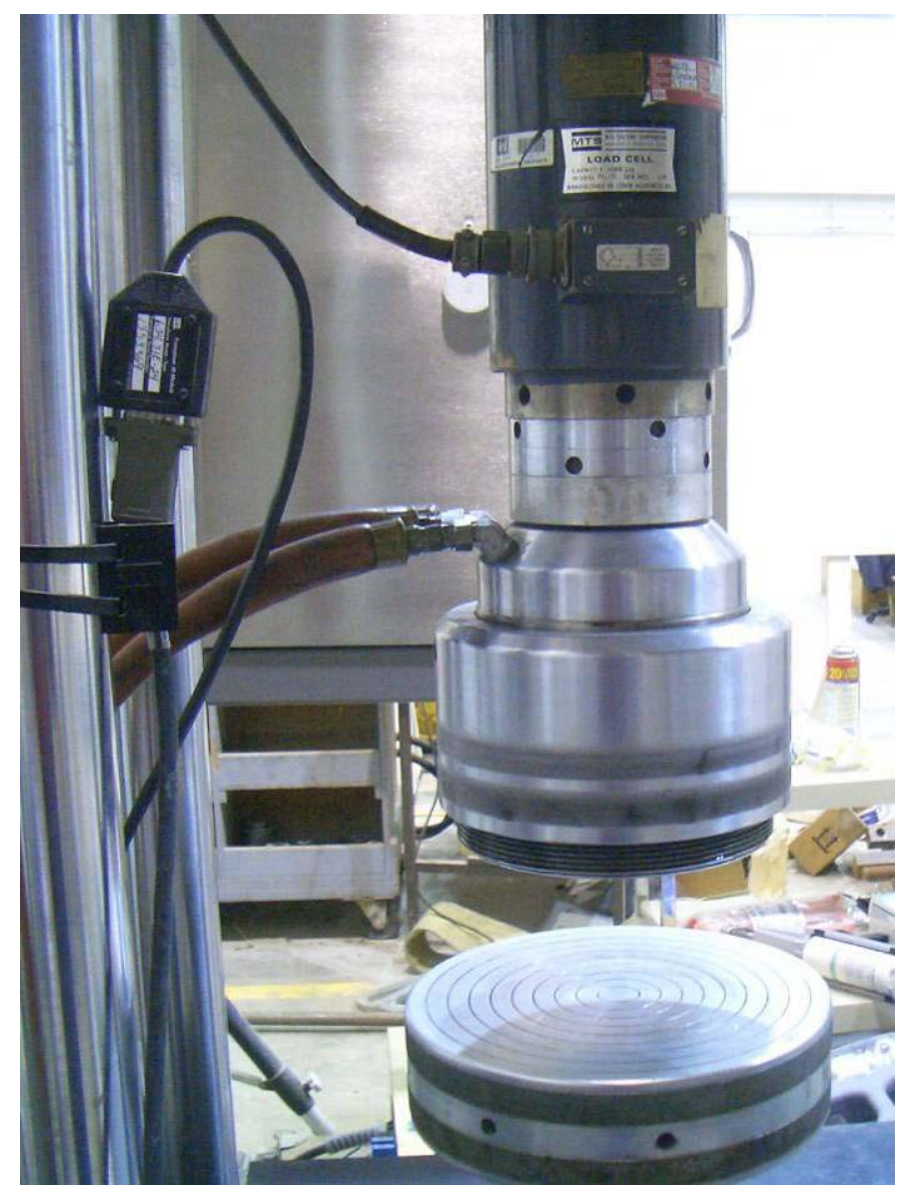

Figure 34.50 kip loading machine.

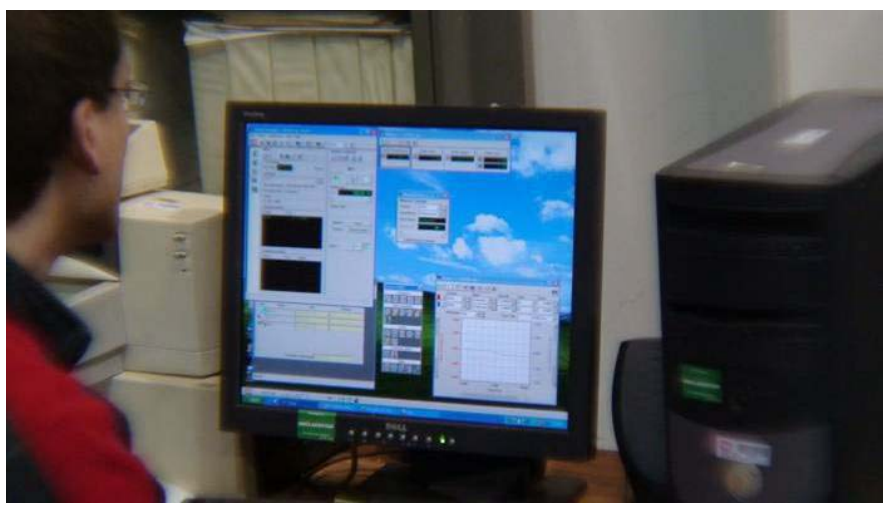

Figure 35. Computer control of 50 kip machine.

The specimen must be prepared for crushing. A cube face that touched a side of the mold during casting tends to have the truest area, so these are the faces that are marked for application of the load, as shown in Figure 36. Calipers are used to confirm the measurements, as shown in Figure 37. Three measurements should be taken for each dimension to ensure accuracy. An extensometer is then attached tightly to the flattest face of the cu- 
be in the axial direction using two rubber bands. This setup can be seen in Figure 38. The fit must be very snug, both to ensure strain compatibility between the specimen and extensometer and to prevent the extensometer from falling off. The assembly is then centered between the loading plates, as shown in Figure 39. Figure 40 shows a sample cube being crushed in compression.

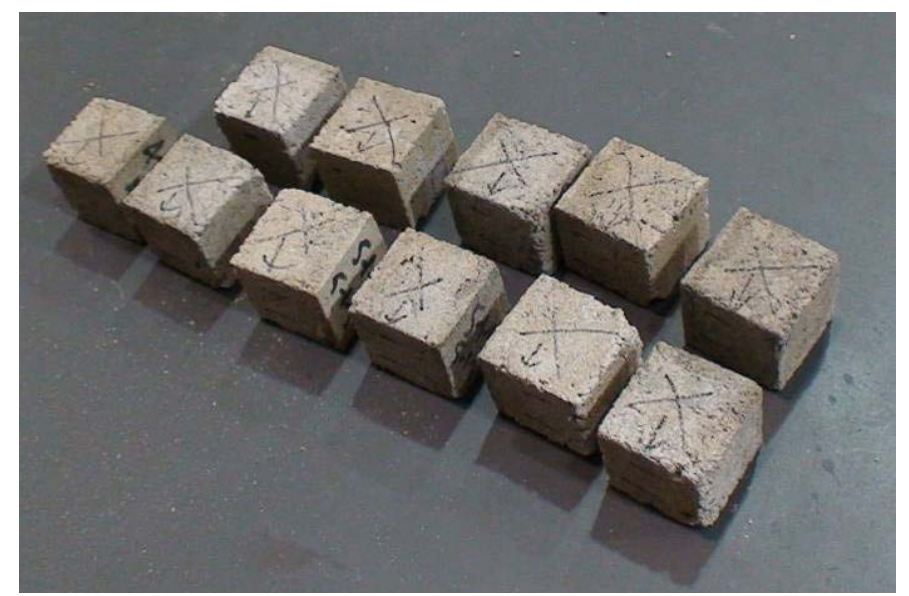

Figure 36. Cubes with faces to be compressed marked.

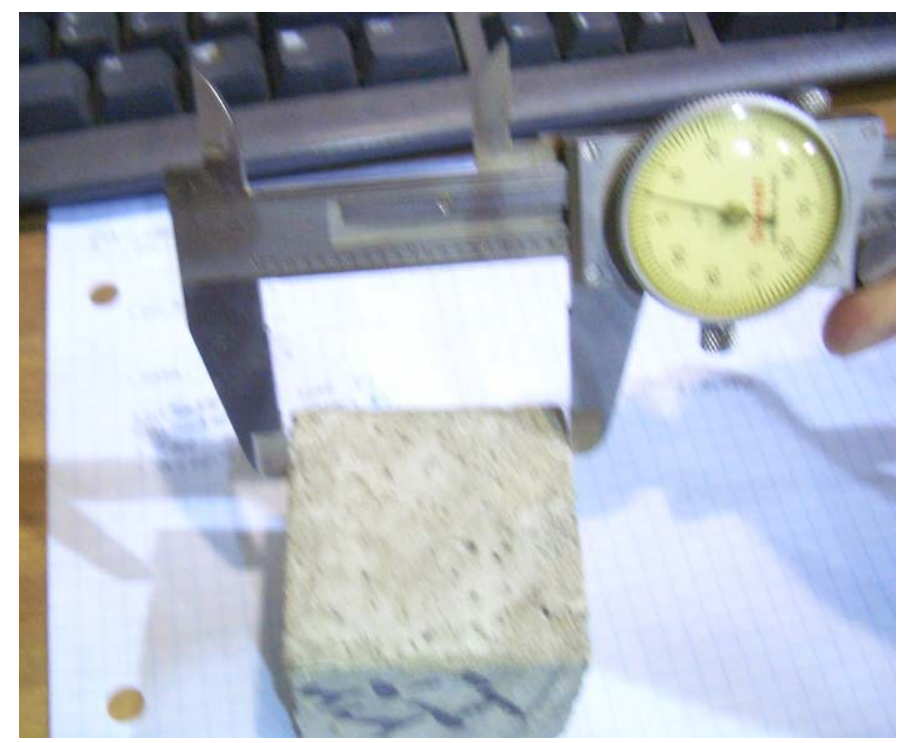

Figure 37. Determination of cube dimensions. 


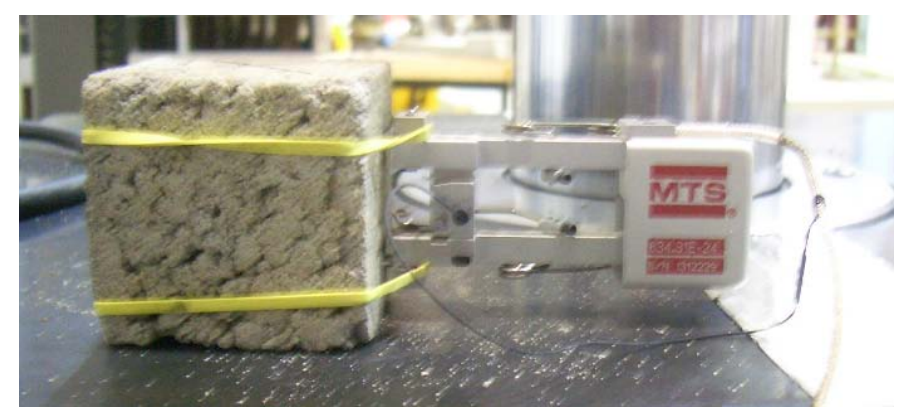

Figure 38. Extensometer attached to specimen.

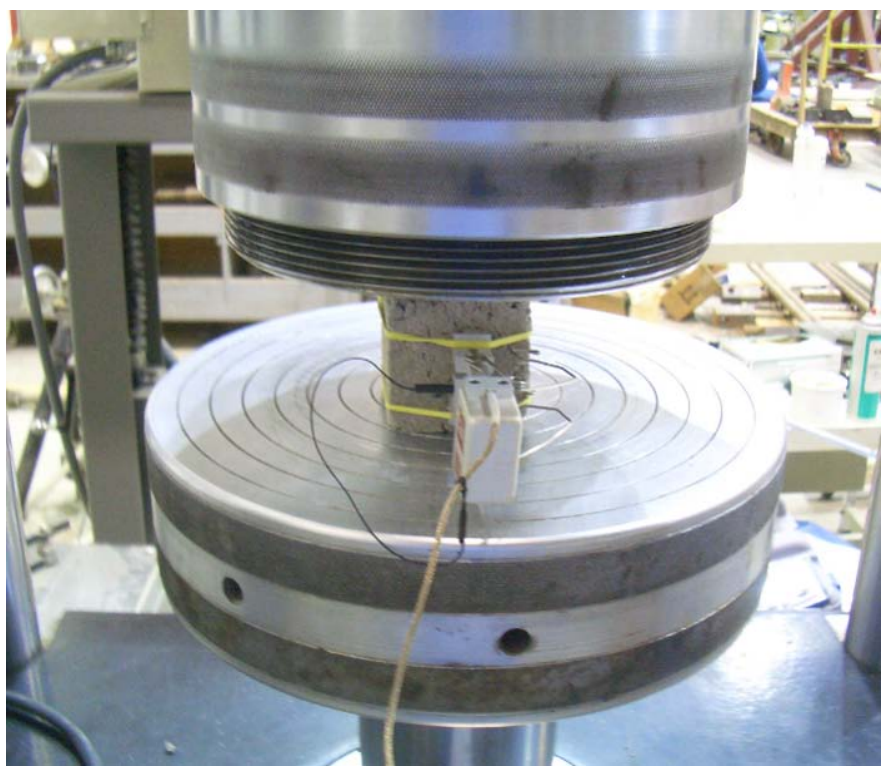

Figure 39. Specimen ready for compression test.

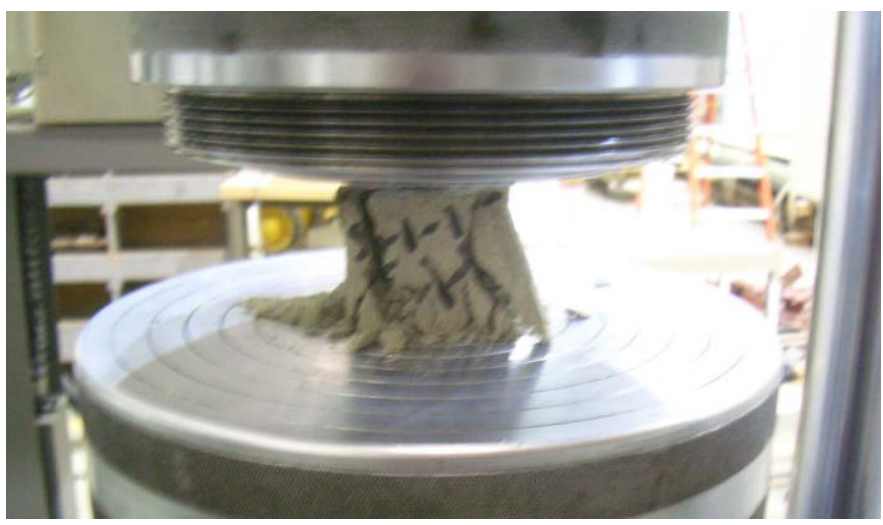

Figure 40. Sample cube being crushed.

ASTM C109/ C109M allows the loading application rate to be set at the user's discretion for up to half the ultimate expected load, if the ultimate load is expected to exceed $3 \mathrm{kips}$, which is expected to be true in this scenario. The load must then be adjusted until breaking so that the entire process takes between 20 and 80 seconds. Therefore, a testing program had to be 
written to control the rate and duration of the loading. The final result prescribed one rate of load application instead of two. This solution was used for two reasons. First, using an initial faster rate, a weaker-than-expected specimen may break even faster than the minimum of 20 seconds required for the test. The slower rate ensures that testing will comply with the ASTM protocol even if a 3 kip ultimate load is not achieved. Second, the variation in exact cube sizes makes calculating deformation more challenging. If all cubes were exactly 2 inches in height with a known modulus of elasticity, then strain and deformation could be computed for all levels of loading. However, because of deviations in cube height and uncertainty about Young's modulus of the test mixtures, each cube was slightly different. In order to avoid rewriting the loading code for each test, a general program that would cover all test cubes was considered more suitable and efficient. The slower rate used in this test allowed all cubes to resist failure for 20 - 80 seconds for compliance with the protocol even considering differences in ultimate strength attributable to the given size and possible inconsistencies.

After these tests were run for all cubes, the data were analyzed using J ade to obtain stress/strain and stress/ time plots.

\subsection{Results}

\subsubsection{Pozzolan S}

\subsubsection{XRD results}

Figures 42 - 44 show the J ade output files for Pozzolan S. There are three types of output. Figure 42 plots the sample intensity against $2 \Theta$. Superimposed on this are the plots for each element assumed to be a part of the pozzolan in order to compare. Figure 43 has the sample intensity on top and the location of each of its element peak intensities below. Finally, the pie chart in Figure 44 graphically represents the composition of a sample. The composition of this pozzolan differed from the other samples and the expectation greatly. Despite the various degrees of difficulty in characterizing the other specimens, they all generally conformed to the expectation of being dominated by oxides-particularly silicon and aluminum, as well as iron and calcium to a lesser extent. However, as can be seen in Table 6, the amount of oxides in Pozzolan S is minor compared with the primary component (aluminum titanium carbide). 


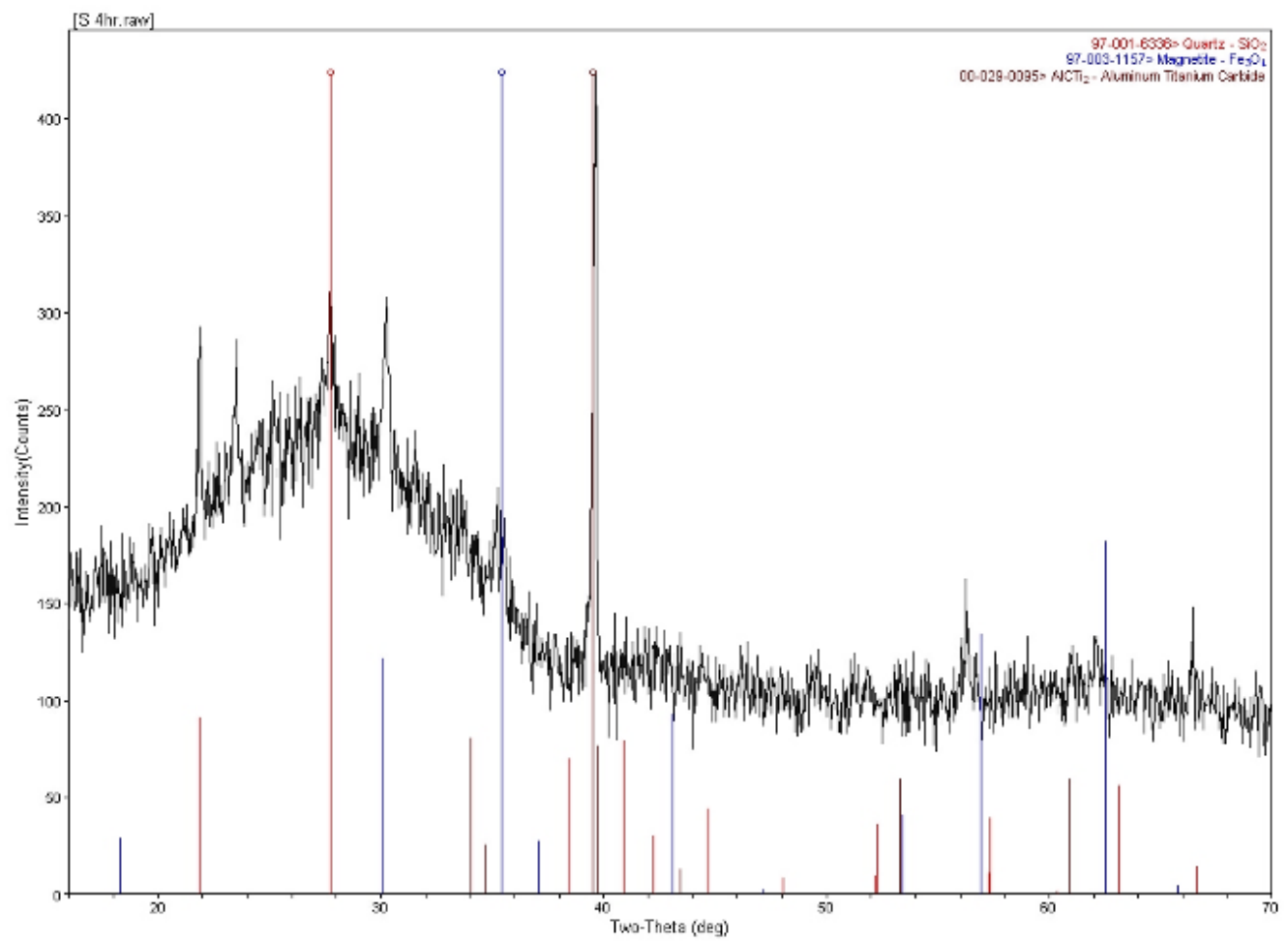

Figure 41. Jade element intensity results superimposed over XRD results for Pozzolan S.

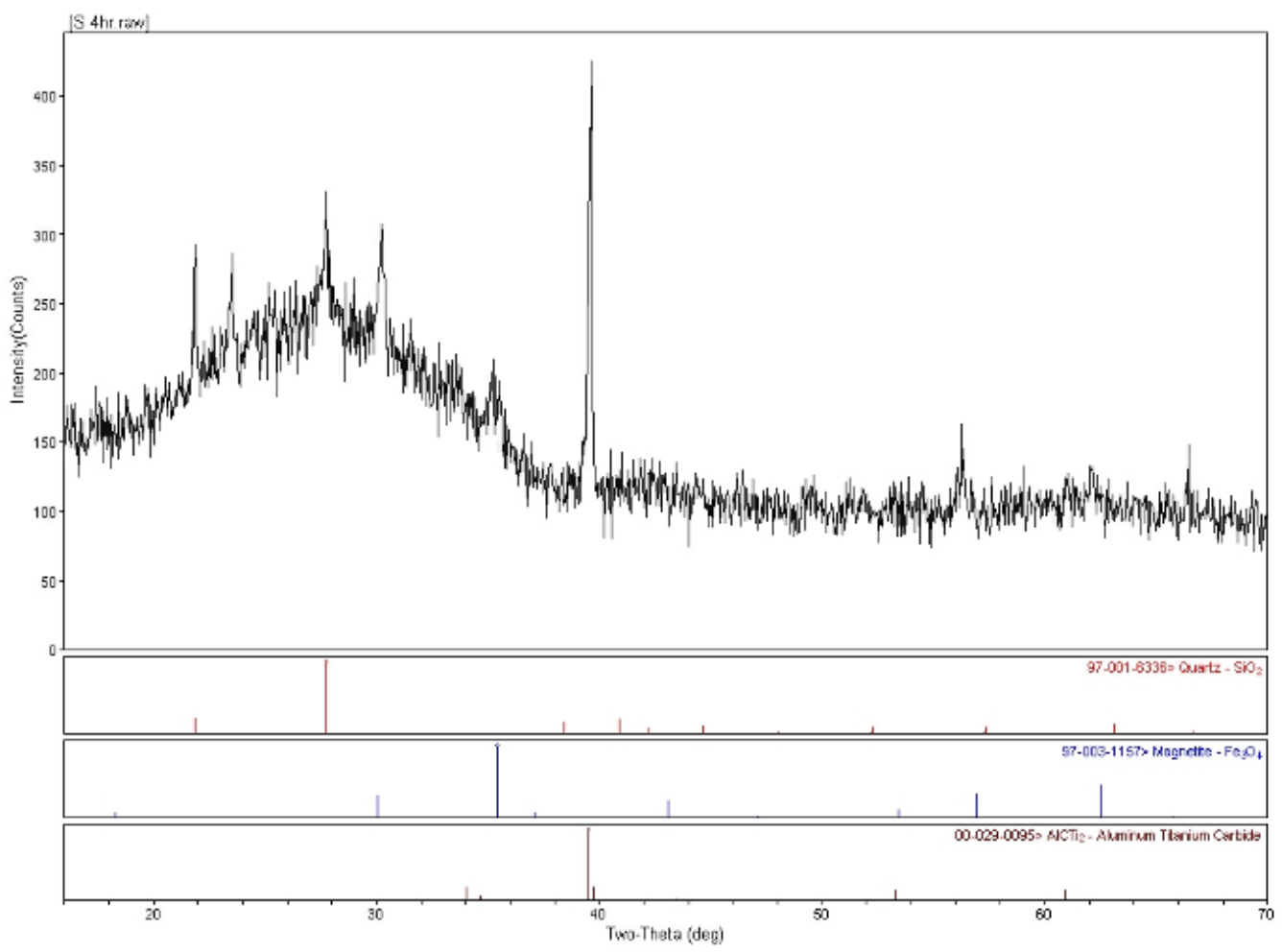

Figure 42. Location of major peak intensities of the elements in Pozzolan S. 
Quart $-\mathrm{SiO}_{2} \approx \mathrm{Wh} \%=4.4(2.0)=$

Magnetite $-\mathrm{Fe}_{3} \mathrm{O}_{4} \leqslant \mathrm{Wt} \%=7.7(3.4)>$

$\mathrm{AlCTi}_{2} \approx W \mathrm{~W} \%=87.9(38.9)>$

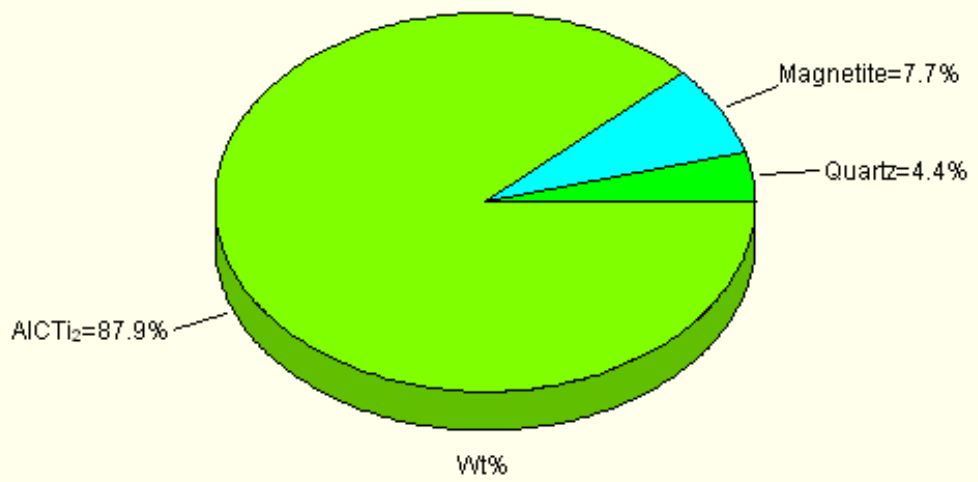

Figure 43. Graphical representation of components of Pozzolan S.

Table 6. Composition of Pozzolan S.

\begin{tabular}{|l|l|l|l|}
\hline Element & Chemical Formula & Percent by Weight & Percent by Volume \\
\hline Aluminum titanium carbide & $\mathrm{AlCTi}_{2}$ & 87.9 & 87.8 \\
\hline Magnetite, synthetic from melt & $\mathrm{Fe}_{3} \mathrm{O}_{4}$ & 7.7 & 6.1 \\
\hline Quartz low & $\mathrm{SiO}_{2}$ & 4.4 & 6.1 \\
\hline
\end{tabular}

Based on this testing, this sample of Pozzolan S appears to be carbonbased rather than oxygen-based. It is possible that this pozzolan does in fact contain a significant amount of carbon, but this result greatly deviates from both previous testing and the other Pozzolan S samples from this analysis. The iron and silicon oxides are expected, but they contribute little more than $10 \%$ to the sample.

\subsubsection{Compression results}

Twelve cubes containing Pozzolan S were tested in compression, two from each of the six mixture sets. As noted, this was possible because an extra amount of Pozzolan S was available to allow for casting a second set of specimens. The higher stress recorded for each cube in the pair was taken as the compressive strength of the specimen. From this set of data for each set, Young's Modulus could also be approximately determined.

The first set met Type M mortar strength (ASTM C-270) by reaching 2,545 psi. The expectations for modulus and ultimate strain were based on compressive strength $-2,250 \mathrm{ksi}$ and 0.0011 , respectively. The modulus is expected to be 900 times the compressive strength for concrete-based mor- 
tar, and the expected ultimate strain can then be computed from the modulus and compressive strength. This specimen had a larger ultimate strain of 0.00161 , almost $45 \%$ greater than expected. This led to a lower than expected modulus of 1,581 ksi, 31\% lower than predicted. Table 11 shows the data.

Several conclusions can be drawn from this set. First, the replacement of $15 \%$ of cement with pozzolan increased ductility while keeping the strength high. This result can be seen in the higher ultimate strain and the less-brittle failure path plotted in Figure 45. This had the effect of reducing Young's Modulus, as it became more of a secant than a tangent modulus. The true modulus is only for the linear elastic range, which this specimen left due to ductile behavior. However, this extra ductility likely reduced strength, as the cube just barely met the threshold. This is to be expected, as ductility and strength normally are traded off for each other.

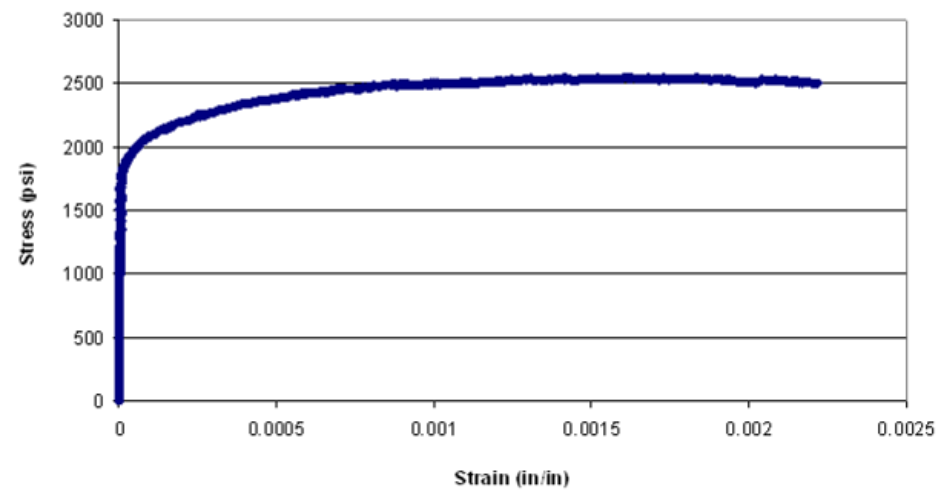

Figure 44. Stress/strain diagram of Set 1 for Pozzolan S.

Five more sets were run in the same manner, and their data can be seen in Figures $46-50$. Looking at the entire set of results allows several general conclusions to be drawn. As with the first set, most specimens were more ductile and less stiff than expected. The sole exception is the last set, which failed at such a low level of stress that it is almost worthless. Furthermore, the replacement of cement with pozzolan only works to a certain point. The first four sets all contained no lime with decreasing amounts of cement. As expected, strength also went down. However, the drop was very high, with none of the sets reaching 2,500 psi and only the second one coming close. This result indicates that only a small amount of this type of pozzolan can be used to replace cement. This is confirmed further through the last two sets. Adding a weaker lime to the mix further decreased strength, making removal of cement a dysfunctional option. Thus, it ap- 
pears that an ideal mix of these cementitious materials should include no lime and a maximum of 10 to $15 \%$ Pozzolan S. Further testing with sets containing 5- 15\% pozzolan might be more instructive in determining the most efficient replacement ratio.

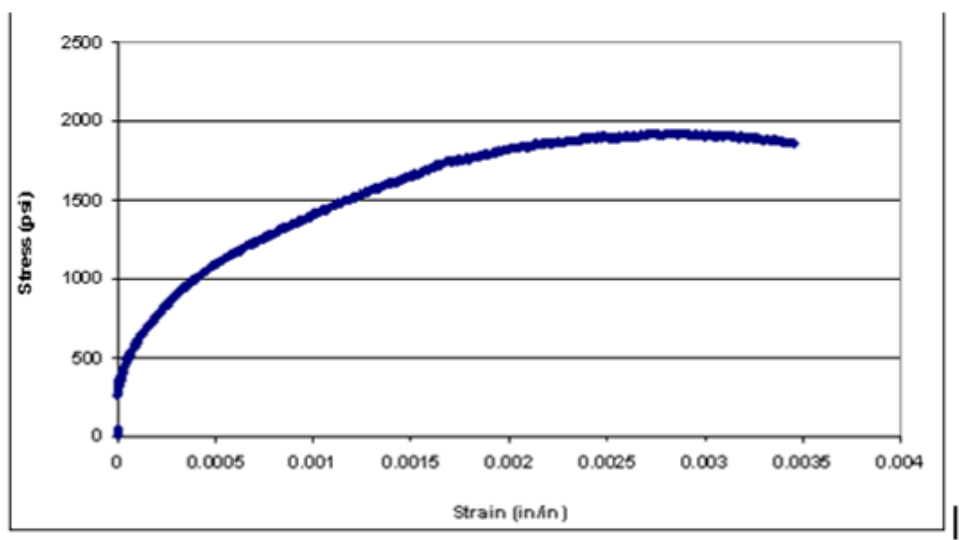

Figure 45. Stress/strain diagram of Set 2 for Pozzolan S.

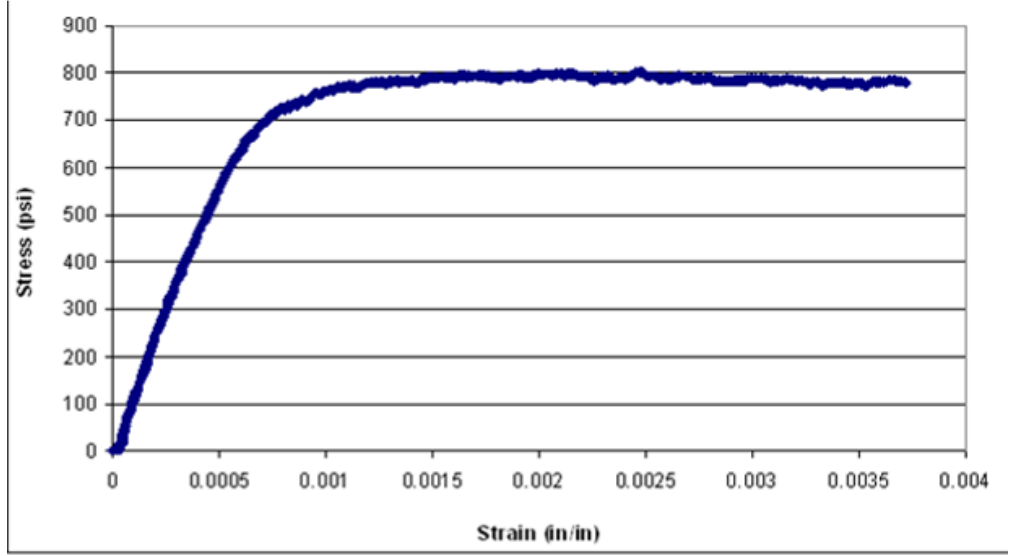

Figure 46. Stress/strain diagram of Set 3 for Pozzolan S.

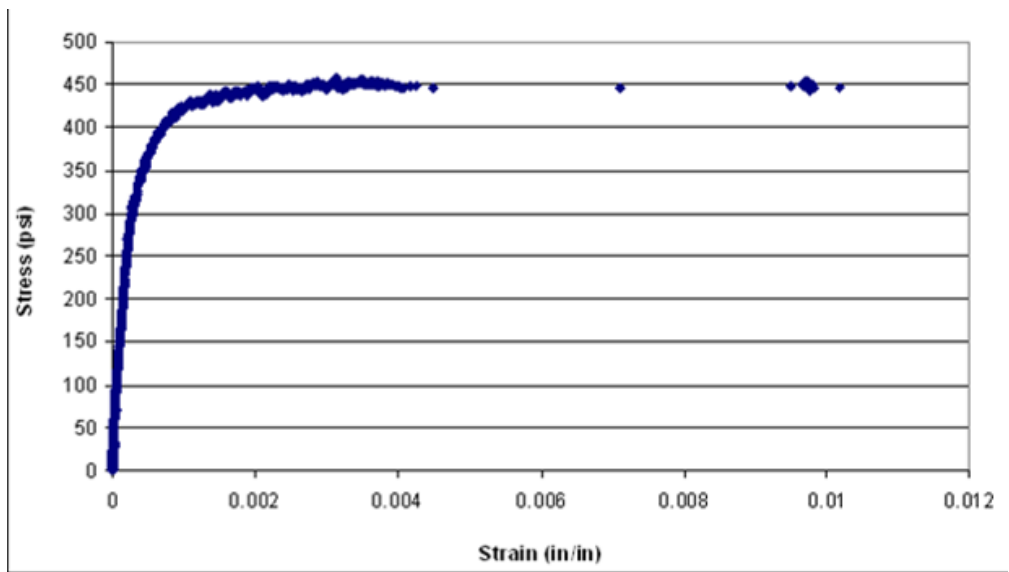

Figure 47. Stress/strain diagram of Set 4 for Pozzolan S. 


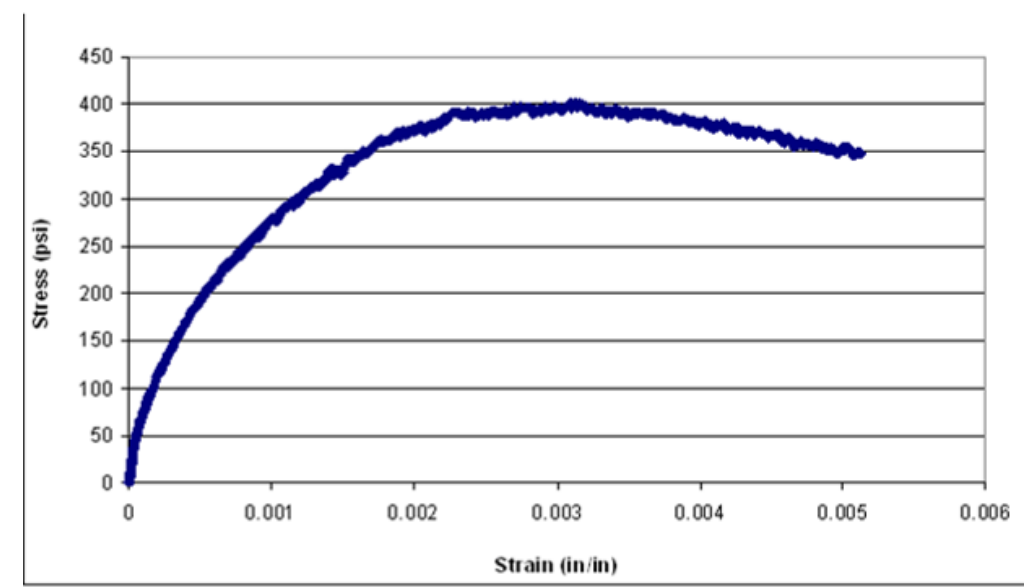

Figure 48. Stress/strain diagram of Set 5 for Pozzolan S.

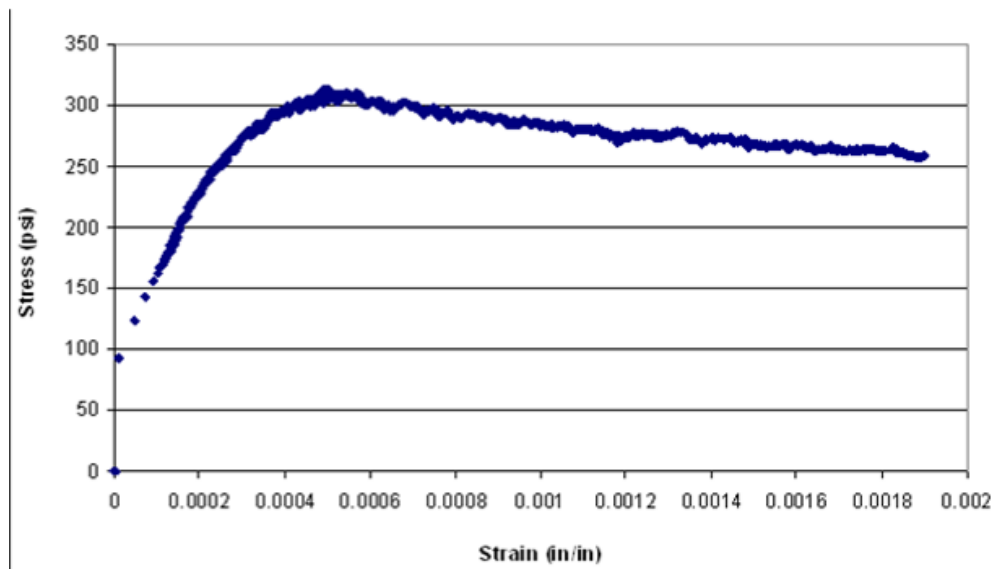

Figure 49. Stress/strain diagram of Set 6 for Pozzolan S.

\subsubsection{Pozzolan G}

\subsubsection{XRD results}

Pozzolan G did not sufficiently match any compounds in J ade's unrestricted search, so a chemical search had to be performed on the expected composition. This returned varying results. The major elements were easily identified, but determining the complete composition required much manual examination of smaller peaks to determine differentiation. The results are shown in Figures 51 - 53 and Table 7.

The results for Pozzolan $\mathrm{G}$ are less precise for other types. This uncertainty is attributable to the large number of trace elements detected, which resulted from many small peaks in the data. However, the expected oxides did plainly appear in the results. The presence of silicon oxide and aluminum oxide as the largest and second-largest material portions, respectively 
corresponded perfectly with the expectation. Titanium was also found in this sample, but it is a typical trace element found in several other pozzolans as well.

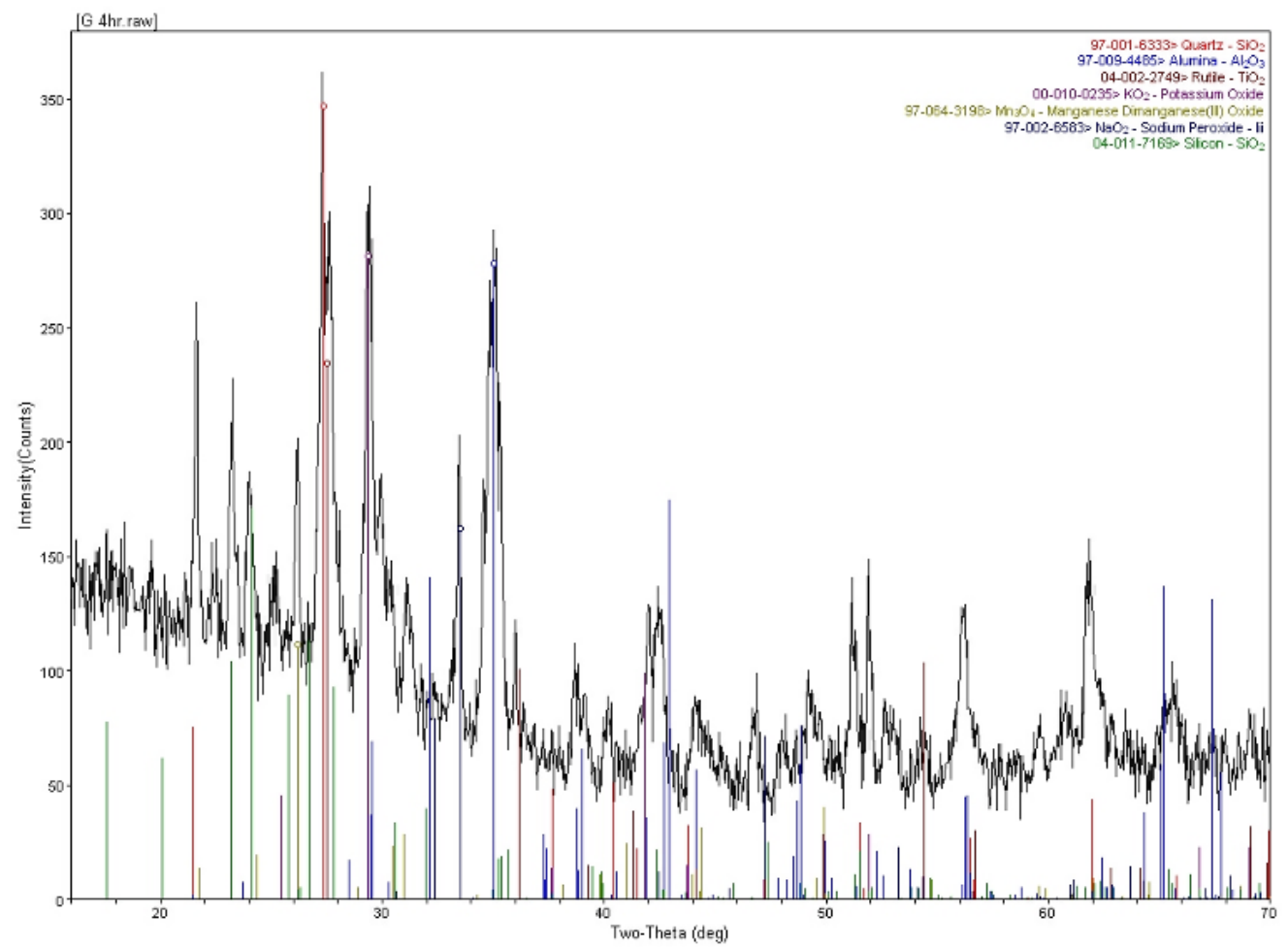

Figure 50. Jade element intensity results superimposed over XRD results for Pozzolan G. 


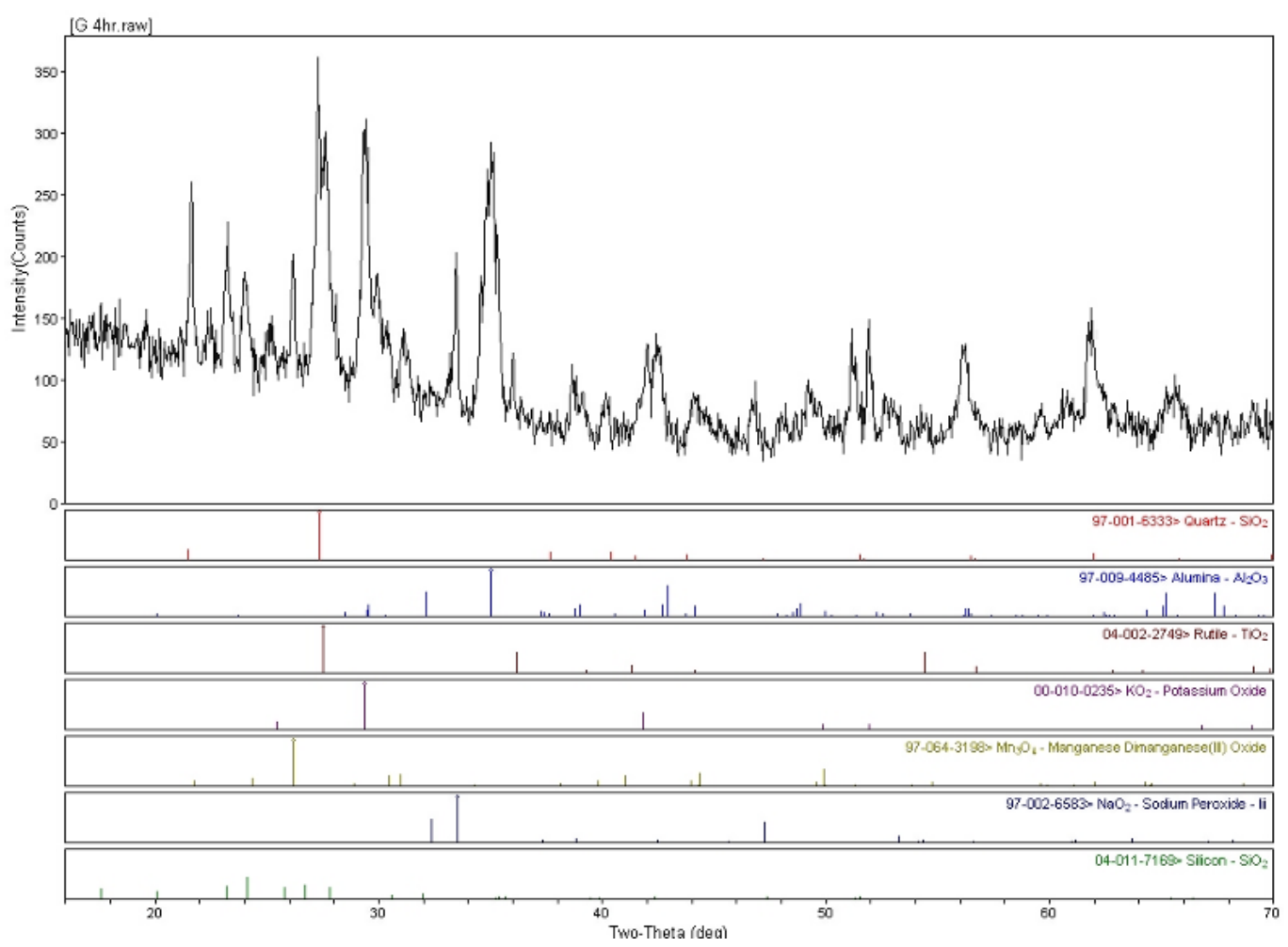

Figure 51. Location of major peak intensities of the elements in Pozzolan G.

Quart - $\mathrm{SiO}_{2} \leqslant \mathrm{Wt} \%=3.2(2.0)>$

Alumina - $\mathrm{Al}_{2} \mathrm{O}_{3}<\mathrm{W}$ it $\%=34.3(21.8)>$

Rutile $-\mathrm{TiO}_{2} \approx \mathrm{ht} \%=1.1(0.7)>$

$\mathrm{KO}_{2} \leq \mathrm{Wt} \%=1.2(0.8)=$

$\mathrm{Mn}_{3} \mathrm{O}_{4}<\mathrm{Wt} \%=0.7(0.4)=$

$\mathrm{NaO}_{2} \approx \mathrm{W}^{2} \%=1.6(1.0)=$

Silicon $-\mathrm{SiO}_{2}<\mathrm{Wt} \%=57.9(36.7)=$

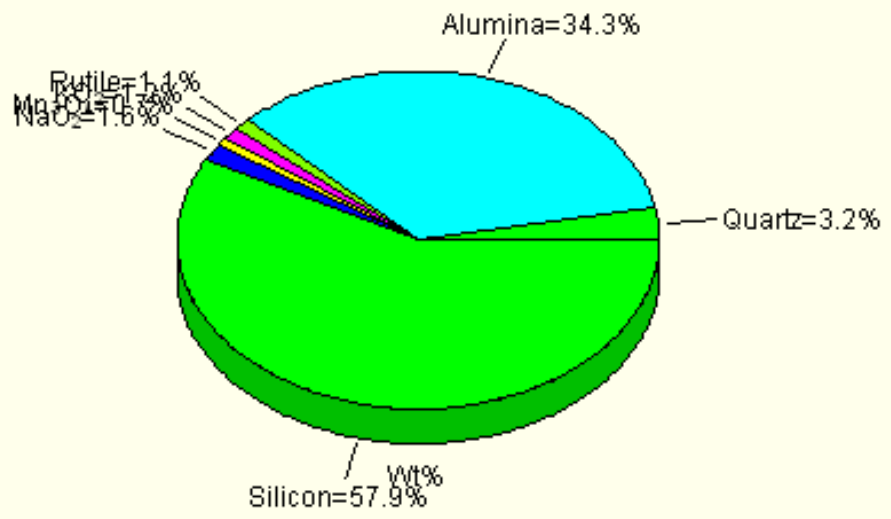

Figure 52. Graphical representation of components of Pozzolan G.

Table 7. Composition of Pozzolan G.

\begin{tabular}{|l|l|l|l|}
\hline Element & Chemical Formula & Percent by Weight & Percent by Volume \\
\hline Silicon oxide & $\mathrm{SiO}_{2}$ & 57.9 & 70.1 \\
\hline Alumina kappa, syn & $\mathrm{Al}_{2} \mathrm{O}_{3}$ & 34.3 & 22.1 \\
\hline
\end{tabular}




\begin{tabular}{|l|l|l|l|}
\hline Quartz low & $\mathrm{SiO}_{2}$ & 3.2 & 2.7 \\
\hline Sodium peroxide & $\mathrm{NaO}_{2}$ & 1.6 & 1.8 \\
\hline Potassium oxide & $\mathrm{KO}_{2}$ & 1.2 & 2.0 \\
\hline Rutile, syn & $\mathrm{TiO}_{2}$ & 1.1 & 0.6 \\
\hline Manganese dimanganese(III) oxide & $\mathrm{Mn}_{3} \mathrm{O}_{4}$ & 0.7 & 0.7 \\
\hline
\end{tabular}

\subsubsection{Compression results}

Six cubes containing Pozzolan G were tested in compression, one from each mixture set. Data were obtained and analyzed in the same manner as for the Pozzolan S specimens. However, the pattern of results was different from that established for Pozzolan S. The stress/ strain diagrams for this pozzolan can be seen in Figures 54 - 57, with the exception of sets 1 and 4, which returned poor results due to machine error.

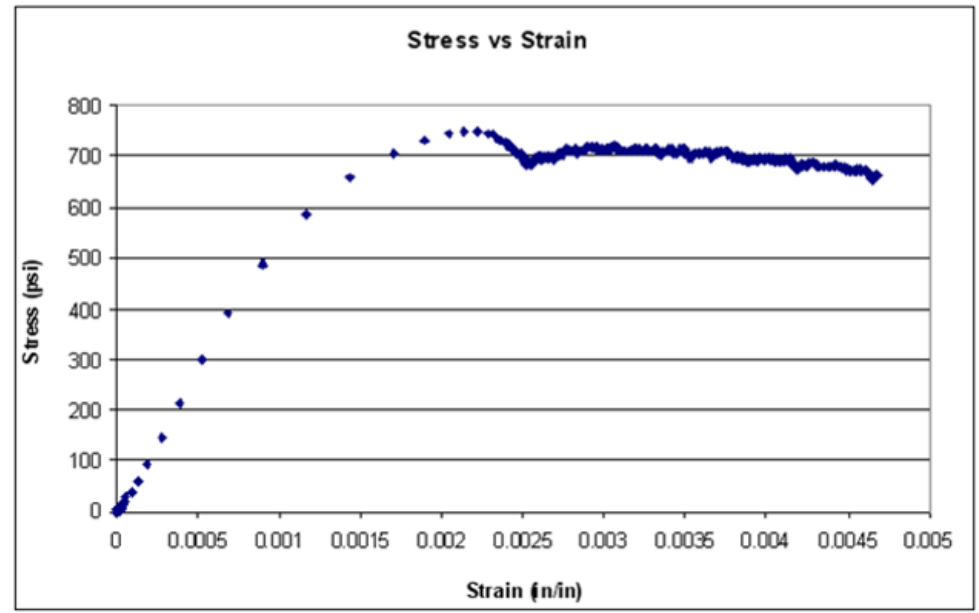

Figure 53. Stress/strain diagram of Set 2 for Pozzolan G. 


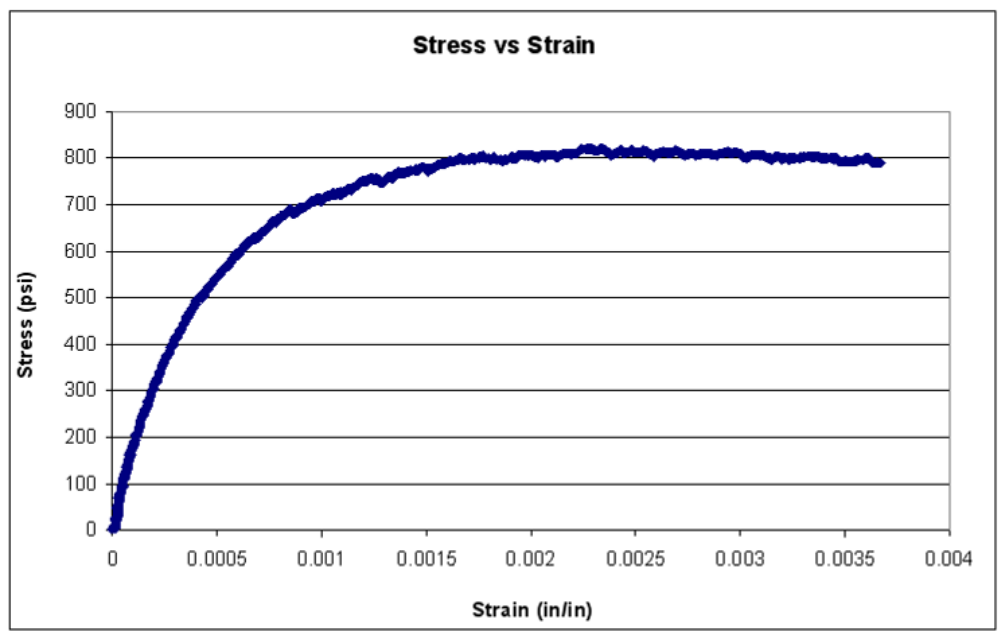

Figure 54. Stress/strain diagram of Set 3 for Pozzolan G.

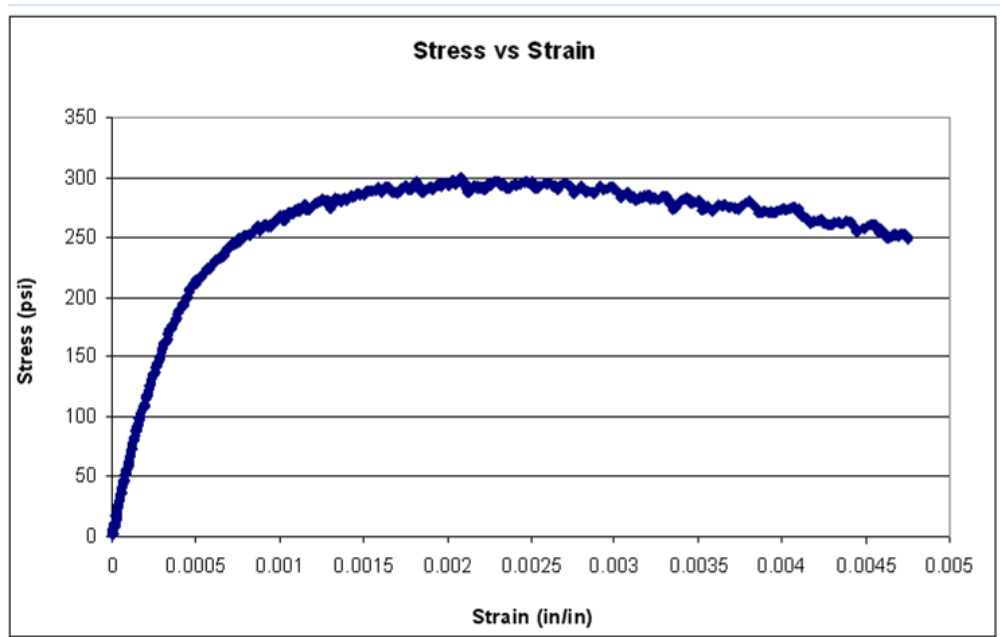

Figure 55. Stress/strain diagram of Set 5 for Pozzolan G.

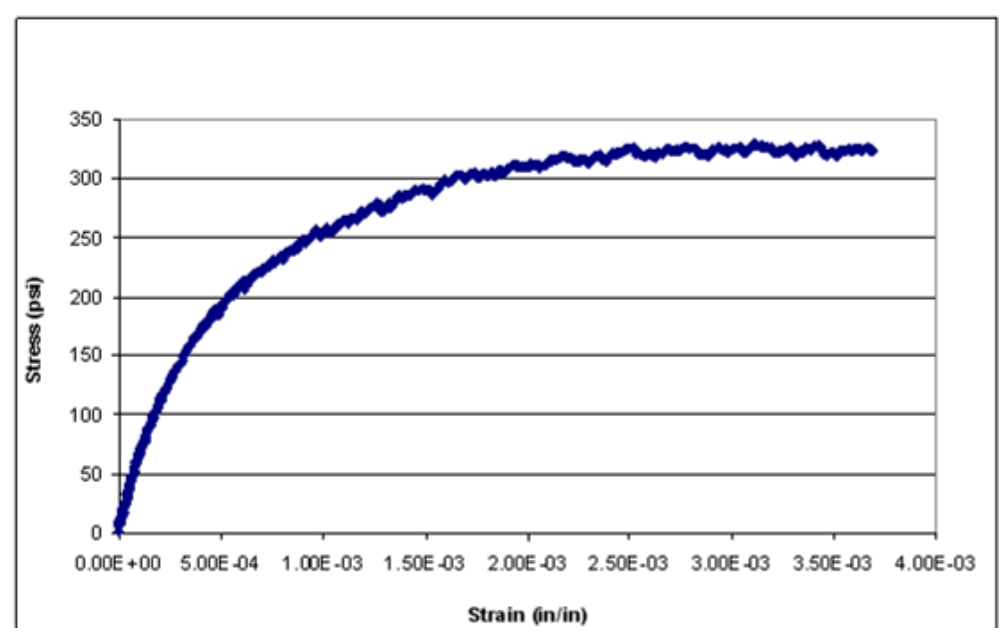

Figure 56. Stress/strain diagram of Set 6 for Pozzolan G. 
The first Pozzolan G set, supposedly the strongest of all tested, broke at just 888 psi-only about one-third the strength of Type M mortar (plot not shown). In terms of strength, this mixture could be classified as a Type $\mathrm{N}$ mortar, which is less common but still useful where weaker mortars meet the design requirement for strength. From this initial result, one might expect the strength of subsequent sets to fall off appreciably. However, this was not the case. The first three sets were all fairly close in ultimate strength, strain, and modulus values, suggesting that initial replacement of cement with pozzolan weakens the specimen but that the percentage of pozzolan may be relatively unimportant to the result. The unexpected stress/ strain diagram of the fourth specimen, not shown, suggested machine error but did not contradict this interpretation.

The last two test sets followed a pattern similar test to the first three. They are close in compressive strength but are significantly weaker than the first three due to the introduction of lime, and it appears that the amount of lime added did not influence strength significantly. However, at strength levels of approximately 300 psi, these last two specimens lack practical application.

Despite the lower strength, this pozzolan should not be dismissed as a cement substitute. In applications where Type $\mathrm{N}$ mortar is called for, it may be a very useful cement replacement. From the third set, up to $35 \%$ of Portland cement could be replaced by pozzolan as long as lime is not added. This represents an enormous reduction in the need for cement and also possibly in cost.

\subsubsection{Pozzolan A}

\subsubsection{XRD results}

The J ade analysis of the XRD results for Pozzolan A returned some of the best initial matches of all pozzolans tested. The general analysis found a match to andesine, an oxide containing calcium, sodium, aluminum, and silicon that is found pozzolans from the Verzasca Valley of Switzerland. Andesine comprised most of the sample. The search also found other trace oxides in the sample, as shown in Figure 58, 59, and Table 8. 


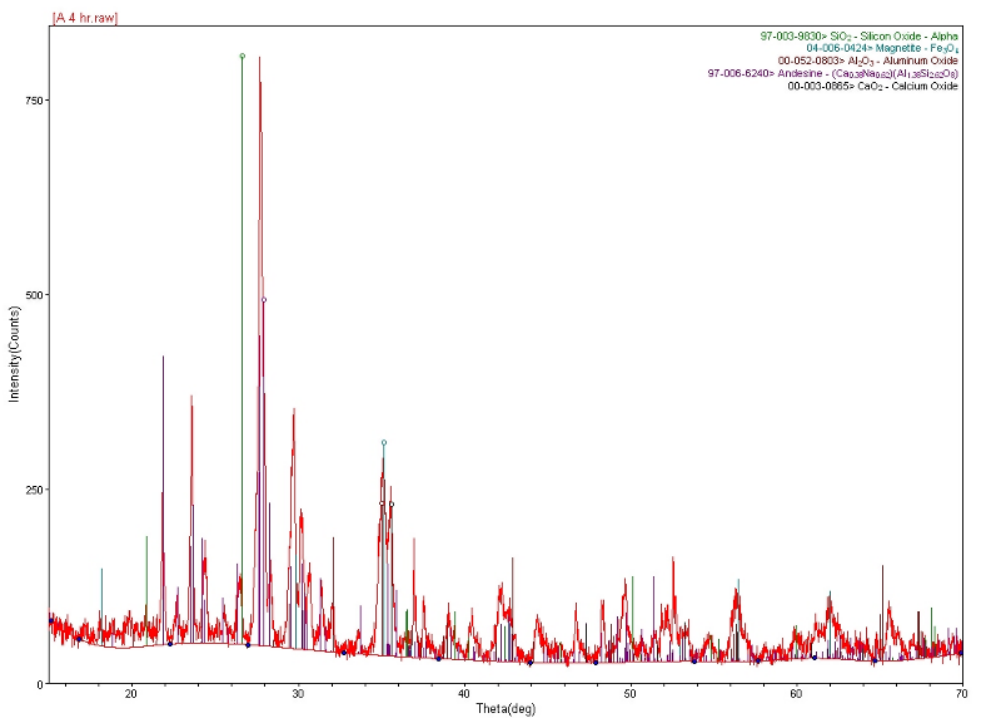

Figure 57. Jade element intensity results superimposed over XRD results for Pozzolan A.

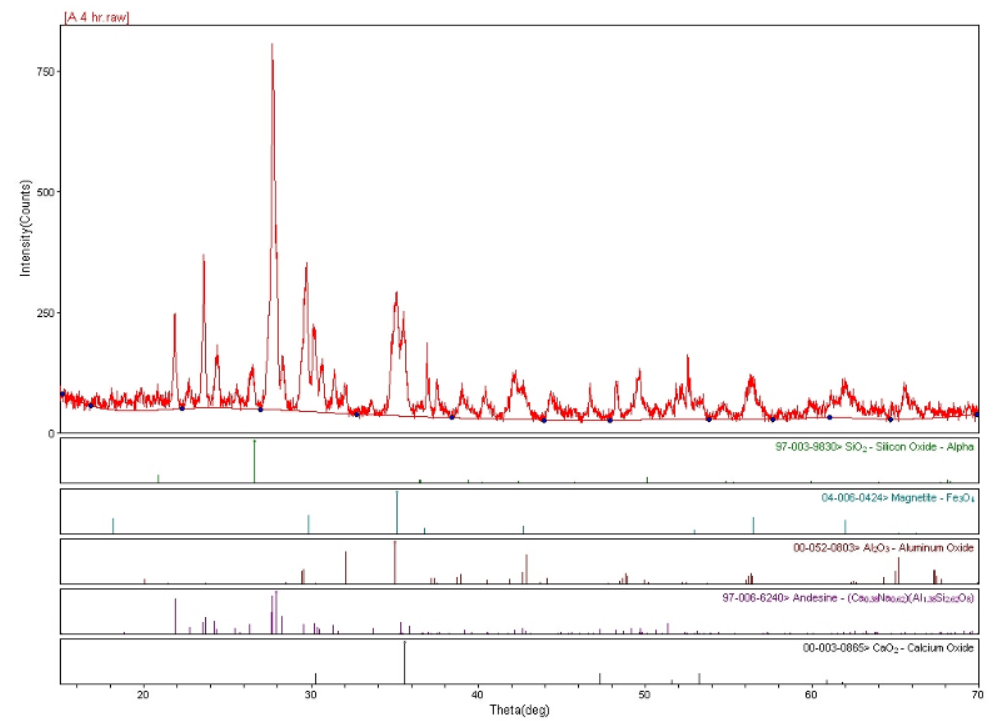

Figure 58. Location of major peak intensities of the elements in Pozzolan A.

Table 8. Composition of Pozzolan A.

\begin{tabular}{|l|l|l|l|}
\hline Element & Chemical Formula & Percent by Weight & Percent by Volume \\
\hline Andesine & $\left(\mathrm{Ca}_{0.38} \mathrm{Na}_{0.62}\right)\left(\mathrm{Al}_{1.38} \mathrm{Si}_{2.62} \mathrm{O}_{8}\right)$ & 96.6 & 97.6 \\
\hline Aluminum oxide & $\mathrm{Al}_{2} \mathrm{O}_{3}$ & 2.0 & 1.4 \\
\hline Magnetite, syn & $\mathrm{Fe}_{3} \mathrm{O}_{4}$ & 1.0 & 0.5 \\
\hline Silicon oxide-alpha & $\mathrm{SiO}_{2}$ & 0.4 & 0.4 \\
\hline Calcium oxide & $\mathrm{CaO}_{2}$ & 0.1 & 0.1 \\
\hline
\end{tabular}


Being dominated by andesine that is almost pure in nature, this sample includes a component that is known in other pozzolans, particularly the Swiss variety. Andesine contains only oxides, including a large amount of aluminum and silicon (which was expected based on the chemical analyses).

\subsubsection{Compression results}

Six cubes of Pozzolan A aggregate were tested in the same manner previously described. Patterns in the test results, which are shown in Figures 60

- 65, resembled those for Pozzolan G more closely than those for Pozzolan S.

The first specimen tested far below its Type M specification of 2,500 psi and, at 644 psi (Figure 60), it failed even to reach Type N mortar criteria. The next three specimens returned result patterns similar to the first set in terms of strength, strain, and modulus. Like Pozzolan G, Pozzolan A aggregate causes the admixture to lose strength when initially added, but extra added amounts appear to have little further impact. Also similarly to the Pozzolan G results, the introduction of lime further reduced the strength of the last two sets, but the percentage of lime did not make a significant difference.

Unlike Pozzolan G, this pozzolan does not appear to have any practical application due to its overall lack of strength as a Portland cement substitute. None of the six specimens met the criteria for Type N, the weakest of all typical construction mortars. Thus, use of this pozzolan in any admixture would not meet requirements. 


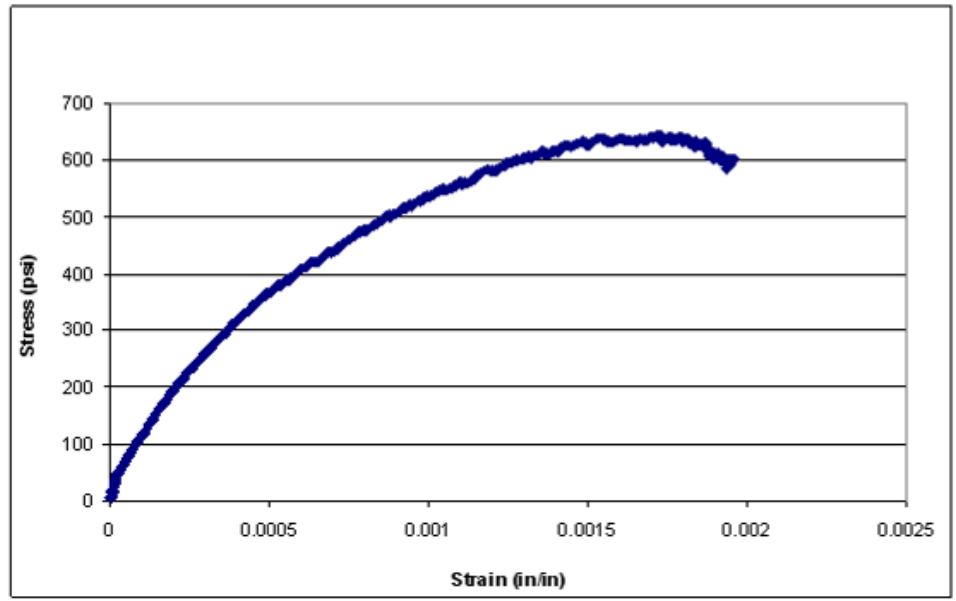

Figure 59. Stress/strain diagram of Set 1 for Pozzolan A.

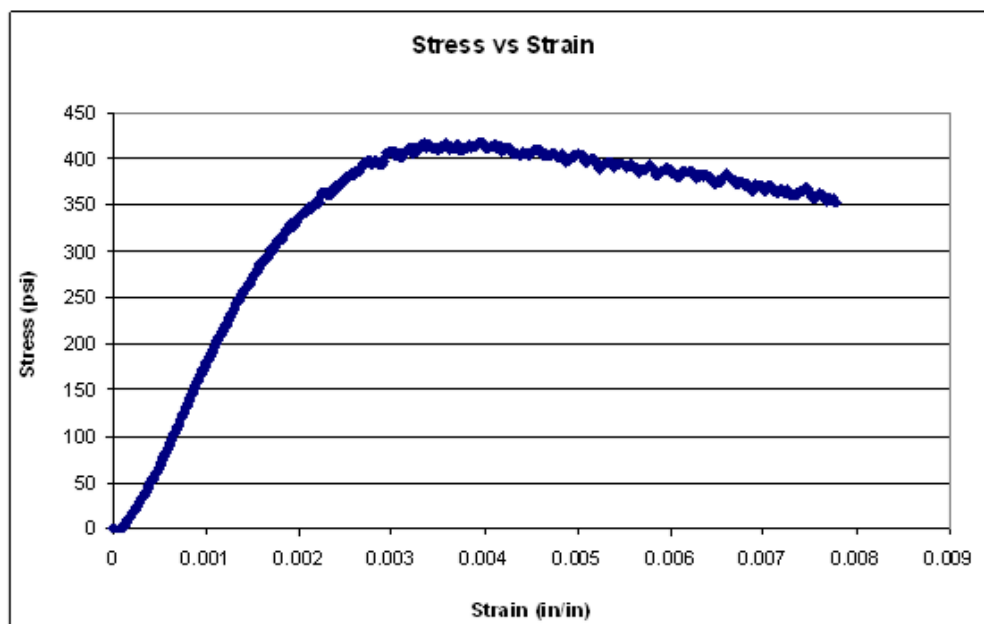

Figure 60. Stress/strain diagram of Set 2 for Pozzolan A.

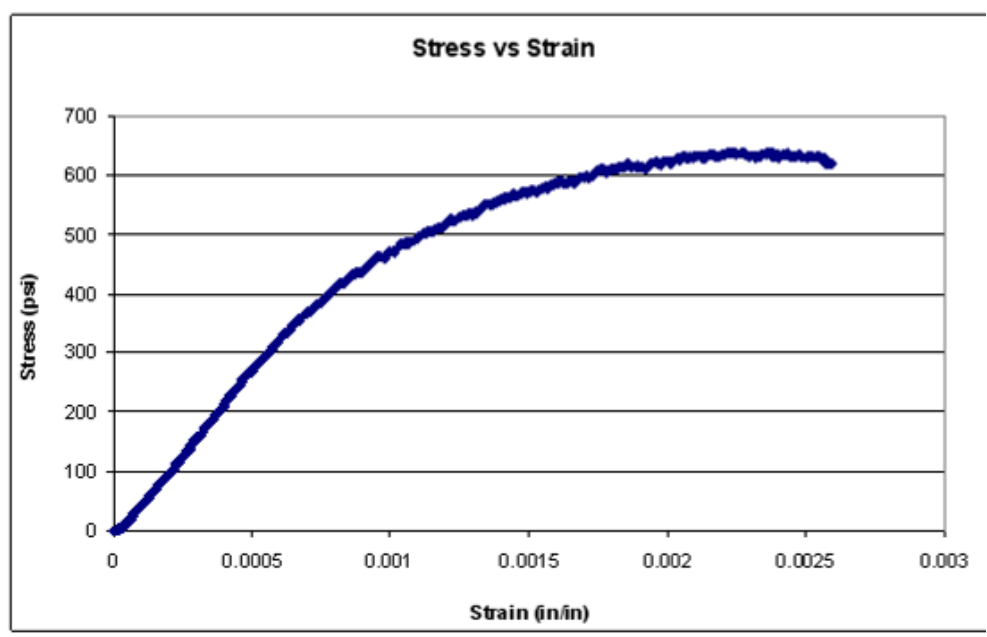

Figure 61. Stress/strain diagram of Set 3 for Pozzolan A. 


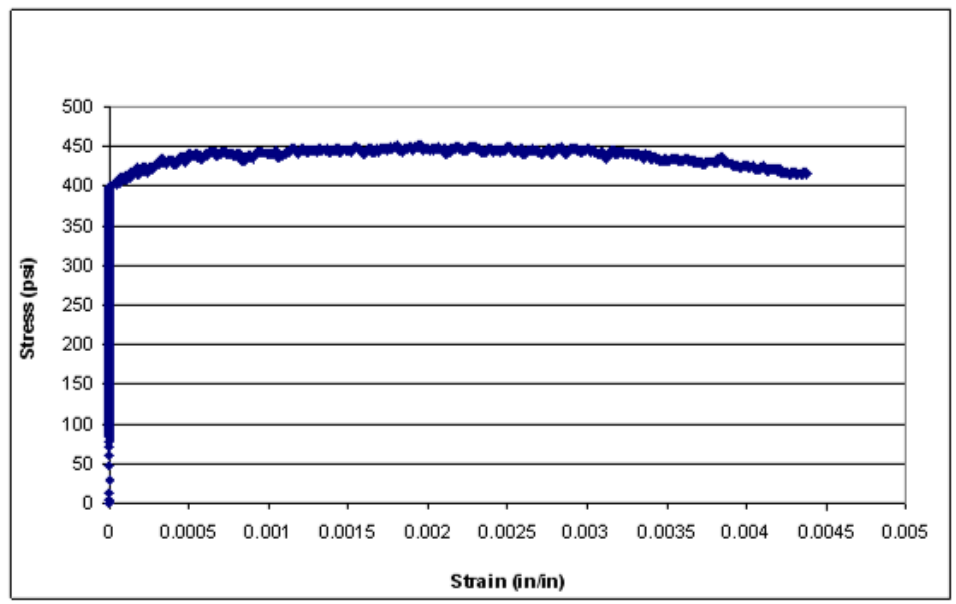

Figure 62. Stress/strain diagram of Set 4 for Pozzolan A.

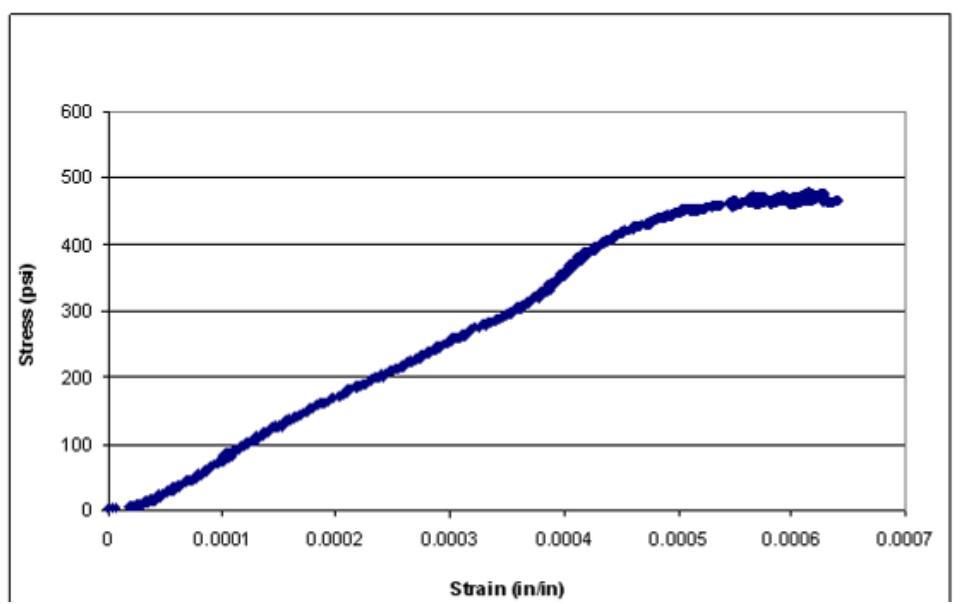

Figure 63. Stress/strain diagram of Set 5 for Pozzolan A.

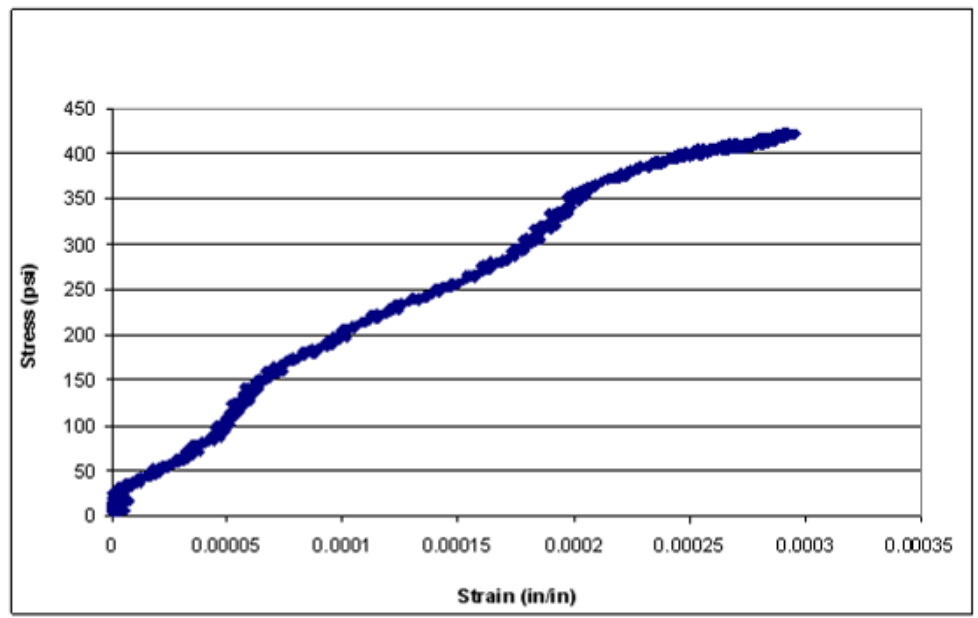

Figure 64. Stress/strain diagram of Set 6 for Pozzolan A. 


\subsubsection{Pozzolan R}

3.3.4.1 XRD results for coarse variety (Pozzolan R2)

J ade was able to return excellent composition matches for Pozzolan R2. The general search found a match to augite, an oxide that contains calcium, sodium, magnesium, aluminum, and iron. It is derived from a tephrite, which is volcanic rock. Augite comprised the majority of the sample. The chemical analysis also found other trace oxides in the sample, as shown in Figures 66 and 67 and Table 9.

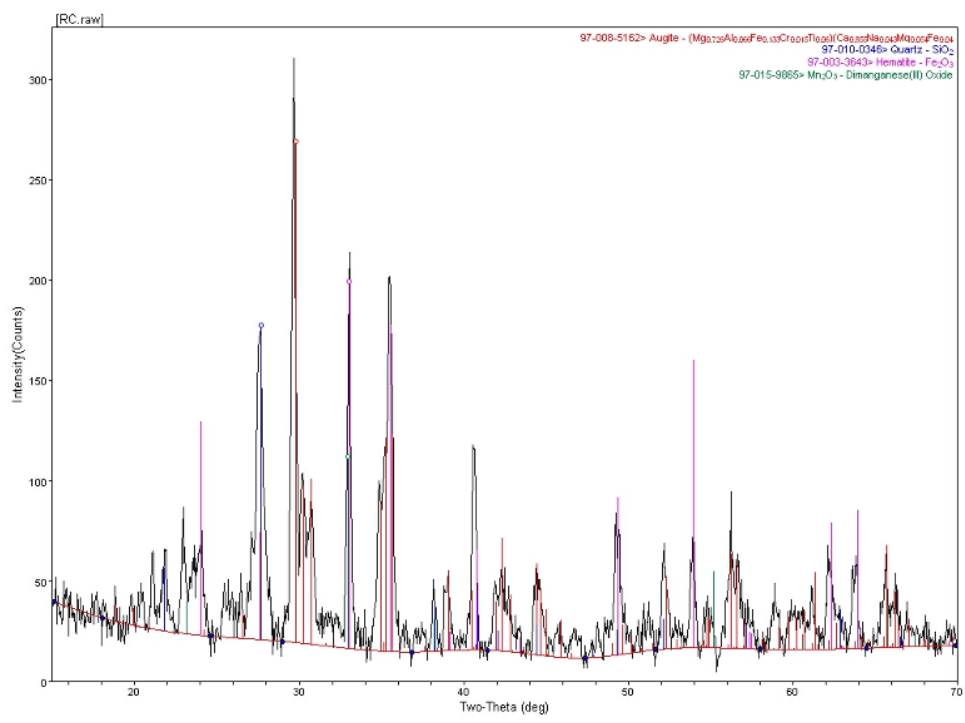

Figure 65. Jade element intensity results superimposed over XRD results for Pozzolan R2.

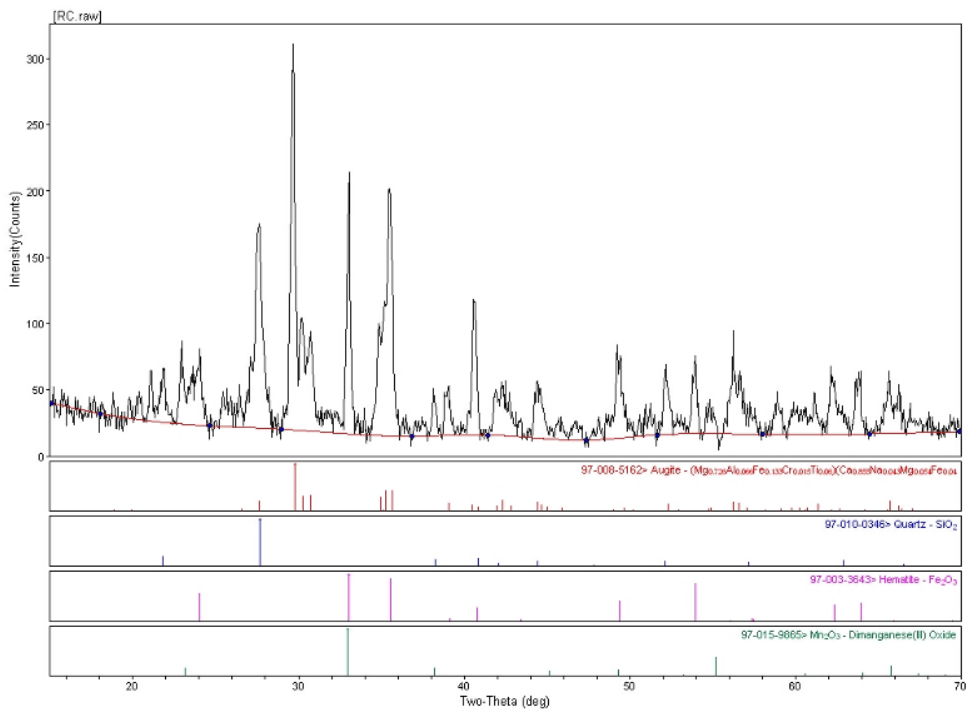

Figure 66. Location of major peak intensities of the elements in Pozzolan R2. 
Table 9. Composition of Pozzolan R2.

\begin{tabular}{|l|l|l|l|}
\hline Element & Chemical Formula & $\begin{array}{l}\text { Percent } \\
\text { by Weight }\end{array}$ & $\begin{array}{l}\text { Percent } \\
\text { by } \\
\text { Volume }\end{array}$ \\
\hline Augite & $\begin{array}{l}\left(\mathrm{Mg}_{0.726} \mathrm{Al}_{0.066} \mathrm{Fe}_{0.133} \mathrm{Cr}_{0.015} \mathrm{Ti}_{0.06}\right) \\
\left(\mathrm{Ca}_{0.855} \mathrm{Na}_{0.043} \mathrm{Mg}_{0.054} \mathrm{Fe}_{0.045} \mathrm{Mn}_{0.003}\right)\left(\mathrm{Si}_{1.773} \mathrm{Al}_{0.227} \mathrm{O}_{6}\right)\end{array}$ & 97.6 & 98.1 \\
\hline $\begin{array}{l}\text { Dimanganese(III) } \\
\text { oxide }\end{array}$ & $\mathrm{Mn}_{2} \mathrm{O}_{3}$ & 1.6 & 1.1 \\
\hline Quartz low & $\mathrm{SiO}_{2}$ & 0.5 & 0.6 \\
\hline Hematite & $\mathrm{Fe}_{2} \mathrm{O}_{3}$ & 0.3 & 0.2 \\
\hline
\end{tabular}

This sample is highly dominated by one constituent, similar to Pozzolan A, and meets the general expectation of high oxide content in pozzolan. The amounts do not exactly correspond with the pozzolans used in the tests reported above, but that is not surprising since the types differ.

\subsubsection{XRD results for fine variety (Pozzolan $R 1$ )}

This pozzolan did not closely match the reference compounds used in J ade's unrestricted search. Thus, a custom search had to be performed on the expected composition. This returned good results, as the oxides run matched well with the samples' XRD peaks. The results are shown in Figures 68 - 70 and Table 10.

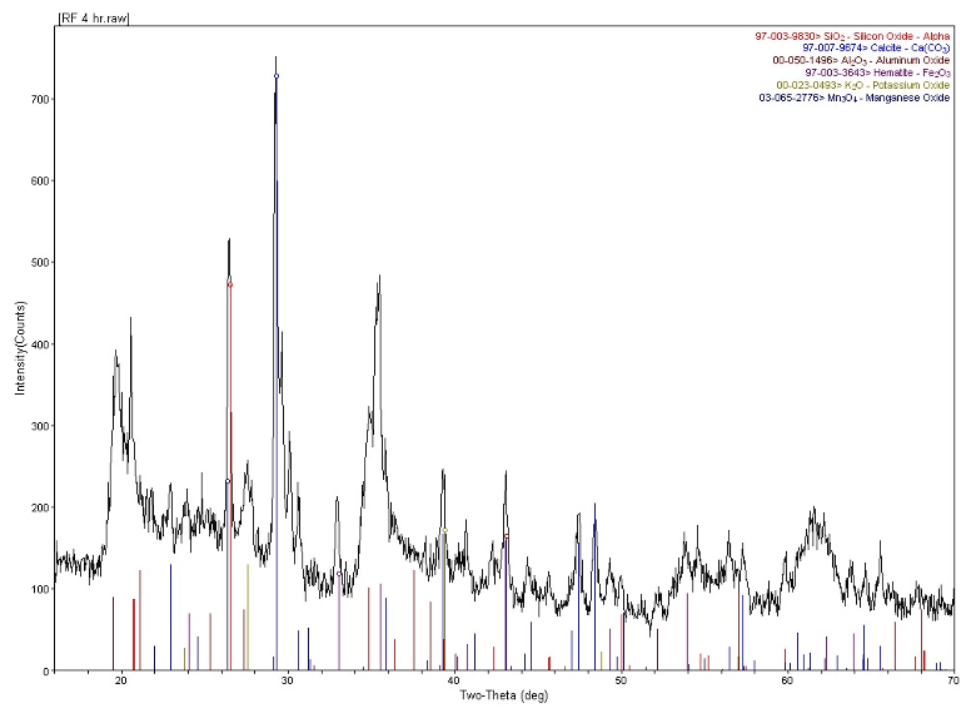

Figure 67. Jade element intensity results superimposed over XRD results for Pozzolan R1. 


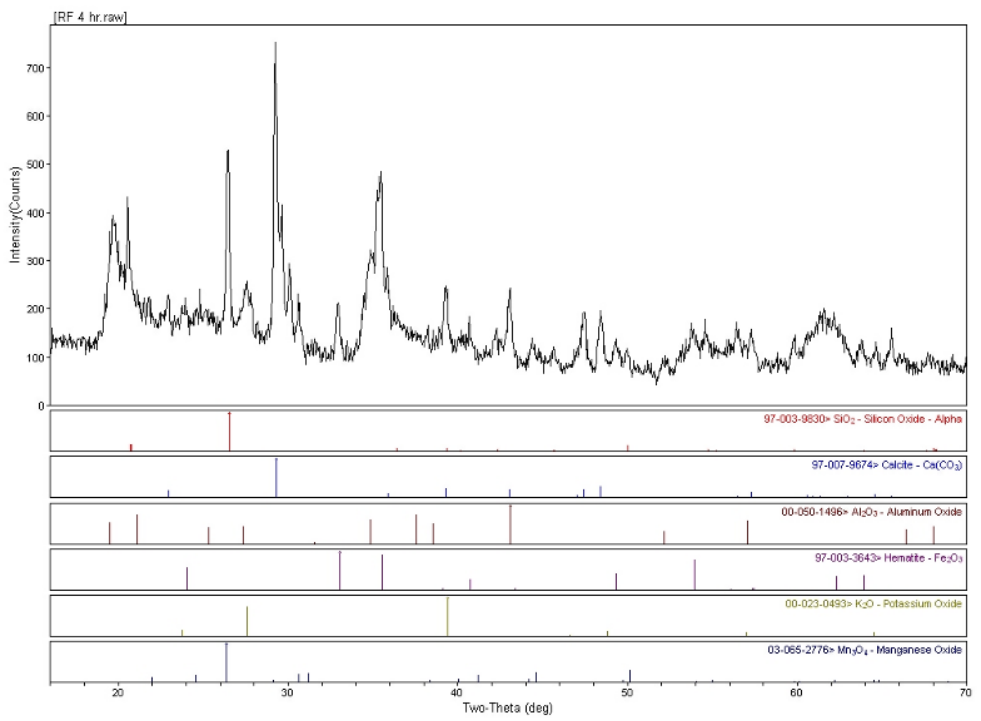

Figure 68. Location of major peak intensities of the elements in Pozzolan R1.

$\mathrm{SiO}_{2}<\mathrm{Wt} \%=64.6(37.5)>$

Calcite $-\mathrm{Ca}\left(\mathrm{CO}_{3}\right) \propto \mathrm{W} t \%=17.5(10.1)>$

$\mathrm{Al}_{2} \mathrm{O}_{3} \approx \mathrm{W} t \%=4.1(2.4)=$

Hematite $-\mathrm{Fe}_{2} \mathrm{O}_{3} \leq \mathrm{W} t \%=6.9(4.0)=$

$\mathrm{K}_{2} \mathrm{O}<\mathrm{W} \% \mathrm{H}=2.4(1.4)>$

$\mathrm{Mn}_{3} \mathrm{O}_{4} \approx \mathrm{WH} \%=4.4(2.6)=$

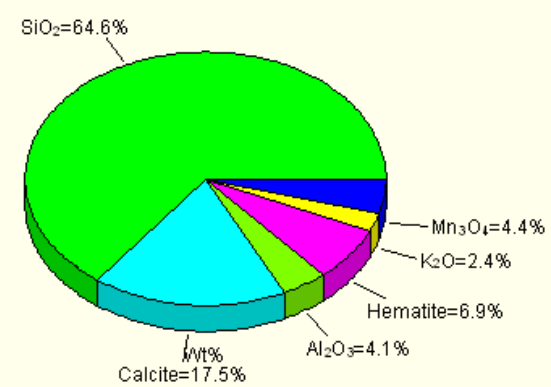

Figure 69. Graphical representation of components of Pozzolan R1.

Table 10. Composition of Pozzolan R1.

\begin{tabular}{|l|l|l|l|}
\hline Element & Chemical Formula & Percent by Weight & Percent by Volume \\
\hline Silicon oxide - alpha & $\mathrm{SiO}_{2}$ & 64.6 & 67.4 \\
\hline Calcite & $\mathrm{Ca}\left(\mathrm{CO}_{3}\right)$ & 17.5 & 17.8 \\
\hline Hematite & $\mathrm{Fe}_{2} \mathrm{O}_{3}$ & 6.9 & 3.6 \\
\hline Manganese oxide & $\mathrm{Mn}_{3} \mathrm{O}_{4}$ & 4.4 & 5.0 \\
\hline Aluminum oxide & $\mathrm{Al}_{2} \mathrm{O}_{3}$ & 4.1 & 3.3 \\
\hline Potassium oxide & $\mathrm{K}_{2} \mathrm{O}$ & 2.4 & 2.9 \\
\hline
\end{tabular}

Although this sample is dominated by one major compound, is contains a much higher percentage of other constituents than Pozzolan A and R2. The primary oxides, aluminum and silicon, are present as expected, but 
aluminum is present in much smaller quantities. All identified constituents are typical of pozzolans.

For perspective, it is worth restating that in a custom search such as the one used here, elements that are not specifically looked up may be present but remain unidentified. Previous knowledge of the sample and experience using J ade minimize this potential problem, however. By starting with a general search and then selecting only chemicals with excellent FOMs, the results can be considered accurate with a high level of confidence.

\subsection{Summary of failure patterns}

Figure 71 shows the failure pattern of all compression specimens tested. Overall, two main patterns were observed: conical failure and shear failure. Table 11 summarizes the data obtained from the compression testing, with all relevant background and engineering data.

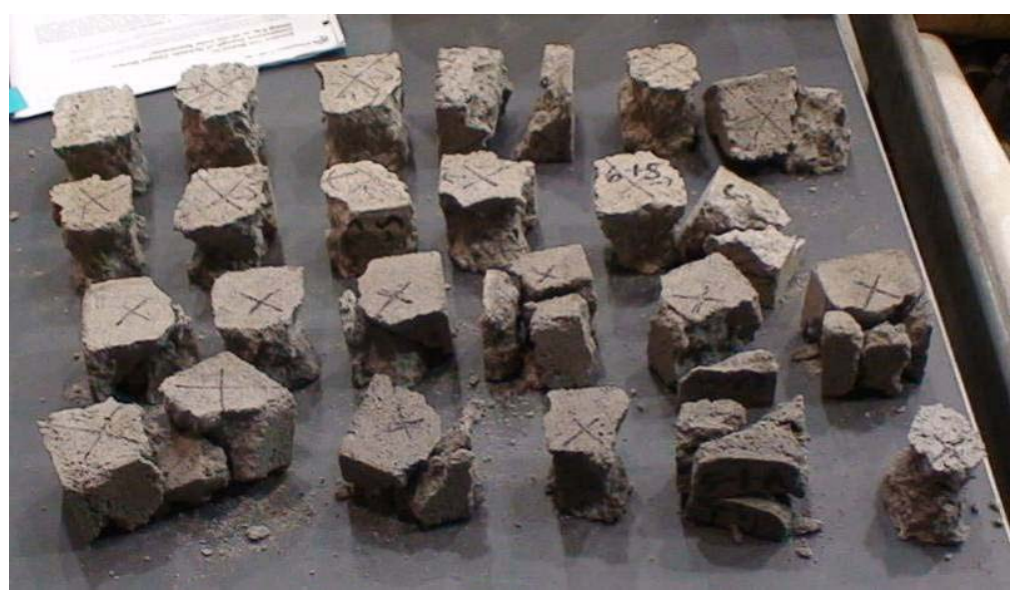

Figure 70. Failure pattern of all specimens. 
Table 11. Summary of compressive testing for all mortar cubes containing pozzolan.

\begin{tabular}{|l|l|l|l|l|l|l|l|}
\hline Cube & Area (in $\left.{ }^{2}\right)$ & $\begin{array}{l}\text { Ultimate } \\
\text { Stress (psi) }\end{array}$ & $\begin{array}{l}\text { Ultimate } \\
\text { Strain }\end{array}$ & $\begin{array}{l}\% \text { Diff } \\
\text { w/control }\end{array}$ & $\begin{array}{l}\text { Modulus } \\
\text { (ksi) }\end{array}$ & $\begin{array}{l}\% \text { Diff } \\
\text { w/control }\end{array}$ & Remarks \\
\hline 1-1-S & 4.10 & 2545 & 0.00161 & $45 \%$ & 1581 & $-31 \%$ & $\begin{array}{l}\text { Loss of strain at } \\
\text { beginning }\end{array}$ \\
\hline 2-1-S & 4.06 & 1925 & 0.00275 & $148 \%$ & 700 & $-60 \%$ & \\
\hline 3-1-S & 4.19 & 802 & 0.00248 & $123 \%$ & 323 & $-55 \%$ & \\
\hline 4-1-S & 4.05 & 457 & 0.00313 & $182 \%$ & 146 & $-65 \%$ & \\
\hline 5-1-S & 4.07 & 402 & 0.00309 & $178 \%$ & 130 & $-64 \%$ & \\
\hline $6-2-S$ & 3.97 & 313 & 0.00050 & $-55 \%$ & 626 & $122 \%$ & Broke in 10 seconds \\
\hline 1-1-G & 4.04 & 888 & 0.00171 & $54 \%$ & 519 & $-35 \%$ & \\
\hline 2-1-G & 4.05 & 750 & 0.00221 & $99 \%$ & 339 & $-50 \%$ & Broke in 10 seconds \\
\hline 3-1-G & 4.01 & 821 & 0.00229 & $106 \%$ & 359 & $-51 \%$ & \\
\hline $4-1-G$ & 4.19 & 177 & 0.00006 & $-95 \%$ & 2899 & $1720 \%$ & $\begin{array}{l}\text { Unexpected shape } \\
\text { of curve }\end{array}$ \\
\hline 5-1-G & 4.05 & 300 & 0.00208 & $87 \%$ & 144 & $-47 \%$ & \\
\hline $6-1-G$ & 4.11 & 330 & 0.00361 & $225 \%$ & 91 & $-69 \%$ & \\
\hline 1-1-A & 4.06 & 644 & 0.00202 & $82 \%$ & 319 & $-45 \%$ & \\
\hline 2-1-A & 4.17 & 418 & 0.00398 & $258 \%$ & 105 & $-72 \%$ & \\
\hline 3-1-A & 4.04 & 639 & 0.00222 & $100 \%$ & 288 & $-50 \%$ & \\
\hline $4-1-A$ & 4.03 & 451 & 0.00179 & $61 \%$ & 252 & $-38 \%$ & $\begin{array}{l}\text { Loss of strain at } \\
\text { beginning }\end{array}$ \\
\hline 5-1-A & 4.07 & 478 & 0.00083 & $-25 \%$ & 576 & $34 \%$ & \\
\hline 6-1-A & 4.08 & 424 & 0.00144 & $30 \%$ & 294 & $-23 \%$ & $\begin{array}{l}\text { Unexpected shape } \\
\text { of curve }\end{array}$ \\
\hline
\end{tabular}

Note: Pozzolan R cubes were not fabricated or tested because that pozzolan has no commercial potential due to its rarity and impurities. 


\section{Characteristics of Concrete Formulated With Pozzolan Additives}

\subsection{Concrete formulation components}

\subsubsection{Pozzolanic materials}

For this investigation, pozzolanic materials were selected based on their conformance with ASTM C618, Standard Specification for Coal Fly Ash and Raw or Calcined Natural Pozzolan for Use in Concrete. Natural pozzolan was used from three sources:

- Saudi Arabia (Pozzolan S1)

- South Africa (Pozzolan S2)

- J ordan (Pozzolan J)

This phase of testing also included Class F fly ash, a human-made pozzolan that is a residue of the combustion of finely ground coal used in electric power generation. This industrial pozzolan is well characterized, and is one of the two fly ash classes specified in ASTM C618.

The natural pozzolan samples were extracted, crushed, ground, and tested. A Cilas Granulometre 715 device was used to determine the grain size distribution of the materials. Tables 12 and 13 show the chemical composition, loss on ignition, density, fineness, and grain size distribution of the selected pozzolans.

Table 12. Analysis of pozzolanic materials.

\begin{tabular}{|l|l|l|l|l|}
\hline Determinate & Fly Ash & Pozzolan J & Pozzolan S1 & Pozzolan S2 \\
\hline $\mathrm{SiO}_{2}(\%)$ & 51.06 & 42.56 & 48.44 & 44.7 \\
\hline $\mathrm{Al}_{2} \mathrm{O}_{3}(\%)$ & 32.23 & 13.55 & 15.97 & 14.5 \\
\hline $\mathrm{CaO}(\%)$ & 4.18 & 9.75 & 8.53 & 9 \\
\hline $\mathrm{Fe}_{2} \mathrm{O}_{3}(\%)$ & 3.42 & 13.24 & 13.2 & 11.8 \\
\hline $\mathrm{MgO}(\%)$ & 1.06 & 11.15 & 7.89 & 7.8 \\
\hline $\mathrm{SO}_{3}(\%)$ & 0.42 & 0.35 & 0.1 & 0.15 \\
\hline $\mathrm{TiO}_{2}(\%)$ & 1.70 & 2.54 & - & - \\
\hline $\mathrm{K}_{2} \mathrm{O}(\%)$ & 0.58 & 1.17 & 1.37 & 1.3 \\
\hline $\mathrm{Mn}_{2} \mathrm{O}_{3}(\%)$ & 0.01 & 0.14 & - & - \\
\hline $\mathrm{Na}_{2} \mathrm{O}(\%)$ & - & - & - & 3.4 \\
\hline
\end{tabular}




\begin{tabular}{|l|l|l|l|l|}
\hline Determinate & Fly Ash & Pozzolan J & Pozzolan S1 & Pozzolan S2 \\
\hline Water Requirement (\%) & 90 & 100 & 100 & 100 \\
\hline Free Water (\%) & 0.1 & 0.1 & 0.1 & 0.1 \\
\hline Loss on Ignition (\%) & 0.81 & 2.56 & 1.26 & 1.5 \\
\hline Blaine Fineness $\left(\mathrm{m}^{2} / \mathrm{kg}\right)$ & 238 & 461 & 320 & 564 \\
\hline Density $\left(\mathrm{g} / \mathrm{cm}^{3}\right)$ & 2.20 & 2.86 & 2.8 & 2.8 \\
\hline
\end{tabular}

Table 13. Grain size distribution of pozzolanic materials.

\begin{tabular}{|l|l|l|l|l|}
\hline \multirow{2}{*}{ Opening Size $(\mu \mathrm{m})$} & \multicolumn{4}{|l|}{ \%eight retained } \\
\cline { 2 - 5 } & Fly Ash & Pozzolan J & Pozzolan S1 & Pozzolan S2 \\
\hline 1 & 92.2 & 93.4 & 96.4 & 93.5 \\
\hline 1.5 & 90.0 & 90.6 & 94.9 & 90.5 \\
\hline 2. & 85.5 & 84.2 & 90.8 & 82.5 \\
\hline 3 & 78.8 & 78.4 & 87.1 & 75.5 \\
\hline 4 & 72.0 & 74.2 & 83.6 & 69.9 \\
\hline 6 & 59.9 & 67.1 & 78.3 & 60 \\
\hline 8 & 51.2 & 61.1 & 72.4 & 50.5 \\
\hline 12 & 36.9 & 51.3 & 63.2 & 36.6 \\
\hline 16 & 27.5 & 43.0 & 51.2 & 24.4 \\
\hline 24 & 15.1 & 30.6 & 34.5 & 12.8 \\
\hline 32 & 10.3 & 21.0 & 19.7 & 5.9 \\
\hline 48 & 3.3 & 7.3 & 5.3 & 1.6 \\
\hline 64 & 3.1 & 3.5 & 0 & 0 \\
\hline 96 & 0.0 & 0.0 & 0 & 0 \\
\hline 128 & 0.0 & 0.0 & 0 & 0 \\
\hline 192 & 0.0 & 0.0 & 0 & 0 \\
\hline
\end{tabular}

\subsubsection{Portland cement}

Type I Portland cement with a class strength of $42.5 \mathrm{MPa}$ was used in the production of the concrete mixes. The chemical properties of the cement were periodically tested in the laboratory. The chemical composition, loss on ignition, fineness, and particle size distribution are shown in Tables 14 and 15. 
Table 14. Chemical composition of Portland cement.

\begin{tabular}{|c|c|c|}
\hline Determinate & Portland cement & $\begin{array}{l}\text { Type I ASTM C150 Chemical } \\
\text { Requirements (max) }\end{array}$ \\
\hline $\mathrm{CaO}(\%)$ & 64.94 & $63^{a}$ \\
\hline $\mathrm{SiO}_{2}(\%)$ & 20 & $22^{a}$ \\
\hline $\mathrm{Al}_{2} \mathrm{O}_{3}(\%)$ & 5.68 & --- \\
\hline $\mathrm{Fe}_{2} \mathrm{O}_{3}(\%)$ & 3.98 & --- \\
\hline MgO (\%) & 0.7 & 6.0 \\
\hline $\mathrm{SO}_{3}(\%)$ & 2.81 & $3.5^{b}$ \\
\hline $\mathrm{Na}_{2} \mathrm{O}+0.685 \mathrm{~K}_{2} \mathrm{O}(\%)$ & 0.21 & 0.60 \\
\hline Loss on Ignition (\%) & 1.16 & 3.0 \\
\hline Insoluble Residue (\%) & 0.32 & 0.75 \\
\hline $\begin{array}{l}\text { Blaine Fineness } \\
\left(\mathrm{m}^{2} / \mathrm{kg}\right)\end{array}$ & 320 & 260 \\
\hline \multicolumn{3}{|c|}{$\begin{array}{l}\text { a Typical value (Mindess 1981). } \\
\text { b When Tricalcium aluminate is more than } 8 \% \text {. (Tricalcium aluminate }=2.650 * \% \mathrm{Al}_{2} \mathrm{O}_{3}-1.692 \\
* \% \mathrm{Fe}_{2} \mathrm{O}_{3}=2.650 * 5.68-1.692 * 3.98=8.32 \text { ). }\end{array}$} \\
\hline
\end{tabular}

Table 15. Particle size distribution of Portland cement.

\begin{tabular}{|l|l|}
\hline Cilas sieves $(\mu \mathrm{m})$ & \% Retained \\
\hline 1 & 95.6 \\
\hline 1.5 & 94.5 \\
\hline 2. & 92.7 \\
\hline 3 & 89.8 \\
\hline 4 & 86.4 \\
\hline 6 & 79.3 \\
\hline 8 & 74.0 \\
\hline 12 & 63.0 \\
\hline 16 & 53.6 \\
\hline 24 & 37.1 \\
\hline 32 & 26.8 \\
\hline 48 & 11.2 \\
\hline 64 & 6.7 \\
\hline 96 & 0.0 \\
\hline 128 & 0.0 \\
\hline 192 & 0.0 \\
\hline
\end{tabular}

\subsubsection{Aggregate materials}

The selected aggregates were crushed basalt rocks from a basalt quarry. The crushed aggregates were sifted using sieves ranging in size from $1 \mathrm{~mm}$ 
to $150 \mu \mathrm{m}$ (\#200), as summarized in Tables 16 and 17 and Figures 72 and 73. The grain size distribution of the aggregates is shown in Table 18. The graded sand that was used was basalt aggregate crushed to the sizes shown in

Table 19 and Figure 74. After the aggregate was separated into the various sieve sizes, each size was washed with water over the sieve to remove adhering dust and fine particles from the aggregate. The portions retained on the sieve were dried and stored in clean containers.

Table 16. Sifting of $3 / 4$ inch aggregate.

\begin{tabular}{|l|l|l|l|l|l|}
\hline \multicolumn{2}{|l|}{ Plant } & Riyadh & \multicolumn{2}{l|}{ Location in Riyadh } & Sulay \\
\hline Source & & Mozamiah & \multicolumn{2}{l|}{ Sample Description } & $3 / 4 "$ \\
\hline Date Sampled & & 01.12 .2007$. & Wt. Of Dry Washed Sample & 2012.0 \\
\hline Date Tested & & 03.12 .2007$. & Weight of Dry Sample & 2015.0 \\
\hline Sieve Size & & $\begin{array}{l}\text { Mass } \\
\text { Retained }\end{array}$ & $\begin{array}{l}\text { Cum. Mass } \\
\text { Retained }\end{array}$ & $\begin{array}{l}\text { Cum. } \\
\text { Percent } \\
\text { Retained }\end{array}$ & $\begin{array}{l}\text { Percent } \\
\text { Passing }\end{array}$ \\
\hline Inch. & $\mathrm{mm}$. & $(\mathrm{Gm})$. & $($ Gm.) & $(\%)$ & $(\%)$ \\
\hline 1 & 25.00 & 0.0 & 0.0 & 0.0 & 100.0 \\
\hline $3 / 4$ & 19.00 & 106.0 & 106.0 & 5.3 & 94.7 \\
\hline $1 / 2$ & 12.50 & 1182.0 & 1288.0 & 63.9 & 36.1 \\
\hline $3 / 8$ & 9.50 & 608.0 & 1896.0 & 94.1 & 5.9 \\
\hline$\# 4$ & 4.75 & 114.0 & 2010.0 & 99.8 & 0.2 \\
\hline$\# 8$ & 2.36 & 0.0 & 2010.0 & 99.8 & 0.2 \\
\hline$\# 16$ & 1.18 & 1.0 & 2011.0 & 99.8 & 0.2 \\
\hline \# 200 & 0.075 & 1.0 & 2012.0 & 99.9 & 0.1 \\
\hline
\end{tabular}




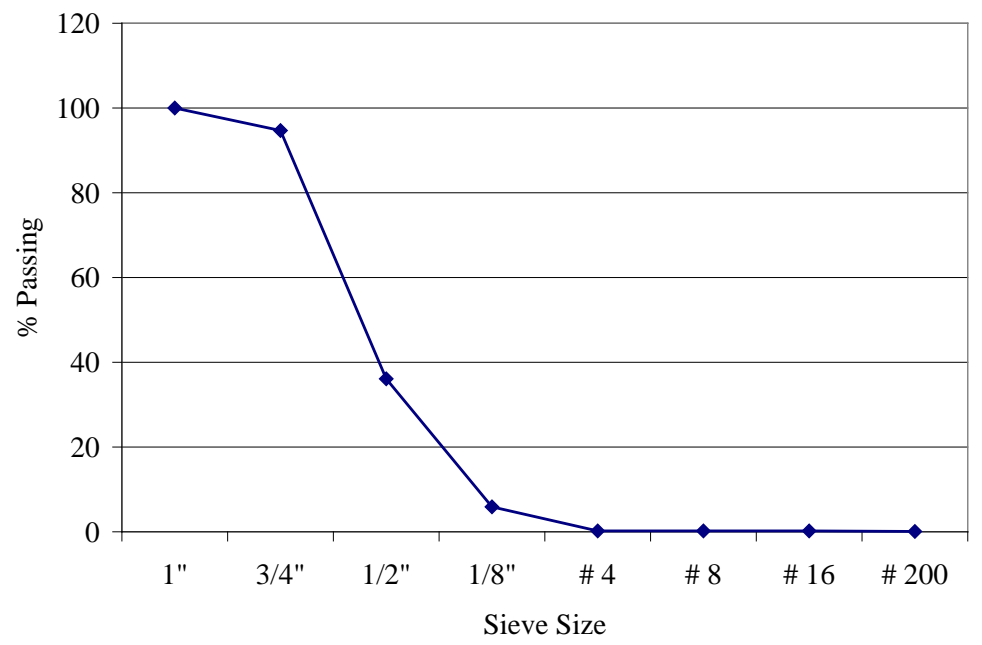

Figure 71 . Sifting of $3 / 4$ inch aggregate.

Table 17. Sifting of $3 / 8$ inch aggregate.

\begin{tabular}{|c|c|c|c|c|c|}
\hline \multicolumn{2}{|l|}{ Plant } & Riyadh & \multicolumn{2}{|c|}{ Location in Riyadh } & Sulay \\
\hline \multicolumn{2}{|c|}{ Source } & Mozamiah & \multicolumn{2}{|c|}{ Sample Description } & $3 / 8^{\prime \prime}$ \\
\hline \multicolumn{2}{|c|}{ Date Sampled } & 01.12 .2007 & \multicolumn{2}{|c|}{ Wt. Of Dry Washed Sample } & 1195.0 \\
\hline \multicolumn{2}{|c|}{ Date Tested } & 03.12 .2007 & \multicolumn{2}{|c|}{ Weight of Dry Sample } & 1202.0 \\
\hline \multicolumn{2}{|c|}{ Sieve Size } & Mass Retained & $\begin{array}{l}\text { Cum. Mass } \\
\text { Retained }\end{array}$ & $\begin{array}{l}\text { Cum. Percent } \\
\text { Retained }\end{array}$ & $\begin{array}{l}\text { Percent } \\
\text { Passing }\end{array}$ \\
\hline Inch. & $\mathrm{mm}$. & (Gm.) & (Gm.) & $(\%)$ & $(\%)$ \\
\hline 1 & 25.00 & 0.0 & 0.0 & 0.0 & 100.0 \\
\hline $3 / 4$ & 19.00 & 0.0 & 0.0 & 0.0 & 100.0 \\
\hline $1 / 2$ & 12.50 & 0.0 & 0.0 & 0.0 & 100.0 \\
\hline $3 / 8$ & 9.50 & 96.0 & 96.0 & 8.0 & 92.0 \\
\hline$\# 4$ & 4.75 & 70.0 & 166.0 & 13.8 & 86.2 \\
\hline$\# 8$ & 2.36 & 993.0 & 1159.0 & 96.4 & 3.6 \\
\hline \# 16 & 1.18 & 34.0 & 1193.0 & 99.3 & 0.7 \\
\hline \# 200 & 0.075 & 1.0 & 1194.0 & 99.3 & 0.7 \\
\hline
\end{tabular}




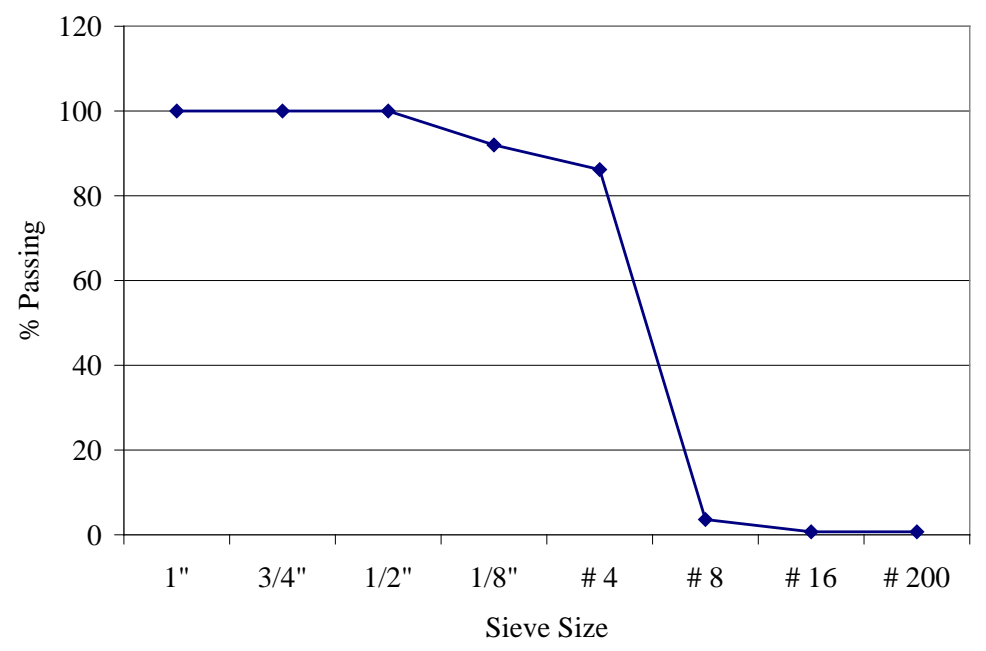

Figure 72 . Sifting of $3 / 8$ inch aggregate.

Table 18. Grain size distribution of basalt aggregate.

\begin{tabular}{|l|l|}
\hline Sieve Size & \% Used \\
\hline No. 16 - No. 30 & 5 \\
\hline No. 30 - No. 40 & 30 \\
\hline No. 40 - No. 50 & 42 \\
\hline No. 50 - No. 100 & 23 \\
\hline
\end{tabular}

Table 19. Sifting of fine silica sand.

\begin{tabular}{|c|c|c|c|c|c|}
\hline \multicolumn{2}{|l|}{ Plant } & Riyadh & \multicolumn{2}{|c|}{ Location in Riyadh } & Sulay \\
\hline \multicolumn{2}{|c|}{ Source } & Al Kharj Road & \multicolumn{2}{|c|}{ Sample Description } & F. Sand \\
\hline \multicolumn{2}{|c|}{ Date Sampled } & 01.12 .2008 & \multicolumn{2}{|c|}{ Wt. Of Dry Washed Sample } & 838.0 \\
\hline \multicolumn{2}{|c|}{ Date Tested } & 03.12 .2008 & \multicolumn{2}{|c|}{ Weight of Dry Sample } & 840.0 \\
\hline \multicolumn{2}{|c|}{ Sieve Size } & Mass Retained & $\begin{array}{l}\text { Cum. Mass } \\
\text { Retained }\end{array}$ & $\begin{array}{l}\text { Cum. Percent } \\
\text { Retained }\end{array}$ & $\begin{array}{l}\text { Percent } \\
\text { Passing }\end{array}$ \\
\hline Inch. & $\mathrm{mm}$. & (Gm.) & (Gm.) & $(\%)$ & (\%) \\
\hline $3 / 8 "$ & 10.00 & 0.0 & 0.0 & 0.0 & 100.0 \\
\hline \# 4 & 4.75 & 0.0 & 0.0 & 0.0 & 100.0 \\
\hline \# 8 & 2.36 & 0.0 & 0.0 & 0.0 & 100.0 \\
\hline \# 16 & 1.18 & 1.0 & 1.0 & 0.1 & 99.9 \\
\hline$\# 30$ & 0.600 & 8.0 & 9.0 & 1.1 & 98.9 \\
\hline$\# 50$ & 0.300 & 344.0 & 353.0 & 42.0 & 58.0 \\
\hline$\# 100$ & 0.150 & 354.0 & 707.0 & 84.2 & 15.8 \\
\hline$\# 200$ & 0.075 & 131.0 & 838.0 & 99.8 & 0.2 \\
\hline
\end{tabular}




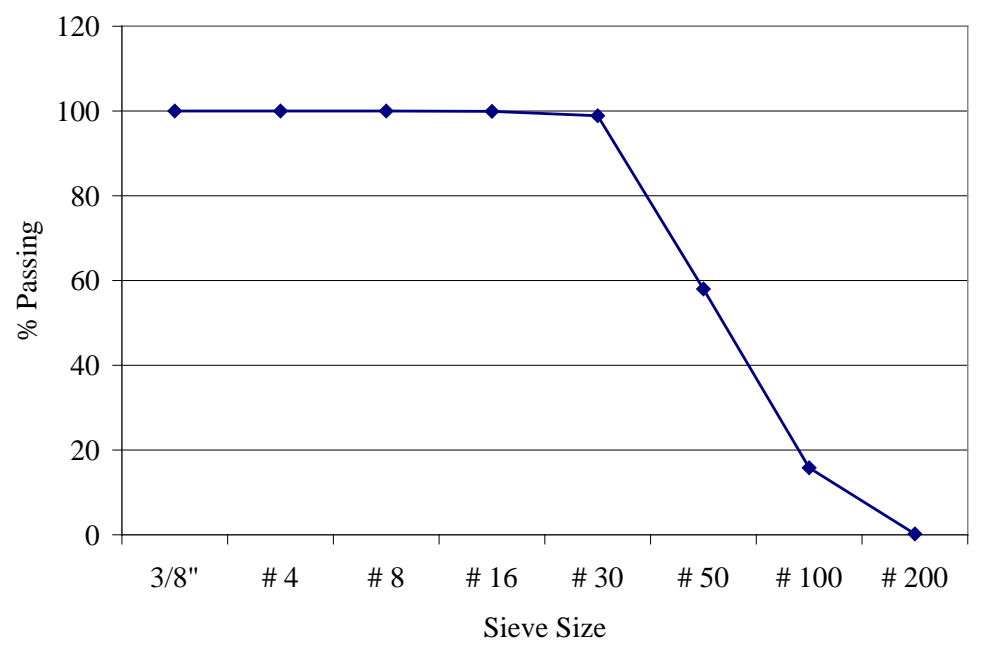

Figure 73. Sifting of fine silica sand.

\subsection{Compressive strength testing}

This investigation was carried out under laboratory conditions using procedures outlined by ASTM C109/C109M. The objective was to evaluate the effect of the different pozzolanic materials, as substituted for Portland cement, on the compressive strength of concrete. The results are presented as a comparison between the control specimen compressive strength and the strength of the test specimens by percent of pozzolan used.

The test specimens ( $50 \times 50 \times 50 \mathrm{~mm}$ prisms) were molded from a control mixture and the test mixtures in accordance with ASTM C109/ C109M. The test mixtures used mineral admixtures to replace 10, 15, 20, 25, 30, and $40 \%$ of the mass of the Portland cement used in the control mixture.

The control mixture consisted of:

- $500 \mathrm{~g}$ of Portland cement

- $1375 \mathrm{~g}$ of graded standard sand (ASTM C778)

- $242 \mathrm{ml}$ of water.

The test mixtures consisted of:

- $450,425,400,375,350,300 \mathrm{~g}$ of Portland cement

- 50, 75, 100, 125, 150, 200 g of mineral admixtures

- $1375 \mathrm{~g}$ of graded standard sand

- $242 \mathrm{ml}$ of water. 
The dry materials for the test mortar were prepared using 1 part cement to 2.75 parts of graded aggregate by mass to cast the test prisms. A water-tocement ratio equal to 0.485 by mass was used. The concrete mixes for the control specimens and specimens with $10 \%$ are shown in Tables 20 and 21 .

After the dry mixtures were prepared, the specimens were mechanically mixed in accordance with ASTM C305, Standard Practice for Mechanical Mixing of Hydraulic Cement Pastes and Mortars of Plastic Consistency. The prisms were molded immediately after the mixing was finished, and they were placed and tamped as required by ASTM C109/ 109M. Immediately upon completion of the molding, the specimens were placed in a moist room at $23.0 \pm 2.0^{\circ} \mathrm{C}$ for 24 hours. As specified in ASTM $\mathrm{C} 109 / \mathrm{C} 109 \mathrm{M}$, the prisms were removed from the moist room and placed in water storage tanks. The compressive strengths of two specimens of the control mixture and two specimens of each test mixture were determined at curing durations of 7, 28, 90, and 180 days. Tables $22-29$ and Figures 75 - 83 show the results, which demonstrate that the natural pozzolans produce strengths similar to the fly ash.

Table 20. Mixture for control specimen.

\begin{tabular}{|c|c|c|c|c|c|}
\hline \multirow{3}{*}{$\begin{array}{l}\text { Mix: c } 35 \\
\text { Lab-233 }\end{array}$} & \multicolumn{4}{|c|}{ Laboratory trial mix } & \multirow[b]{2}{*}{0.50} \\
\hline & \multicolumn{2}{|c|}{ Pozzolan replacement } & \multirow{2}{*}{\begin{tabular}{|l|}
$0 \%$ \\
Dated \\
\end{tabular}} & $\mathrm{W} / \mathrm{c}$ & \\
\hline & & [i] & & \multicolumn{2}{|c|}{ Jan. 042009} \\
\hline Ingredients & & 1 & M3 wt & 0.03 & M3 wt \\
\hline O.P.C. & & 350 & Kgs. & 10.5 & Kgs. \\
\hline Pozzolan & & 0 & $"$ & 0 & $"$ \\
\hline $3 / 4 "$ & & 745 & $"$ & 22.35 & $"$ \\
\hline $3 / 8 "$ & & 436 & $"$ & 13.08 & $"$ \\
\hline F. Sand & & 636 & $"$ & 19.08 & $"$ \\
\hline Free water & & 175 & Ltrs. & 5.25 & Ltrs. \\
\hline Total wager & & 188.4 & $"$ & 5.652 & $"$ \\
\hline $\operatorname{Pr}-150$ & & 2.1 & $"$ & 0.063 & $"$ \\
\hline Slump retention & $\mathrm{Mm}$ & & Temperature & & $\mathrm{Oc}$ \\
\hline Initial & 170 & & Water & & 16.0 \\
\hline 30 minutes & 120 & & Ambient & & 15.0 \\
\hline 45 minutes & 105 & & Concrete(i) & & 20.5 \\
\hline 60 minutes & 95 & & Concrete(f) & & 19.5 \\
\hline
\end{tabular}


Table 21. Mixture for specimen with $10 \%$ pozzolan.

\begin{tabular}{|c|c|c|c|c|c|}
\hline \multirow{4}{*}{$\begin{array}{l}\text { Mix: c } 35 \\
\text { Lab-000 } \\
\text { Ingredients }\end{array}$} & \multicolumn{4}{|c|}{ Laboratory trial mix } & \multirow[b]{2}{*}{0.45} \\
\hline & \multicolumn{2}{|c|}{ Pozzolan replacement } & \multirow{2}{*}{\begin{tabular}{|l|}
$0 \%$ \\
Dated \\
\end{tabular}} & $\mathrm{W} / \mathrm{c}$ & \\
\hline & {$[\mathrm{ii}]$} & & & \multicolumn{2}{|c|}{ Jan. 042009} \\
\hline & & 1 & M3 wt & 0.03 & M3 WT \\
\hline O. P. C. & & 280 & Kgs. & 8.4 & KGS. \\
\hline Pozzolan & & 70 & $"$ & 2.1 & " \\
\hline $3 / 4 "$ & & 764 & $"$ & 22.92 & $"$ \\
\hline $3 / 8^{\prime \prime}$ & & 447 & $"$ & 13.41 & $"$ \\
\hline F. Sand & & 652 & $"$ & 19.56 & $"$ \\
\hline Free water & & 157.3 & Ltrs. & 4.719 & Ltrs. \\
\hline Total wager & & 171.3 & $"$ & 5.139 & $"$ \\
\hline $\operatorname{Pr}-150$ & & 2.1 & $"$ & 0.063 & $"$ \\
\hline Slump retention & $\mathrm{Mm}$ & & Temperature & & $\mathrm{OC}$ \\
\hline Initial & 50 & & Water & & 16.0 \\
\hline 30 minutes & & & Ambient & & 16.8 \\
\hline 45 minutes & & & Concrete(i) & & 20.0 \\
\hline 60 minutes & & & Concrete(f) & & - \\
\hline
\end{tabular}

Table 22. Compressive strength of control and test specimens with fly ash.

\begin{tabular}{|l|l|l|l|l|}
\hline \multirow{2}{*}{$\begin{array}{l}\text { Portland cement } \\
\text { replacement \% }\end{array}$} & \multicolumn{4}{|l|}{ Compressive strength (MPa) } \\
\cline { 2 - 5 } & 7 Days & 28 Days & 90 Days & 180 Days \\
\hline 0 & 6.1 & 10.5 & 10.7 & 12.5 \\
\hline 10 & 4.1 & 7.1 & 7.2 & 9.1 \\
\hline 15 & 6.1 & 10.1 & 10.2 & 14.2 \\
\hline 20 & 7.9 & 9.9 & 15.2 & 15.1 \\
\hline 25 & 6.9 & 10.1 & 13 & 13.1 \\
\hline 30 & 6.15 & 10.8 & 15.8 & 15 \\
\hline 40 & 7.3 & 9.5 & 11.8 & 16.2 \\
\hline
\end{tabular}




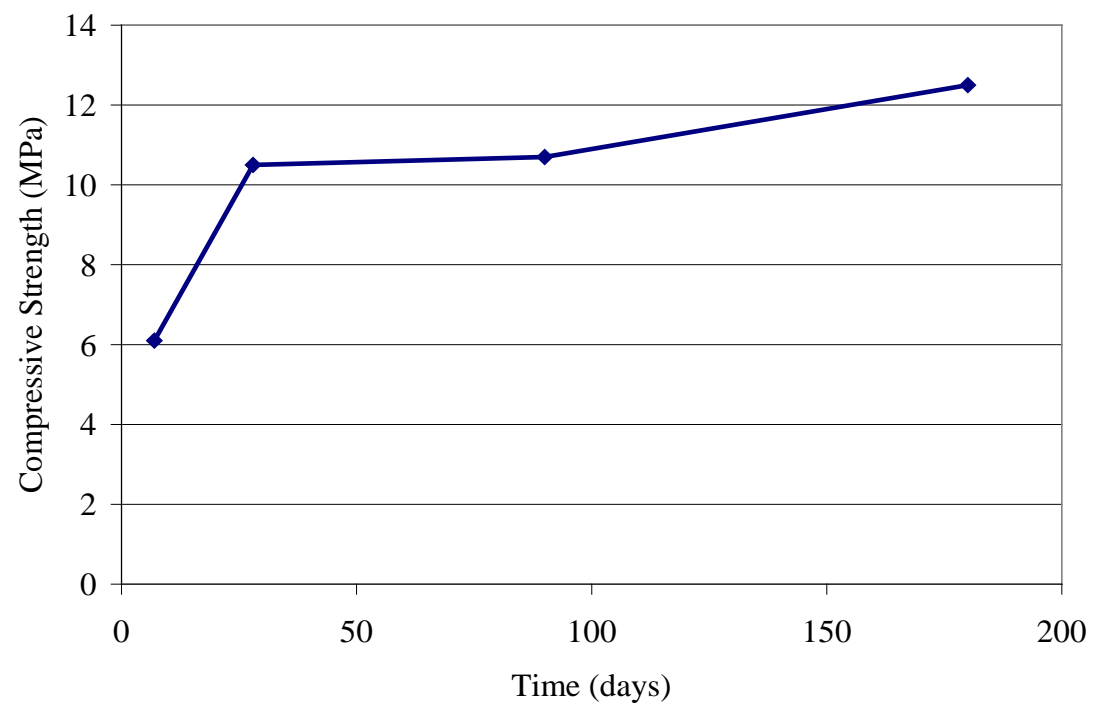

Figure 74. Compressive strength of control specimen.

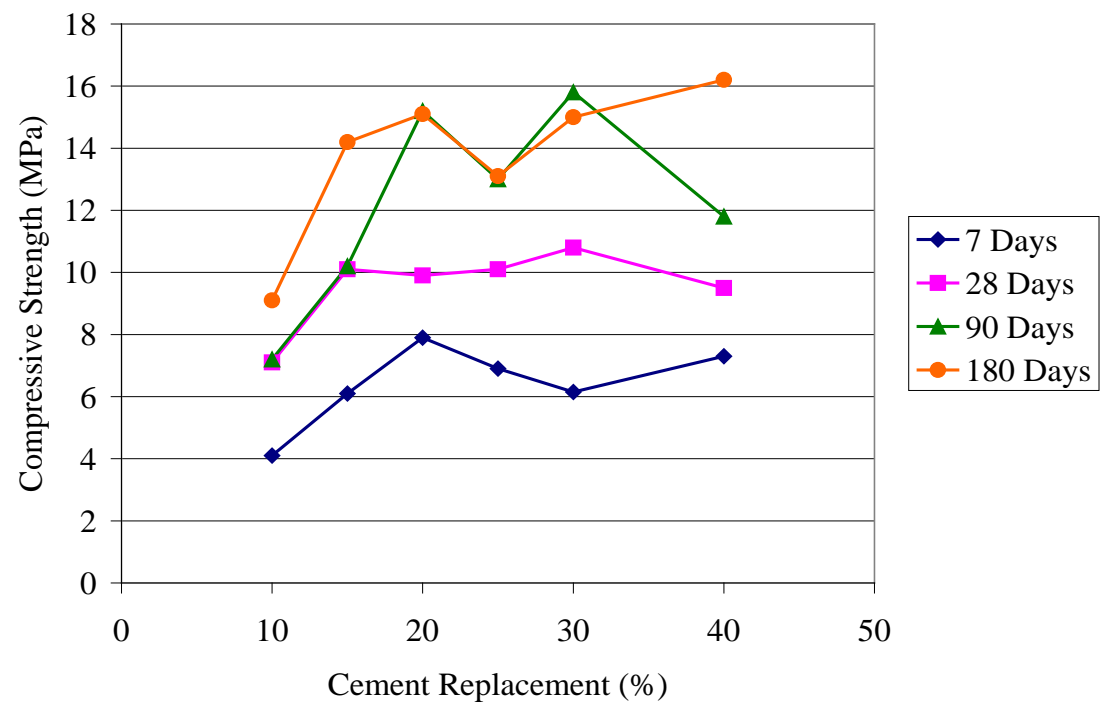

Figure 75. Compressive strength of test specimens with fly ash.

Table 23. Compressive strength of test specimens with Pozzolan J.

\begin{tabular}{|l|l|l|l|l|}
\hline \multirow{2}{*}{$\begin{array}{l}\text { Portland cement } \\
\text { replacement \% }\end{array}$} & \multicolumn{4}{|l|}{ Compressive strength $(\mathbf{M P a})$} \\
\cline { 2 - 5 } & $\mathbf{7}$ Days & $\mathbf{2 8}$ Days & $\mathbf{9 0}$ Days & $\mathbf{1 8 0}$ Days \\
\hline 10 & 8 & 11 & 11.7 & 13.7 \\
\hline 15 & 8.2 & 11.2 & 13 & 13.2 \\
\hline 20 & 6.7 & 10.3 & 11.5 & 11.7 \\
\hline 25 & 7.5 & 11.5 & 11.1 & 14.7 \\
\hline 30 & 8.3 & 10 & 12.1 & 15 \\
\hline 40 & 7.2 & 9.5 & 12.2 & 14 \\
\hline
\end{tabular}




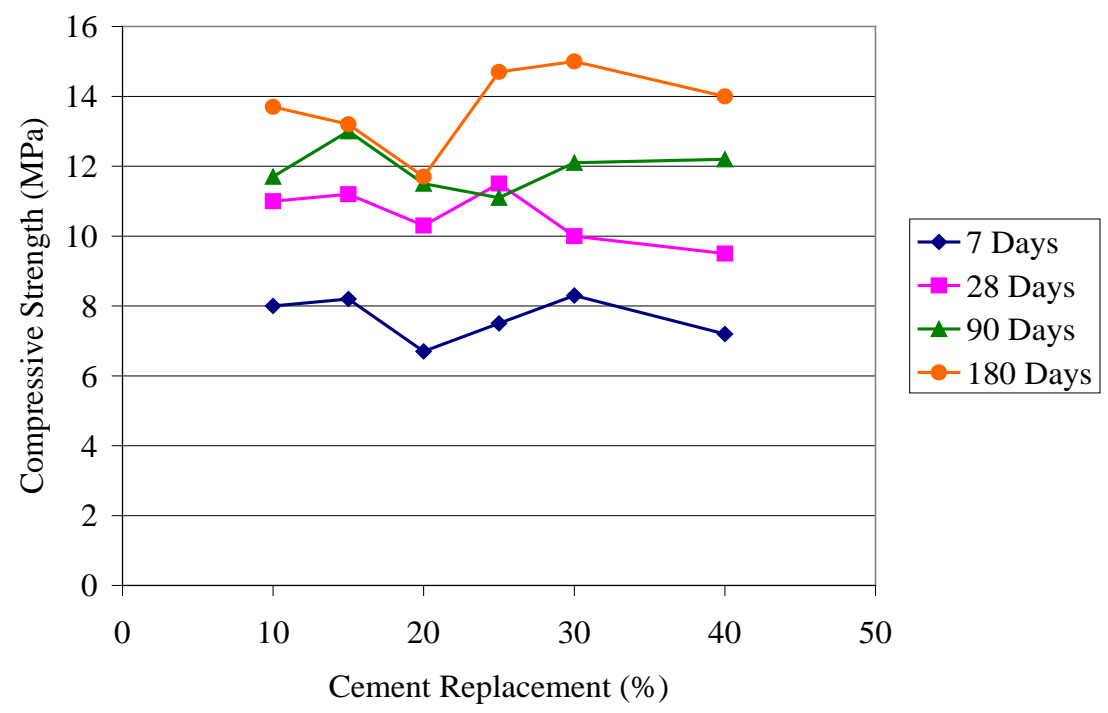

Figure 76. Graph of compressive strength of test specimens with Pozzolan J.

Table 24. Compressive strength of test specimens with Pozzolan S1.

\begin{tabular}{|l|l|l|l|l|}
\hline \multirow{2}{*}{$\begin{array}{l}\text { Portland cement } \\
\text { replacement \% }\end{array}$} & \multicolumn{4}{|l|}{ Compressive strength (MPa) } \\
\cline { 2 - 5 } & 7 Days & 28 Days & 90 Days & 180 Days \\
\hline 10 & 8.6 & 10.8 & 13.8 & 13.5 \\
\hline 15 & 4.9 & 8.05 & 12.05 & 12.8 \\
\hline 20 & 7.5 & 11.01 & 12.03 & 13.6 \\
\hline 25 & 6.8 & 7.05 & 10.9 & 11.9 \\
\hline 30 & 6.8 & 9.7 & 11.9 & 12.9 \\
\hline 40 & 5.9 & 8.05 & 10.3 & 12.3 \\
\hline
\end{tabular}

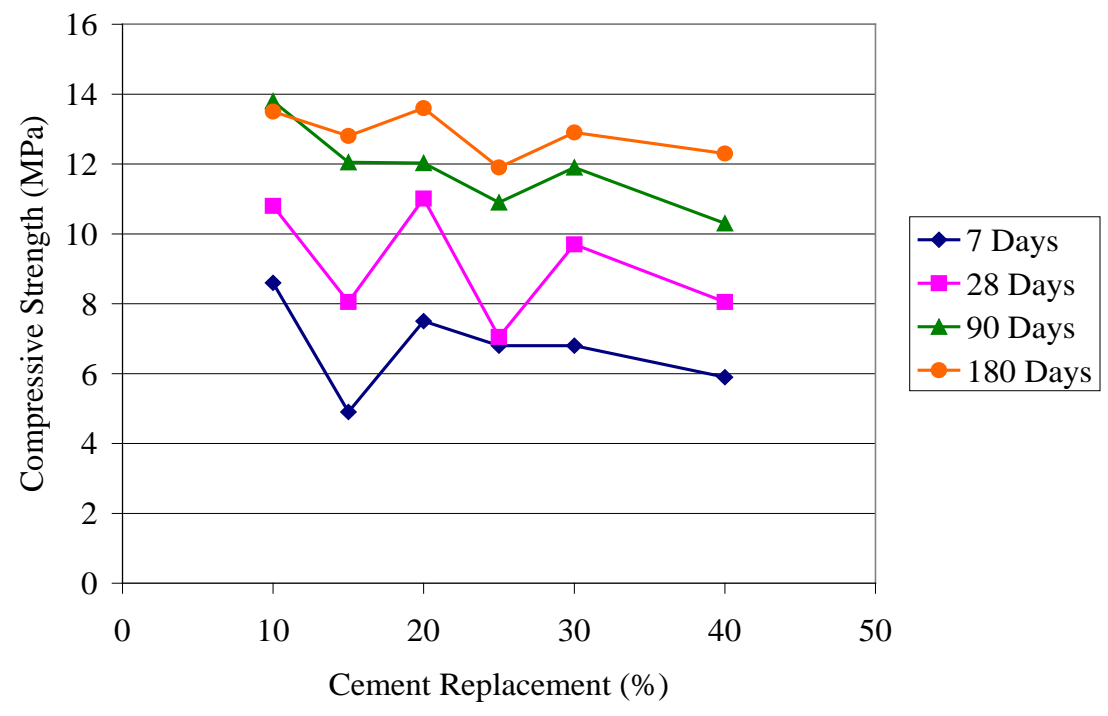

Figure 77. Graph of compressive strength of specimens with Pozzolan S1. 
Table 25. Compressive strength of specimens with Pozzolan S2.

\begin{tabular}{|l|l|l|l|l|}
\hline \multirow{2}{*}{$\begin{array}{l}\text { Portland cement } \\
\text { replacement \% }\end{array}$} & \multicolumn{4}{|l|}{ Compressive strength (MPa) } \\
\cline { 2 - 5 } & 7 Days & 28 Days & 90 Days & 180 Days \\
\hline 10 & 9.7 & 13.8 & 17.6 & 20.8 \\
\hline 15 & 8.5 & 11.2 & 17.9 & 19.1 \\
\hline 20 & 6.9 & 11.5 & 16.3 & 16.8 \\
\hline 25 & 7.7 & 10.9 & 12.2 & 16.9 \\
\hline 30 & 7.8 & 12.3 & 15 & 15.2 \\
\hline 40 & 6.2 & 7.5 & 12.9 & 14.2 \\
\hline
\end{tabular}

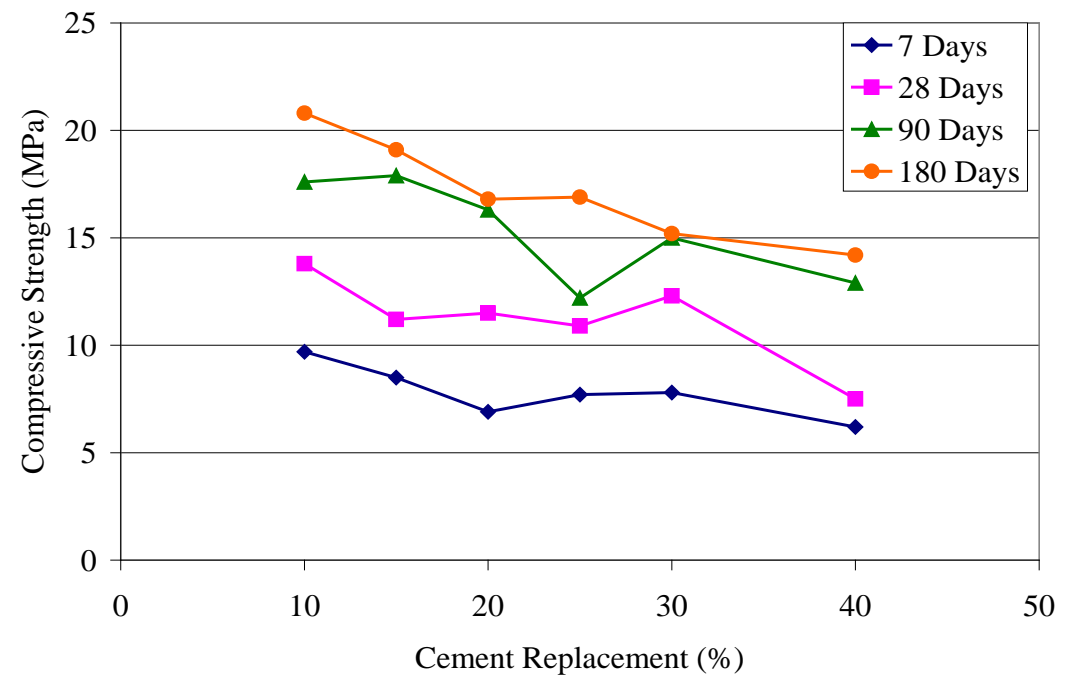

Figure 78. Graph of compressive strength of specimens with Pozzolan S2.

Table 26. Compressive strength of all test specimens after 7 days.

\begin{tabular}{|l|l|l|l|l|}
\hline \multirow{2}{*}{$\begin{array}{l}\text { Portland cement } \\
\text { replacement \% }\end{array}$} & Fly Ash & Pozzolan J & Pozzolan S1 & Pozzolan S2 \\
\cline { 2 - 5 } & 4.1 & 8 & 8.6 & 9.7 \\
\hline 10 & 6.1 & 8.2 & 4.9 & 8.5 \\
\hline 15 & 7.9 & 6.7 & 7.5 & 6.9 \\
\hline 20 & 6.9 & 7.5 & 6.8 & 7.7 \\
\hline 25 & 6.15 & 8.3 & 6.8 & 7.8 \\
\hline 30 & 7.3 & 7.2 & 5.9 & 6.2 \\
\hline 40 & & & & \\
\hline
\end{tabular}




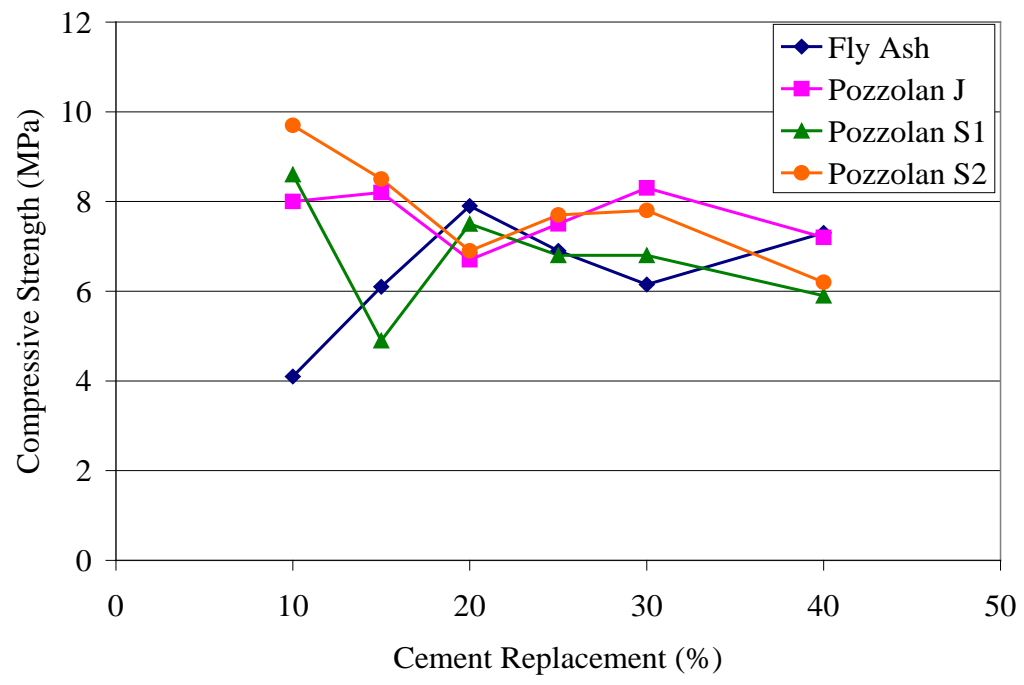

Figure 79. Graph of compressive strength of all test specimens after 7 days.

Table 27. Compressive strength of all test specimens after 28 days.

\begin{tabular}{|l|l|l|l|l|}
\hline \multirow{2}{*}{$\begin{array}{l}\text { Portland cement } \\
\text { replacement \% }\end{array}$} & \multicolumn{4}{|l|}{ Compressive strength (MPa) } \\
\cline { 2 - 5 } & Fly Ash & Pozzolan J & Pozzolan S1 & Pozzolan S2 \\
\hline 10 & 7.1 & 11 & 10.8 & 13.8 \\
\hline 15 & 10.1 & 11.2 & 8.05 & 11.2 \\
\hline 20 & 9.9 & 10.3 & 11.01 & 11.5 \\
\hline 25 & 10.1 & 11.5 & 7.05 & 10.9 \\
\hline 30 & 10.8 & 10 & 9.7 & 12.3 \\
\hline 40 & 9.5 & 9.5 & 8.05 & 7.5 \\
\hline
\end{tabular}

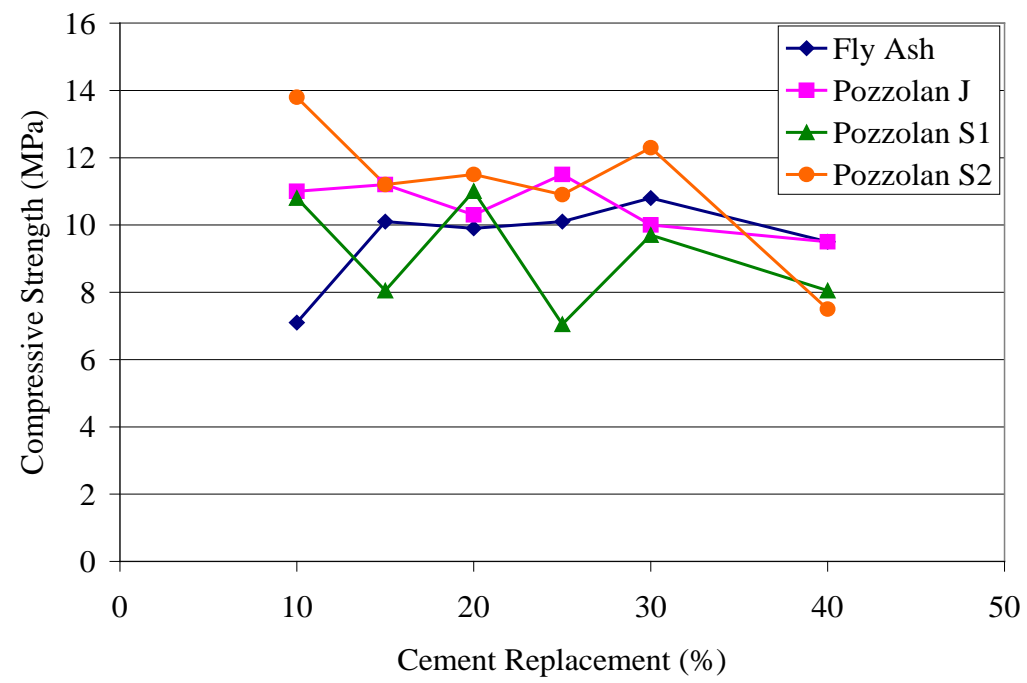

Figure 80. Graph of compressive strength of all test specimens after 28 days. 
Table 28. Compressive strength of all test specimens after 90 days.

\begin{tabular}{|l|l|l|l|l|}
\hline \multirow{2}{*}{$\begin{array}{l}\text { Portland cement } \\
\text { replacement \% }\end{array}$} & \multicolumn{4}{|l|}{ Compressive strength (MPa) } \\
\cline { 2 - 5 } & Fly Ash & Pozzolan J & Pozzolan S1 & Pozzolan S2 \\
\hline 10 & 7.2 & 11.7 & 13.8 & 17.6 \\
\hline 15 & 10.2 & 13 & 12.05 & 17.9 \\
\hline 20 & 15.2 & 11.5 & 12.03 & 16.3 \\
\hline 25 & 13 & 11.1 & 10.9 & 12.2 \\
\hline 30 & 15.8 & 12.1 & 11.9 & 15 \\
\hline 40 & 11.8 & 12.2 & 10.3 & 12.9 \\
\hline
\end{tabular}

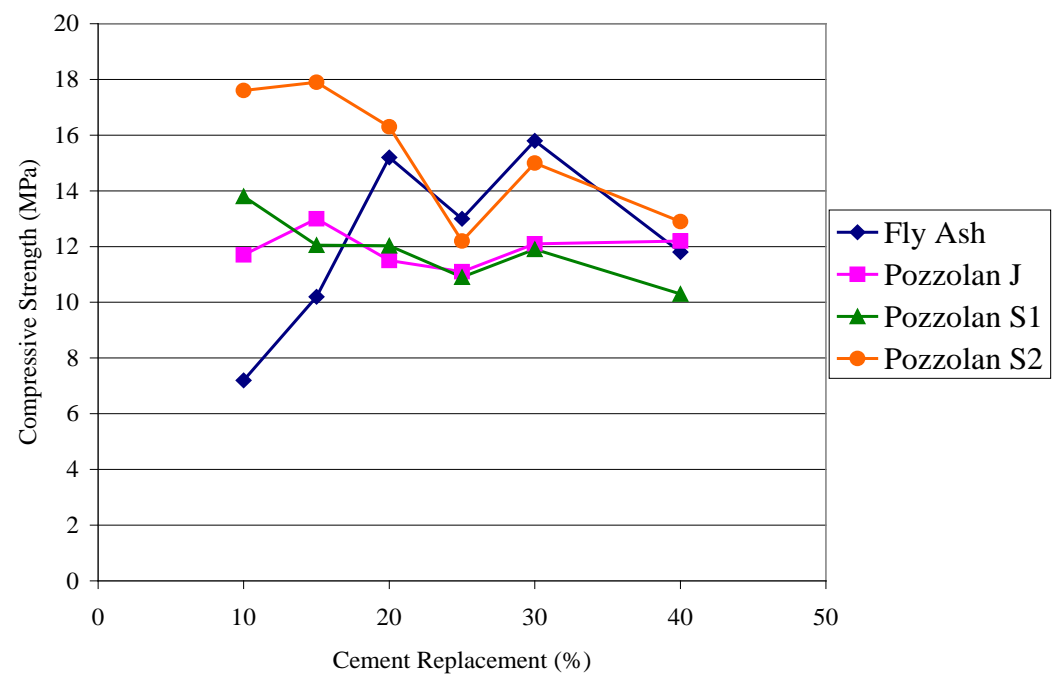

Figure 81. Graph of compressive strength of all test specimens after 90 days.

Table 29. Compressive strength after 180 days.

\begin{tabular}{|l|l|l|l|l|}
\hline \multirow{2}{*}{$\begin{array}{l}\text { Portland cement } \\
\text { replacement \% }\end{array}$} & \multicolumn{4}{|l|}{ Compressive strength (MPa) } \\
\cline { 2 - 5 } & Fly Ash & Pozzolan J & Pozzolan S1 & Pozzolan S2 \\
\hline 10 & 9.1 & 13.7 & 13.5 & 20.8 \\
\hline 15 & 14.2 & 13.2 & 12.8 & 19.1 \\
\hline 20 & 15.1 & 11.7 & 13.6 & 16.8 \\
\hline 25 & 13.1 & 14.7 & 11.9 & 16.9 \\
\hline 30 & 15 & 15 & 12.9 & 15.2 \\
\hline 40 & 16.2 & 14 & 12.3 & 14.2 \\
\hline
\end{tabular}




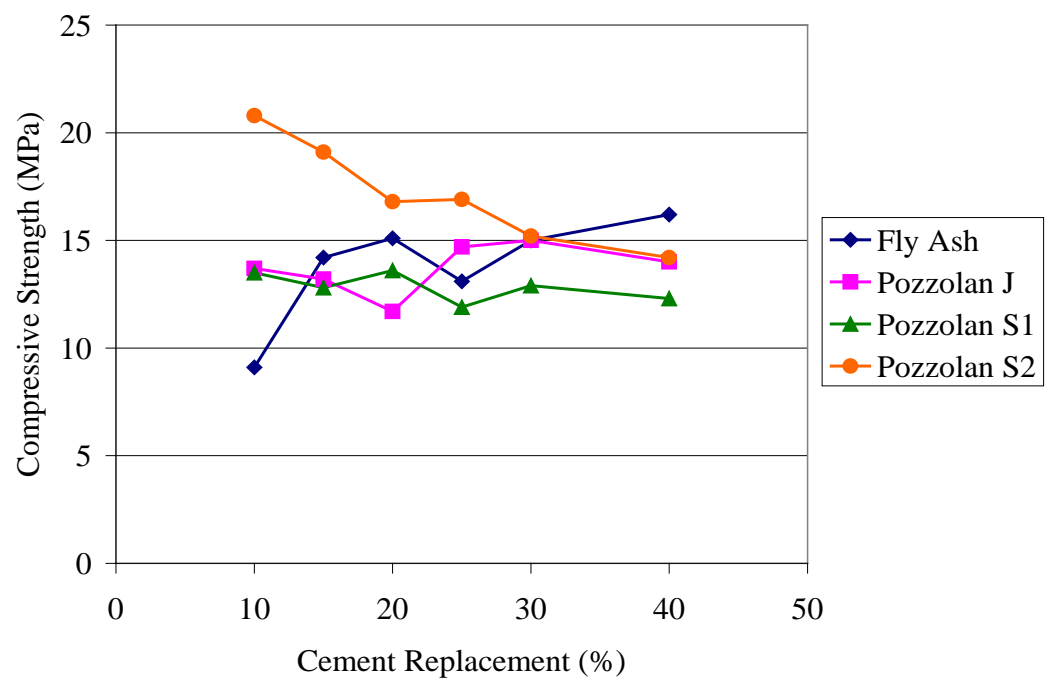

Figure 82. Compressive strength after 180 days.

\subsection{Strength activity index testing}

The purpose of this portion of the study was to analyze the strength activity index for concrete samples blended with fly ash, Pozzolan J , and Pozzolan S. Test specimens from a control mixture and a test mixture were molded in accordance with ASTM C109/C109M. In the test mixture, 20\% of the mass of Portland cement used in the control mixture was replaced by the same mass of the test pozzolan. Test cube batches were produced in accordance with ASTM C311, Standard Test Methods for Sampling and Testing Fly Ash or Natural Pozzolans for Use in Portland-Cement Concrete. The following formulas were used:

\section{- Control Mixtures}

o $500 \mathrm{~g}$ of Portland cement

- $\quad 1,375 \mathrm{~g}$ of graded standard sand (Ottawa sand, ASTM C778)

o $242 \mathrm{ml}$ of water

- Test Mixtures

o $400 \mathrm{~g}$ of Portland cement

- $100 \mathrm{~g}$ of test sample (pozzolan)

- $\quad 1,375 \mathrm{~g}$ of graded standard sand

o $242 \mathrm{ml}$ of water required for flow \pm 5 of control mixture

After molding, the specimens were placed in a moist room at $23.0 \pm 2.0^{\circ} \mathrm{C}$ for 24 hours, and then removed from the moist room and stored in saturated lime water as specified in ASTM C109/C109M, and the compressive 
strength was determined for two specimens of the control mixture and two specimens of the test mixtures at curing durations of 7 and 28 days. The pozzolanic activity index was calculated as follows:

Strength activity index with Portland cement $=$ A/B $\times 1000$

where

$A=$ average compressive strength of test mixtures cubes.

$\mathrm{B}=$ average compressive strength of control mix cubes.

The minimum ASTM C618 requirement for strength activity index is $75 \%$ at 7 and 28 days, and this specification states that "meeting the 7 days or 28 days strength activity index will indicate specifications compliance." As shown in Table 30 and Figure 84, the pozzolanic materials tested meet this requirement. For the fly ash and Pozzolan J both the activity indexes exceed the $75 \%$ requirement, as does the 28-day activity index for Pozzolan S.

Table 30. Strength activity index with different pozzaolanic materials.

\begin{tabular}{|l|l|l|}
\hline \multirow{2}{*}{ Mineral Admixture } & \multicolumn{2}{|l|}{ Activity Index, \% } \\
\cline { 2 - 3 } & $\mathbf{7}$ days & $\mathbf{2 8}$ days \\
\hline Fly Ash & 97.5 & 113.6 \\
\hline Pozzolan J & 76 & 86.8 \\
\hline Pozzolan S1 & 74.9 & 84.4 \\
\hline
\end{tabular}




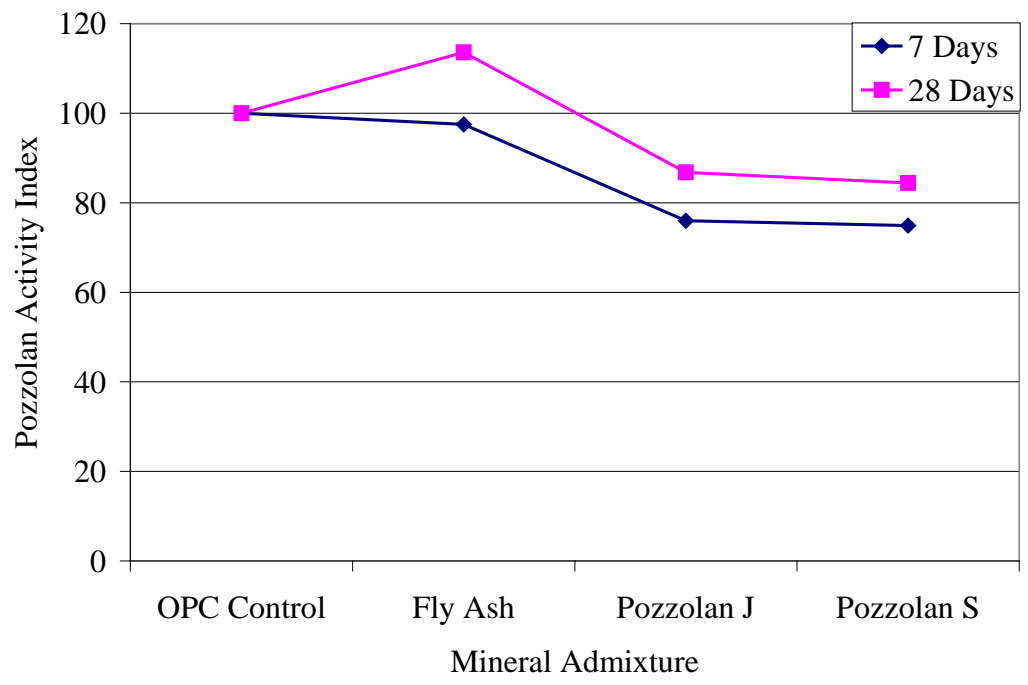

Figure 83. Graph of strength activity index for all mixtures.

\subsection{Alkali-silica reactivity testing}

The purpose of this test series was to evaluate the effectiveness of the three subject pozzolans in controlling ASR when used as a cement substitute. The investigation was carried out under laboratory conditions using procedures described in ASTM C1260, Standard Test Method for Potential Alkali Reactivity of Aggregates (Mortar-Bar Method). This method provides a means of detecting the potential of an aggregate to undergo ASR in a concrete mixture, which produces potentially harmful external expansion. The method may be especially useful for aggregates that react slowly or produce expansion late in the reaction.

Four levels of cement replacement were investigated: 10, 20, 30 and 40\%. Basalt aggregates were crushed to the proper size, as summarized in Table 31. After the aggregates were separated into the various sizes, each size was washed over a \#100 (150 $\mu \mathrm{m})$ sieve with a water spray to remove adhering dust and fine particles. The portions retained on the sieves were dried and stored in clean containers. 
Table 31. ASTM C1260 Aggregate grading requirements.

\begin{tabular}{|l|l|l|}
\hline Sieve Size Passing & Sieve Size Retained on & Mass \% \\
\hline $4.75 \mathrm{~mm}$ (No. 4) & $2.36 \mathrm{~mm}$ (No. 8) & 10 \\
\hline $2.36 \mathrm{~mm}$ (No. 8) & $1.18 \mathrm{~mm}$ (No. 16) & 25 \\
\hline $1.18 \mathrm{~mm}($ No. 16$)$ & $600 \mu \mathrm{m}($ No. 30$)$ & 25 \\
\hline $600 \mu \mathrm{m}($ No. 30$)$ & $300 \mu \mathrm{m}($ No. 50$)$ & 25 \\
\hline $300 \mu \mathrm{m}$ (No. 50) & $150 \mu \mathrm{m}($ No. 100$)$ & 15 \\
\hline
\end{tabular}

The dry materials for the test mortar were prepared using a mixture of 1 part cement to 2.25 parts of graded aggregate by mass to cast $25 \times 25 \times 286$ $\mathrm{mm}$ bars. A water-to-cement ratio equal to 0.47 by mass was used. Each mold was placed in a moist cabinet or room immediately after it was filled. The specimens remained in the molds for $24 \pm 2$ hours. Then they were removed from the molds and placed in a storage container with enough tap water to totally immerse them in an oven or water bath at $80 \pm 2.0^{\circ} \mathrm{C}$ for 24 hours.

The initial length of each test specimen was then measured using a length comparator in accordance with ASTM C490, Standard Practice for Use of Apparatus for the Determination of Length Change of Hardened Cement Paste, Mortar, and Concrete. Subsequently, test specimens were stored in a container at $80 \pm 2.0^{\circ} \mathrm{C}$ with enough $\mathrm{NaOH}$ solution for the samples to be totally immersed. Expansion data were recorded periodically, with at least three intermediate readings between the start and finish of the test.

A 14-day expansion greater than $0.20 \%$ indicates a potentially reactive aggregate in the field, while a 14 day expansion smaller than $0.10 \%$ indicates a nonreactive aggregate. Recent ASTM specifications state that 14-day expansions greater than $0.10 \%$ should be considered to indicate aggregates as reactive. Tables 32 - 35 and Figures 85 - 88 show the expansion test results. These results show that although fly ash is slightly more effective than the natural pozzolans, both pozzolans significantly reduce the 14-day expansions and control ASR. 
Table 32. Expansion of concrete with fly ash.

\begin{tabular}{|l|l|l|l|l|}
\hline \multirow{2}{*}{ Cement Replacement \% } & \multicolumn{4}{|c|}{ Expansion \% } \\
\cline { 2 - 5 } & 0 days & $\mathbf{5}$ days & 10 days & 14 days \\
\hline Control & 0 & 0.024 & 0.028 & 0.034 \\
\hline $10 \%$ & 0 & 0.014 & 0.017 & 0.0219 \\
\hline $20 \%$ & 0 & 0.012 & 0.016 & 0.0196 \\
\hline $30 \%$ & 0 & 0.009 & 0.015 & 0.0186 \\
\hline $40 \%$ & 0 & 0.008 & 0.014 & 0.0178 \\
\hline
\end{tabular}

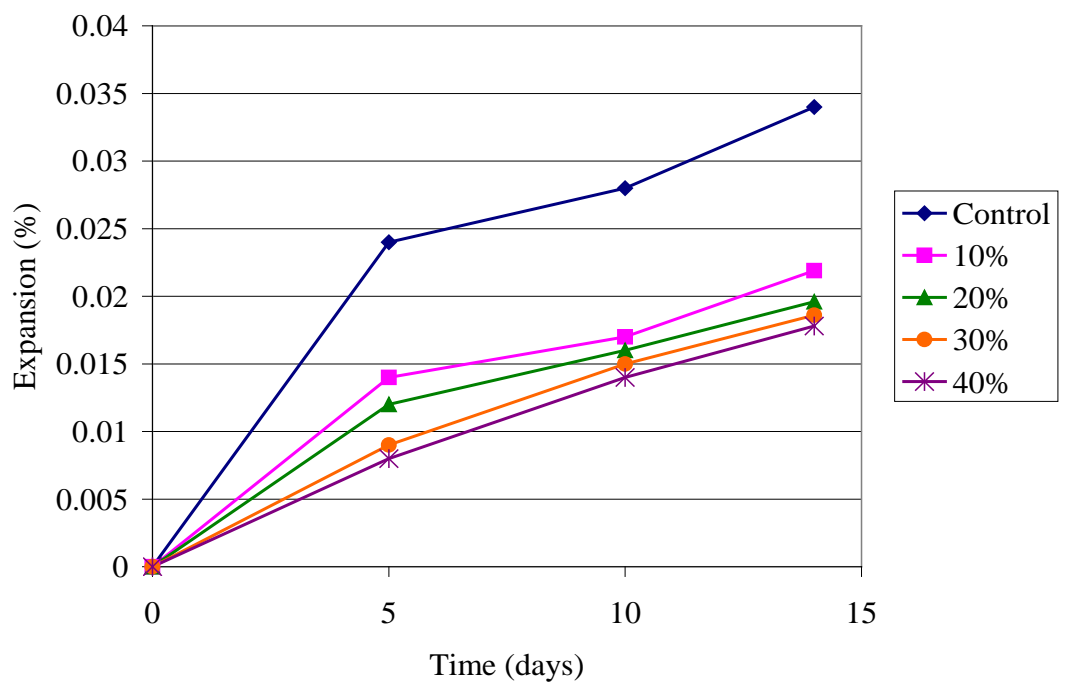

Figure 84. Graph of expansion of concrete with fly ash.

Table 33. Expansion of concrete with Pozzolan J.

\begin{tabular}{|l|l|l|l|l|}
\hline \multirow{2}{*}{ Cement Replacement, \% } & \multicolumn{4}{|l|}{ Expansion, \% } \\
\cline { 2 - 5 } & $\mathbf{0}$ days & $\mathbf{5}$ days & $\mathbf{1 0}$ days & $\mathbf{1 4}$ days \\
\hline Control & 0 & 0.023 & 0.029 & 0.033 \\
\hline $10 \%$ & 0 & 0.014 & 0.023 & 0.0261 \\
\hline $20 \%$ & 0 & 0.0125 & 0.021 & 0.0241 \\
\hline $30 \%$ & 0 & 0.012 & 0.019 & 0.0223 \\
\hline $40 \%$ & 0 & 0.011 & 0.016 & 0.0188 \\
\hline
\end{tabular}




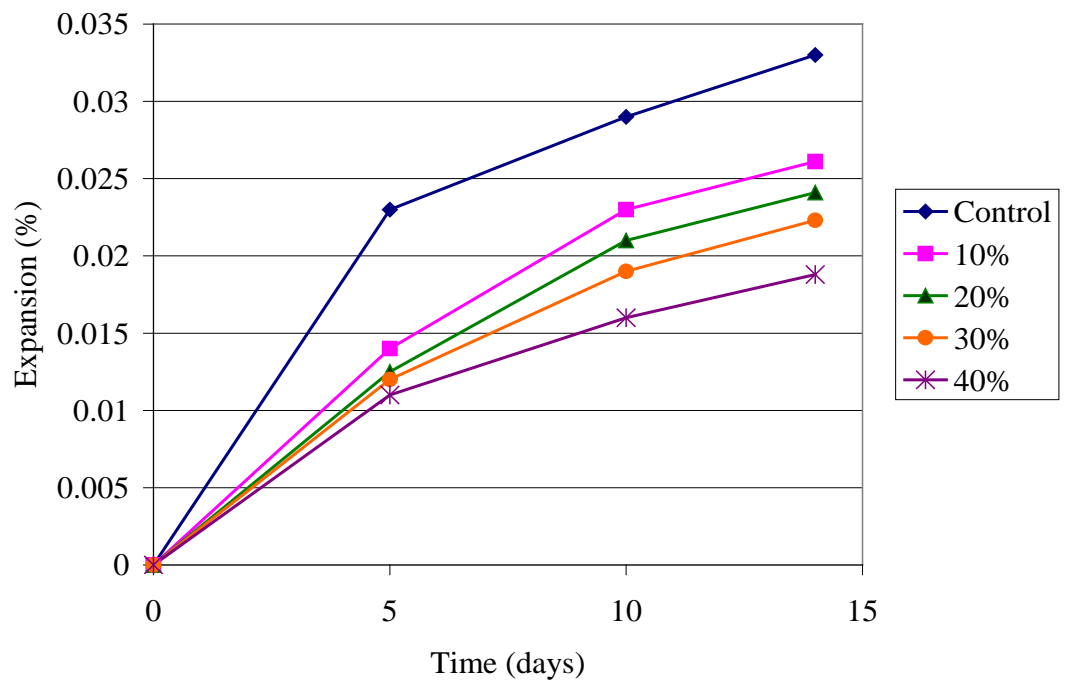

Figure 85. Graph of expansion of concrete with Pozzolan J.

Table 34. Expansion of concrete with Pozzolan S.

\begin{tabular}{|l|l|l|l|l|}
\hline \multirow{2}{*}{ Cement Replacement, \% } & \multicolumn{4}{l|}{ Expansion, \% } \\
\cline { 2 - 5 } & $\mathbf{0}$ days & $\mathbf{5}$ days & $\mathbf{1 0}$ days & $\mathbf{1 4}$ days \\
\hline Control & 0 & 0.025 & 0.029 & 0.034 \\
\hline 10 & 0 & 0.02 & 0.024 & 0.0268 \\
\hline 20 & 0 & 0.017 & 0.02 & 0.0223 \\
\hline 30 & 0 & 0.0145 & 0.0185 & 0.0221 \\
\hline 40 & 0 & 0.014 & 0.0175 & 0.0208 \\
\hline
\end{tabular}

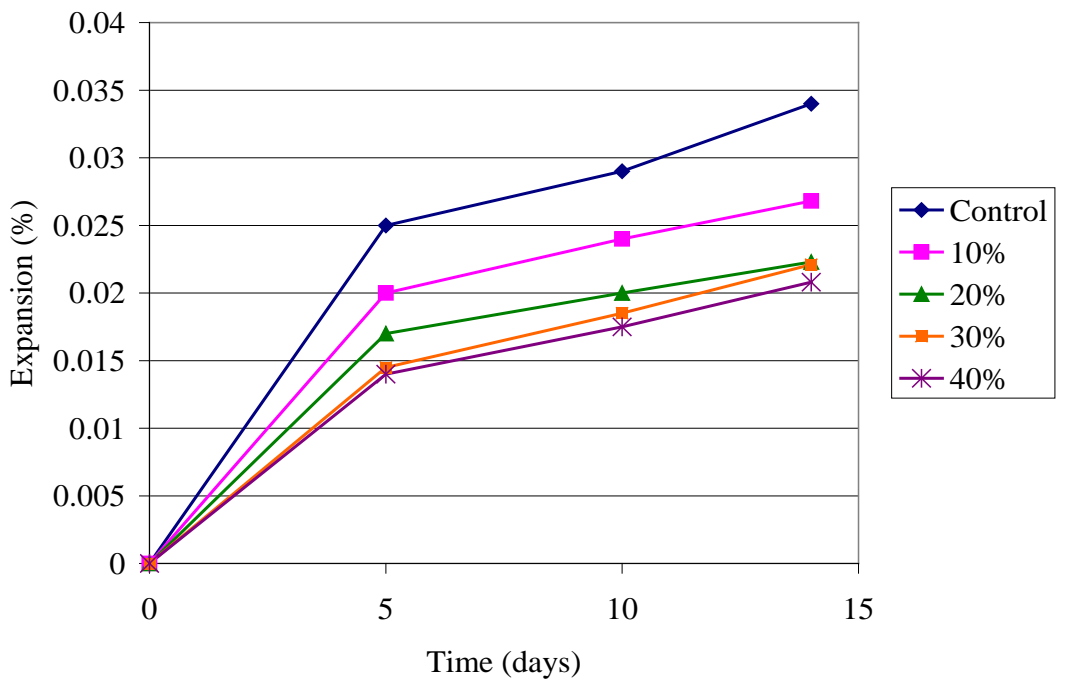

Figure 86. Graph of expansion of concrete with Pozzolan S. 
Table 35. Test specimen 14-day expansions with different admixtures.

\begin{tabular}{|c|c|c|c|c|}
\hline \multirow{2}{*}{$\begin{array}{l}\text { Mineral } \\
\text { admixture }\end{array}$} & \multicolumn{4}{|l|}{ Expansion, \% } \\
\hline & $\begin{array}{l}10 \% \text { Cement } \\
\text { replacement }\end{array}$ & $\begin{array}{l}20 \% \text { Cement } \\
\text { replacement }\end{array}$ & $\begin{array}{l}30 \% \text { Cement } \\
\text { replacement }\end{array}$ & $\begin{array}{l}40 \% \text { Cement } \\
\text { replacement }\end{array}$ \\
\hline Fly ash & 0.0219 & 0.0196 & 0.0186 & 0.0178 \\
\hline Pozzolan J & 0.0261 & 0.0241 & 0.0223 & 0.0188 \\
\hline Pozzolan S & 0.0268 & 0.0223 & 0.0221 & 0.0208 \\
\hline
\end{tabular}

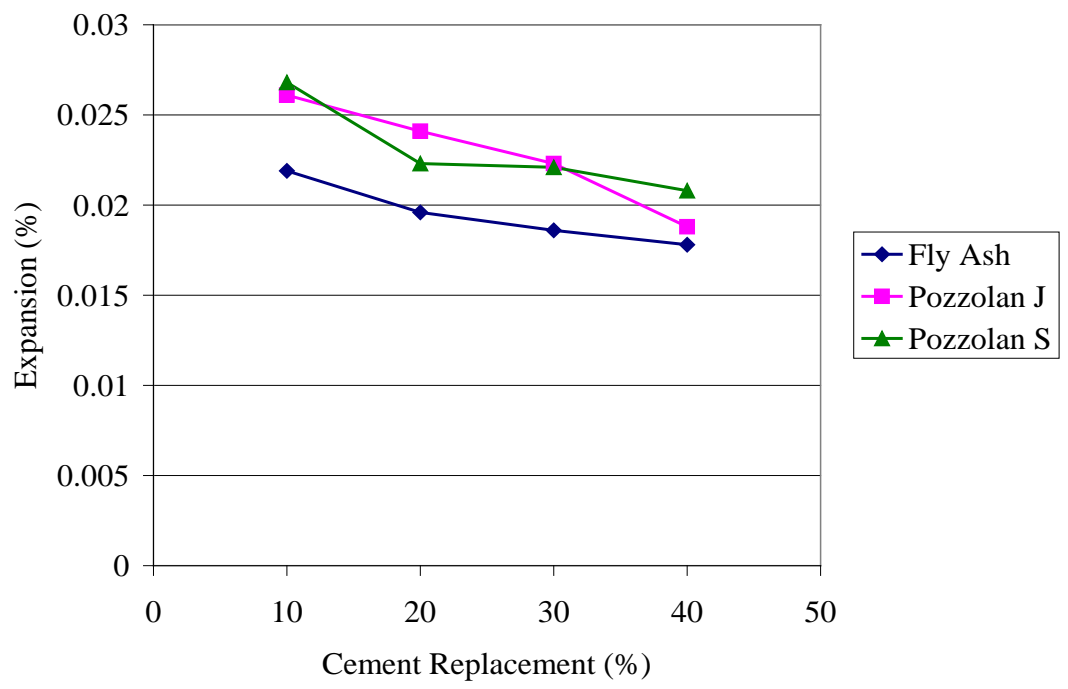

Figure 87. Graph of test specimen 14-day expansions with different admixtures.

\subsection{Heat of hydration testing}

The heat of hydration is the quantity of heat (in joules per gram of unhydrated cement) that develops upon complete hydration at a given temperature. The most common method of determining the heat of hydration is described in ASTM C186-78, Standard Test Method for Heat of Hydration of Hydraulic Cement. It is accomplished by measuring the heat of solutions of unhydrated and hydrated cement in a mixture of nitric and hydrofluoric acids. The difference between the two values represents the heat of hydration. This method was used to calculate the heat of hydration for one Portland cement control mixture and test mixtures incorporating fly ash and Pozzolan S. The results at curing durations of 1, 3, 7, 14, and 28 days are shown in Table 36 and Figure 89. This test series determined that the mixture containing Pozzolan S produced about 15\% less heat of hydration than the mixture containing fly ash, whereas the fly ash mixture produced about 30\% less heat of hydration than the control mixture using only Portland cement. 
Table 36. Heat of hydration for cement and two pozzolan mixtures.

\begin{tabular}{|l|l|l|l|l|l|}
\hline \multirow{2}{*}{ Mixture Design } & \multicolumn{5}{l|}{ Heat of hydration $(\mathrm{J} / \mathbf{g})$} \\
\cline { 2 - 7 } & $\mathbf{1}$ day & $\mathbf{3}$ days & $\mathbf{7}$ days & $\mathbf{1 4}$ days & $\mathbf{2 8}$ days \\
\hline $100 \%$ Cement & 200 & 260 & 320 & 350 & 400 \\
\hline $42.5 \%$ Cement, 57.5\% Fly Ash & 70 & 135 & 220 & 270 & 280 \\
\hline $42.5 \%$ Cement, 57.5\% Pozzolan S & 60 & 120 & 180 & 215 & 240 \\
\hline
\end{tabular}

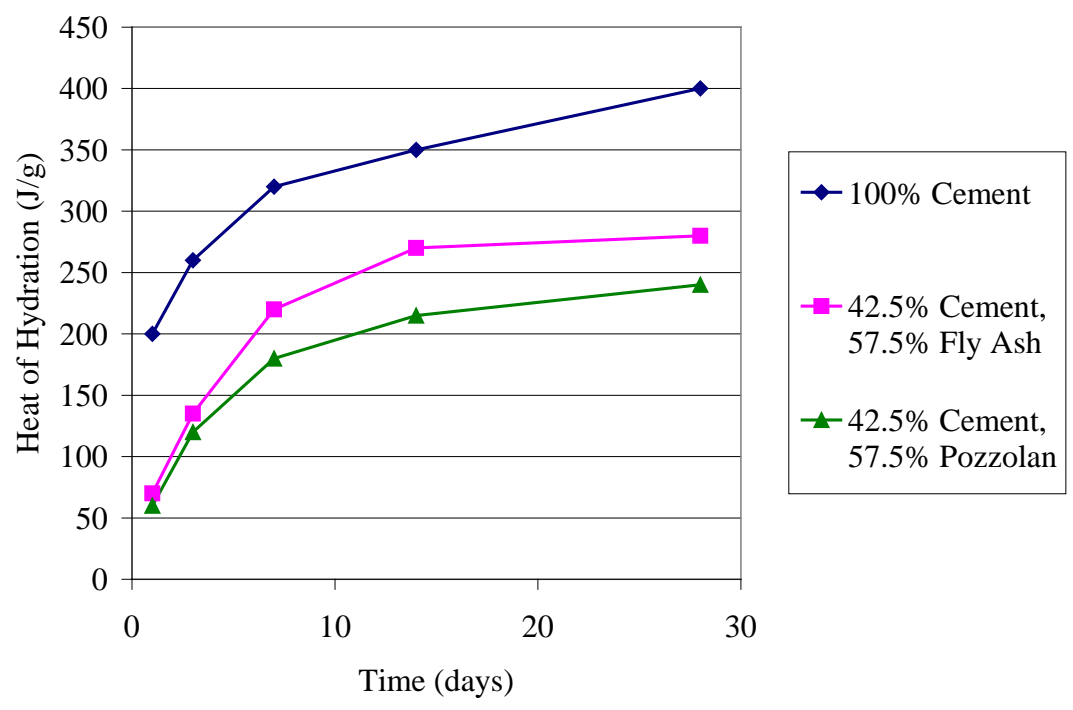

Figure 88. Graph of heat of hydration for cement and two pozzolan materials.

\subsection{Effect of pozzolan and water-to-cement ratio on slump}

Ten specimens were created with varying amounts of Pozzolan $\mathrm{SH}$ (between 0 and 30\%), and water-to-cement (W/C) ratios varying between 0.456 and 0.5 . The slump of these specimens at 0 minutes, 30 minutes, and 45 minutes is shown in Table 37 and Figures 90 - 93. In Table 37, the percentage of water reduction for specimens 5- 10 was calculated as the change between that specimen's W/C ratio and the $0.50 \mathrm{~W} / \mathrm{C}$ ratio for the control specimen, expressed as a percentage. Specimen 1 was the control specimen, with no pozzolan added. In specimens 2-4, a W/ C ratio of 0.5 was used and pozzolan was added to replace between $10 \%$ and $30 \%$ of the cement. The results in Figure 90 show that increasing the amount of pozzolan increased the slump and the workability of the specimens. In specimens 5-10, the amount of pozzolan also varied between $10 \%$ and $30 \%$, but the W/ C ratios were decreased. As expected, decreasing the W/ C ratio decreased the slump of the specimens. 
Table 37. Slump of specimens with varying amounts of pozzolan.

\begin{tabular}{|l|l|l|l|l|l|l|}
\hline \multirow{2}{*}{$\begin{array}{l}\text { Specimen } \\
\text { Number }\end{array}$} & \multirow{2}{*}{ \% Pozzolan } & W/C Ratio & \% Water & \multicolumn{3}{l|}{ Slump $(\mathbf{m m})$} \\
\cline { 5 - 7 } & & & Reduction & O Min & $\mathbf{3 0}$ Min & 45 Min \\
\hline 1 & 0 & 0.50 & 0 & 130 & 90 & 80 \\
\hline 2 & 10 & 0.50 & 0 & 160 & 125 & 110 \\
\hline 3 & 20 & 0.50 & 0 & 190 & 165 & 135 \\
\hline 4 & 30 & 0.50 & 0 & 200 & 170 & 140 \\
\hline 5 & 10 & 0.485 & 3 & 130 & 105 & 95 \\
\hline 6 & 20 & 0.47 & 6 & 125 & 85 & 85 \\
\hline 7 & 30 & 0.456 & 8.8 & 130 & 105 & 80 \\
\hline 8 & 17.5 & 0.476 & 4.8 & 150 & 125 & 105 \\
\hline 9 & 22.5 & 0.462 & 7.6 & 155 & 115 & 100 \\
\hline 10 & 20 & 0.470 & 6 & 150 & 115 & 105 \\
\hline
\end{tabular}

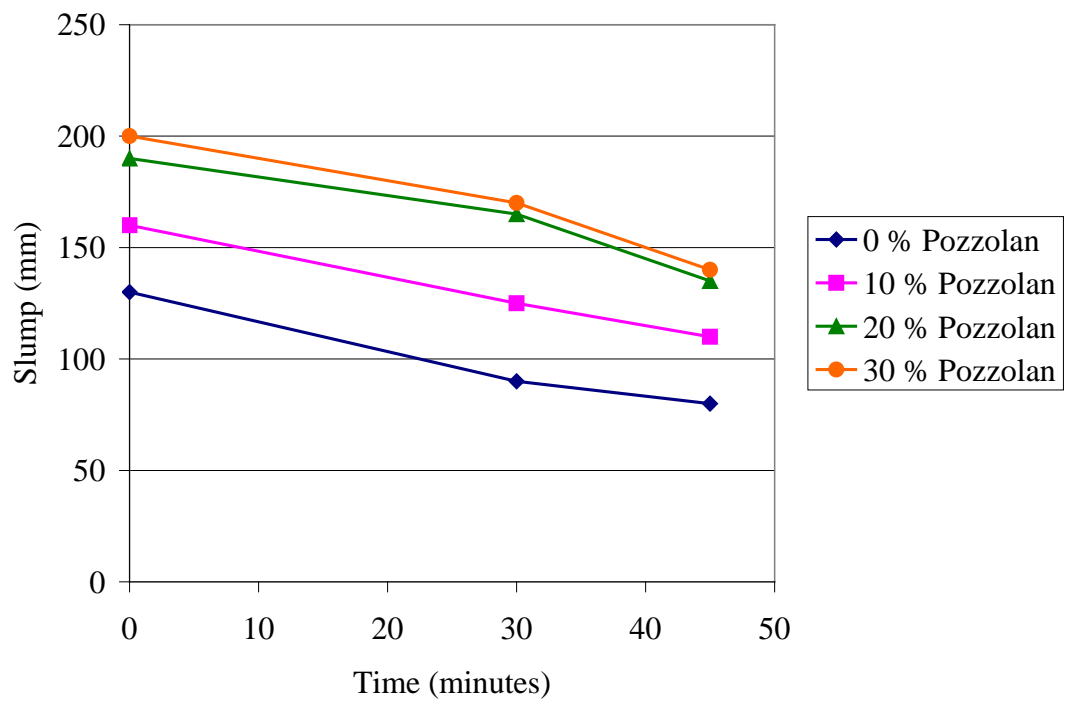

Figure 89. Slump for specimens 1-4. 


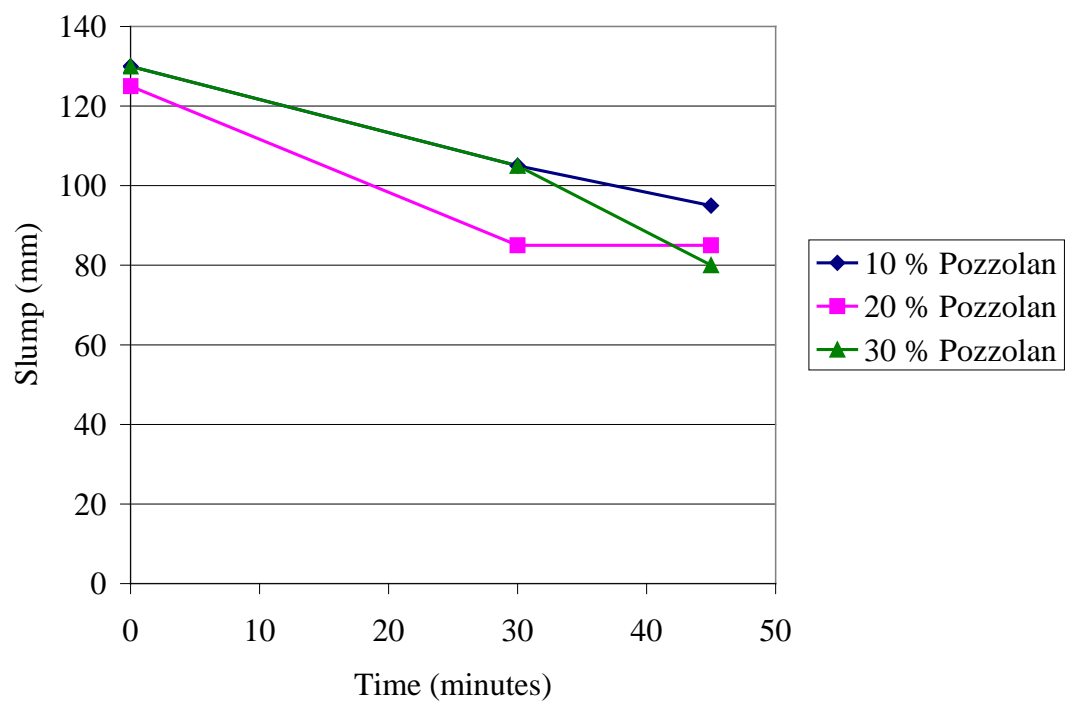

Figure 90. Slump for specimens 5-7.

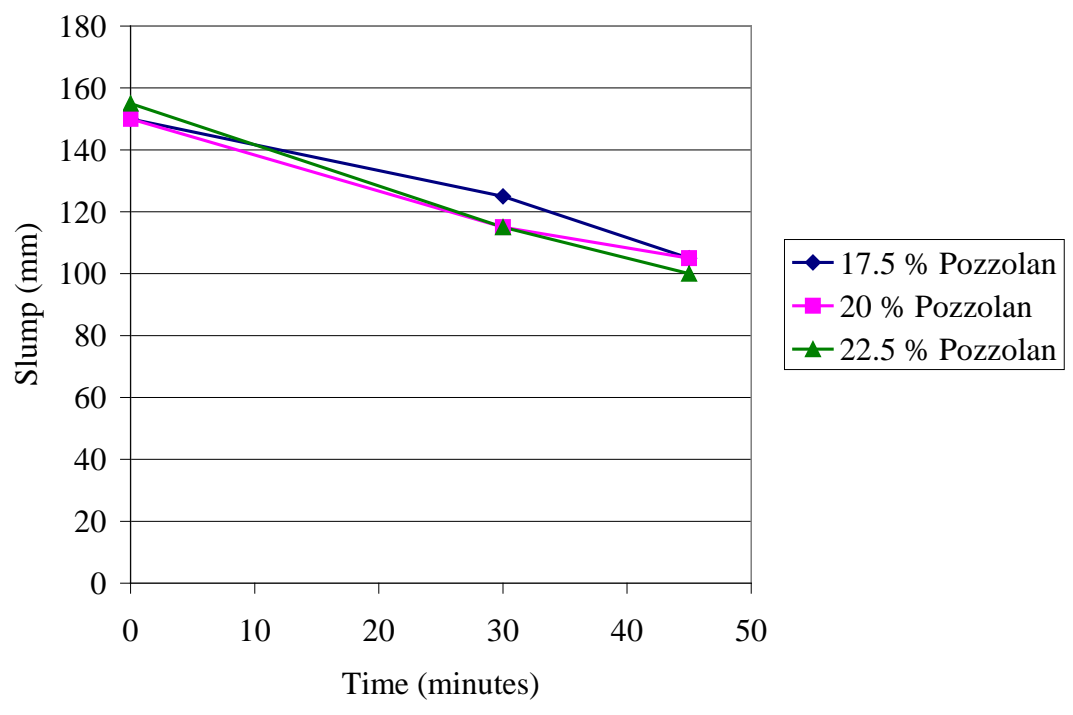

Figure 91. Slump for specimens 8-10. 


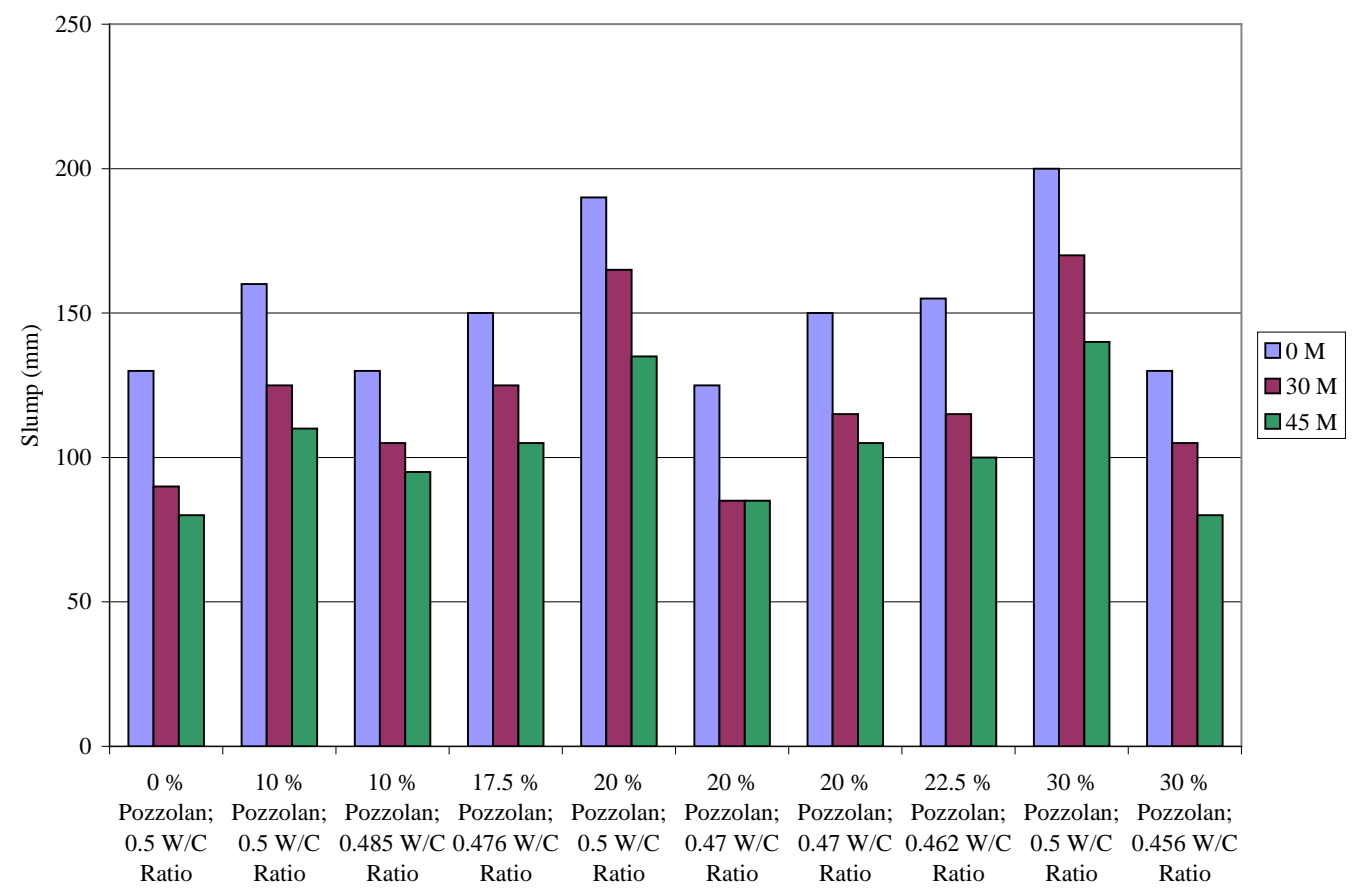

Figure 92. Bar chart of slump for all test mixtures.

\subsection{Effect of pozzolan and water-to-cement ratio on strength}

As shown in Table 38, 13 specimens with varying amounts of pozzolan $\mathrm{SH}$ and $\mathrm{W} / \mathrm{C}$ ratios were tested in compression after 7 and 28 days to determine the effect of the pozzolan and W/ C ratio on the compressive strength. The results of these tests are shown in Table 38 and Figures 94 - 107. In Table 38, the strength increase between 7 and 28 days is calculated by subtracting the 7- and 28-day compressive strengths, as measured in MPa. This number is also calculated as a percentage of increase in strength. The strength increase compared with the control sample is calculated by comparing the strength increases (in MPa) with the 7.9 MPa strength increase of the control specimen. In the last two columns, the 7- and-28 day activity indexes are calculated by dividing the specimen strength by the strength of the control specimen at 7 and 28 days, respectively, and multiplying by 100\%. The results in Figures 94 - 96 generally show that increasing the percentage of pozzolan decreases the specimen strength. Specimens 11- 13 all contained $20 \%$ pozzolan, but with different fineness values. As shown in Figure 97, the compressive strengths of these specimens increased with increasing pozzolan fineness. Figures 98 and 99 demonstrate that decreasing the W/ C ratio can increase the strength of the specimen. Finally, Figures 100 - 107 plot the strength increases and activity indexes for all the specimens. 
Table 38. Strength and activity index of specimens with varying amounts of pozzolan.

\begin{tabular}{|c|c|c|c|c|c|c|c|c|c|c|}
\hline \multirow[t]{2}{*}{$\begin{array}{l}\text { Specim } \\
\text { en \# }\end{array}$} & \multirow[t]{2}{*}{ Remarks } & \multirow[t]{2}{*}{$\begin{array}{l}\text { W/C } \\
\text { Ratio }\end{array}$} & \multicolumn{2}{|c|}{ Strength, $\mathrm{MPa}$} & \multicolumn{2}{|c|}{$\begin{array}{l}\text { Strength } \\
\text { increase } \\
\text { between } 7 \\
\text { and } 28 \text { days }\end{array}$} & \multicolumn{2}{|c|}{$\begin{array}{l}\text { Strength } \\
\text { increase } \\
\text { compared } \\
\text { with control } \\
\text { sample }\end{array}$} & \multicolumn{2}{|c|}{ Activity Index, \% } \\
\hline & & & $\begin{array}{l}7 \\
\text { Days }\end{array}$ & $\begin{array}{l}28 \\
\text { Days }\end{array}$ & $\mathrm{MPa}$ & $(\%)$ & $\mathrm{MPa}$ & (\%) & $\begin{array}{l}7 \\
\text { Days }\end{array}$ & $\begin{array}{l}28 \\
\text { Days }\end{array}$ \\
\hline 1 & 0\% Pozzolan & 0.50 & 34.5 & 42.4 & 7.9 & 22.9 & 0.0 & 0.0 & 100.0 & 100.0 \\
\hline 2 & 10\% Pozzolan & 0.50 & 31.3 & 37.6 & 6.3 & 20.1 & -1.6 & -20.3 & 90.7 & 88.7 \\
\hline 3 & 20\% Pozzolan & 0.50 & 26.4 & 31.1 & 4.7 & 17.8 & -3.2 & -40.5 & 76.5 & 73.3 \\
\hline 4 & 30\% Pozzolan & 0.50 & 21.7 & 24.3 & 2.6 & 12.0 & -5.3 & -67.1 & 62.9 & 57.3 \\
\hline 5 & 10\% Pozzolan & 0.485 & 31.8 & 40.7 & 8.9 & 28.0 & 1.0 & 12.7 & 92.2 & 96.0 \\
\hline 6 & 20\% Pozzolan & 0.47 & 32.7 & 41.4 & 8.7 & 26.6 & 0.8 & 10.1 & 94.8 & 97.6 \\
\hline 7 & 30\% Pozzolan & 0.456 & 28 & 38.4 & 10.4 & 37.1 & 2.5 & 31.6 & 81.2 & 90.6 \\
\hline 8 & 17.5\% Pozzolan & 0.476 & 32.3 & 41.6 & 9.3 & 28.8 & 1.4 & 17.7 & 93.6 & 98.1 \\
\hline 9 & 22.5\% Pozzolan & 0.462 & 29.3 & 40.1 & 10.8 & 36.9 & 2.9 & 36.7 & 84.9 & 94.6 \\
\hline 10 & 20\% Pozzolan & 0.470 & 29.4 & 42.3 & 12.9 & 43.9 & 5.0 & 63.3 & 85.2 & 99.8 \\
\hline 11 & $\begin{array}{l}\text { 20\% Pozzolan } \\
\text { (PASS.38mic) PR-150, } \\
\text { (CC:340) }\end{array}$ & 0.480 & 23.7 & 30.3 & 6.6 & 27.8 & 0.0 & 0.0 & 100.0 & 100.0 \\
\hline 12 & $\begin{array}{l}\text { 20\% Pozzolan (PASS. } \\
\text { 32mic) PR-150, (CC:340) }\end{array}$ & 0.480 & 24.1 & 36.1 & 12.0 & 49.8 & 5.4 & 81.8 & 101.7 & 119.1 \\
\hline 13 & $\begin{array}{l}\text { 20\% Pozzolan (PASS. } \\
\text { 20mic) PR-150, (CC:340) }\end{array}$ & 0.480 & 31.4 & 37.15 & 5.7 & 18.2 & -0.9 & -13.5 & 132.7 & 122.6 \\
\hline
\end{tabular}

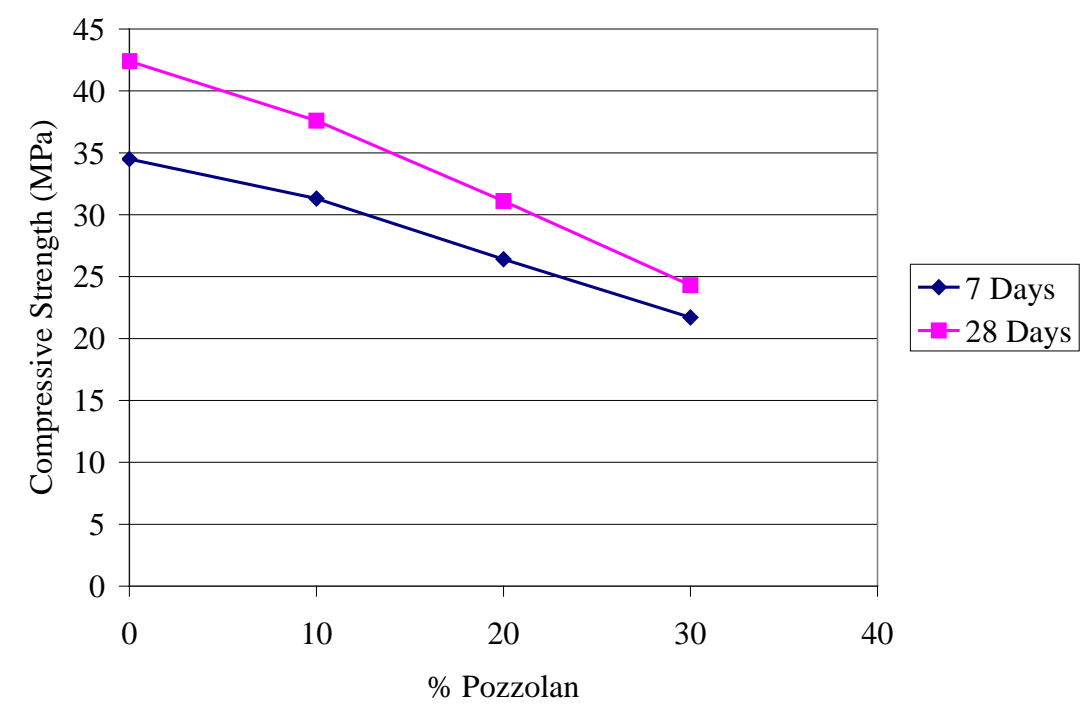

Figure 93. Compressive strength of specimens 1-4. 


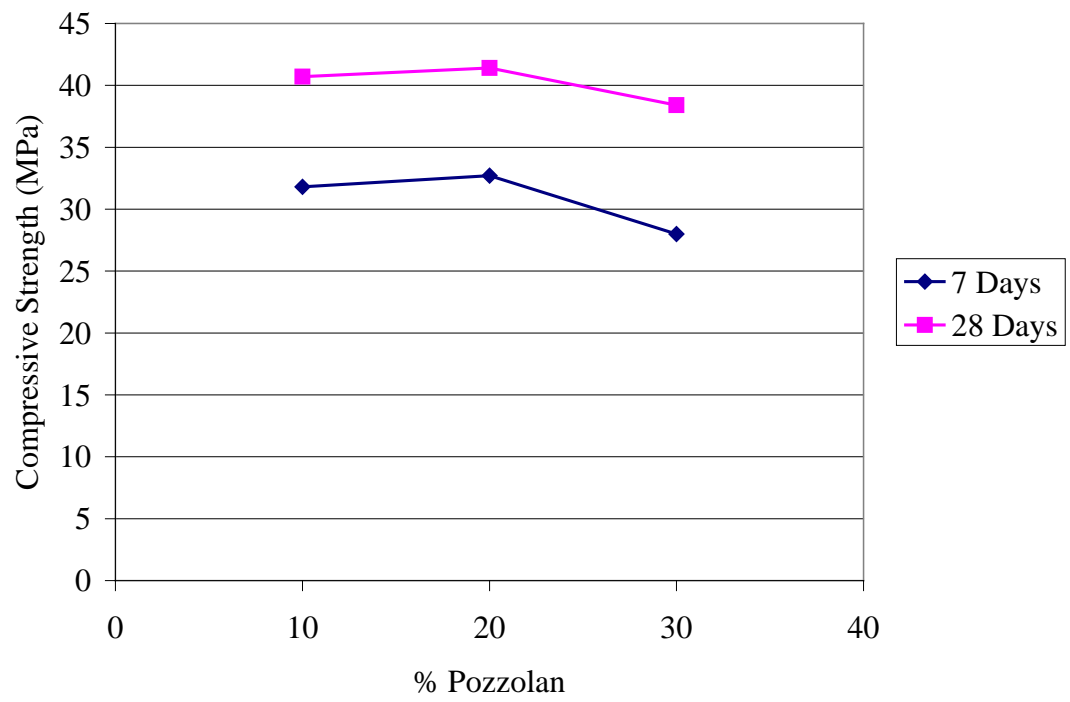

Figure 94. Compressive strength of specimens 5-7.

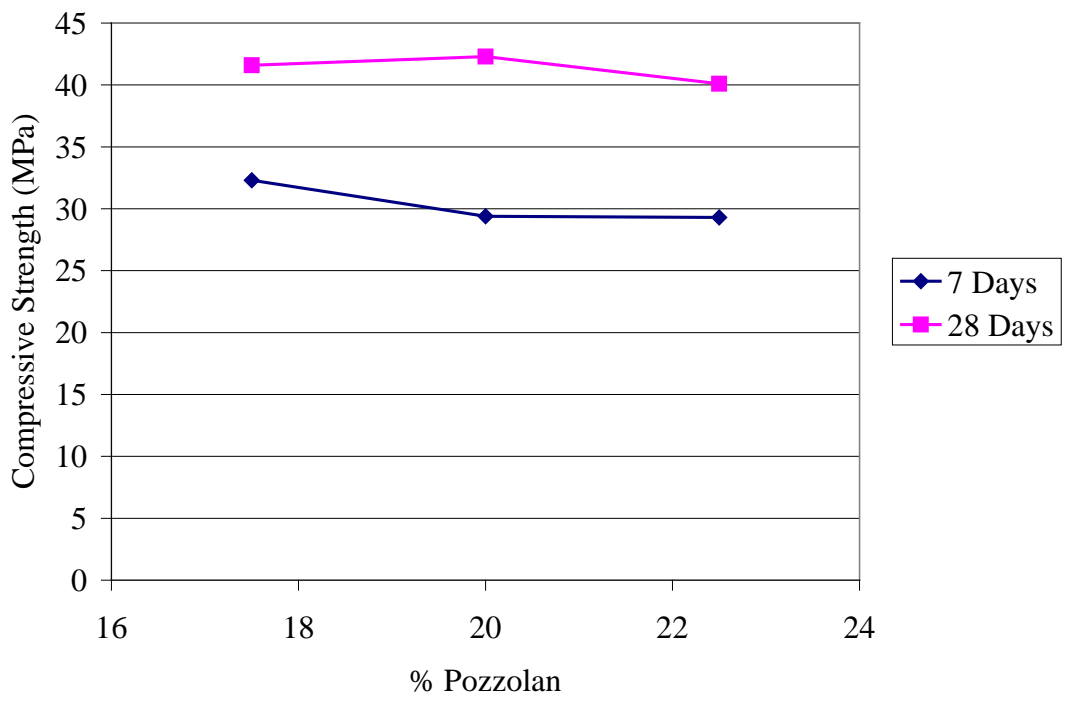

Figure 95. Compressive strength of specimens 8-10. 


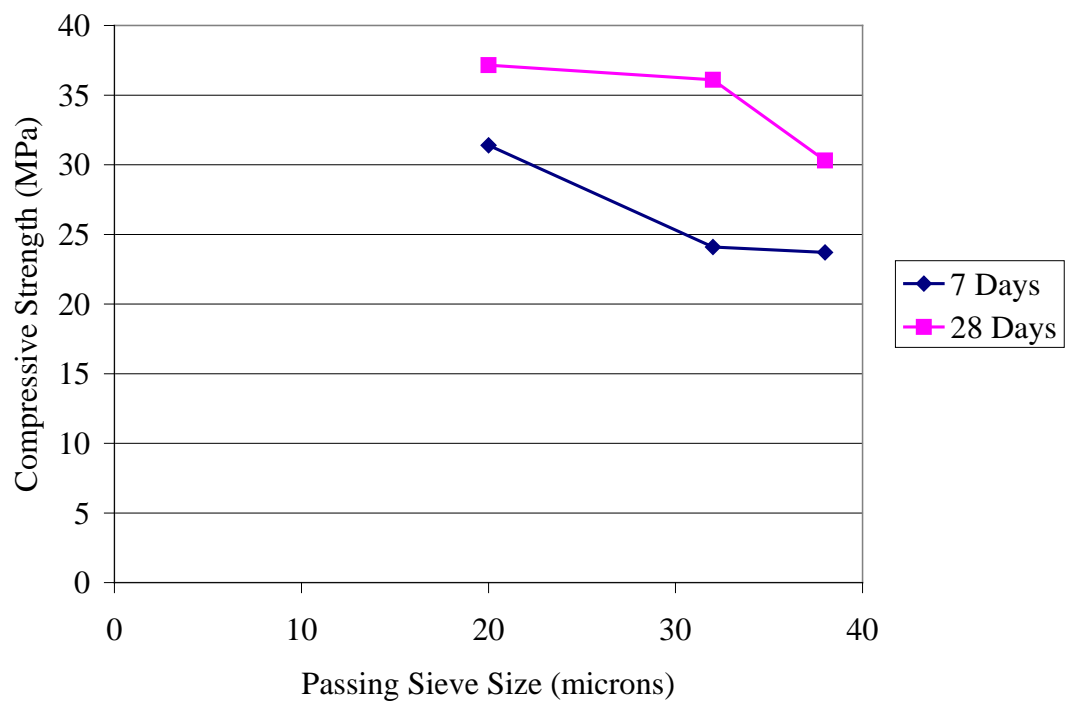

Figure 96. Compressive strength of specimens 11-13.

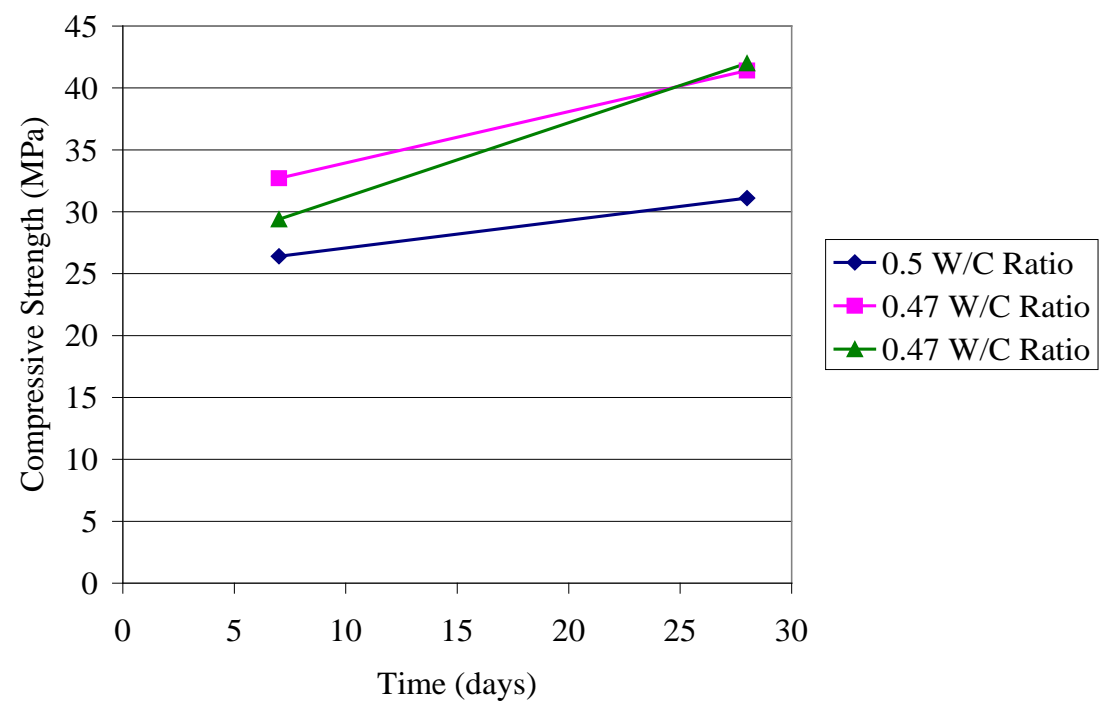

Figure 97. Relationship between W/C ratio and strength for $20 \%$ pozzolan. 


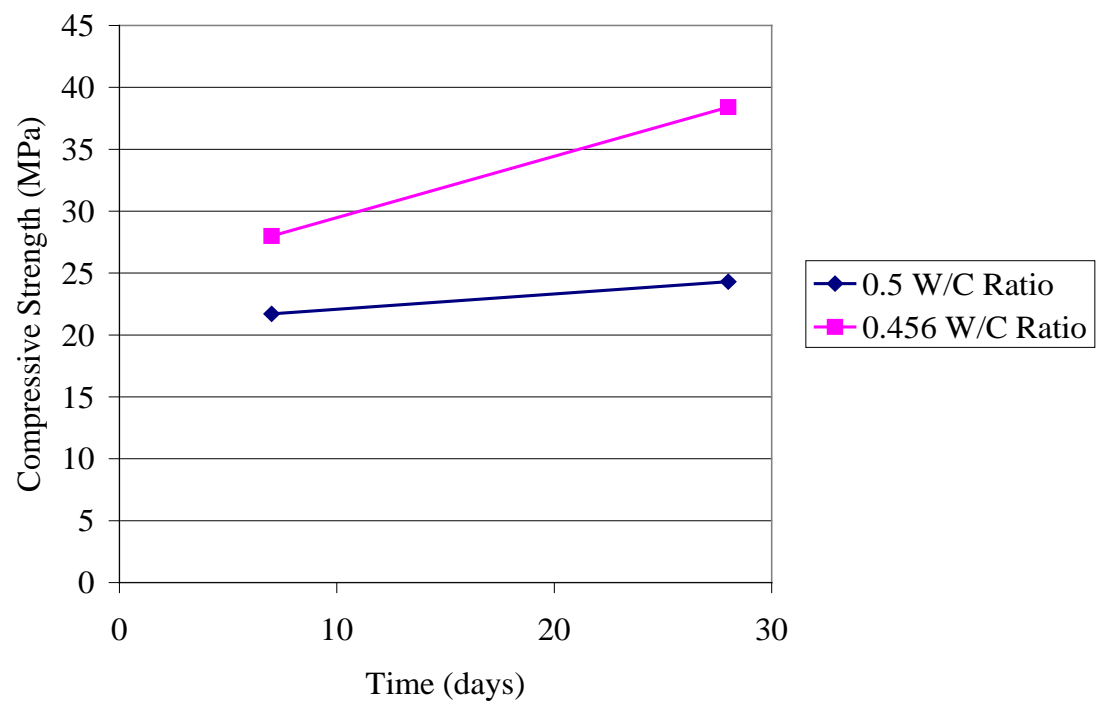

Figure 98. Relationship between W/C ratio and strength for $30 \%$ pozzolan.

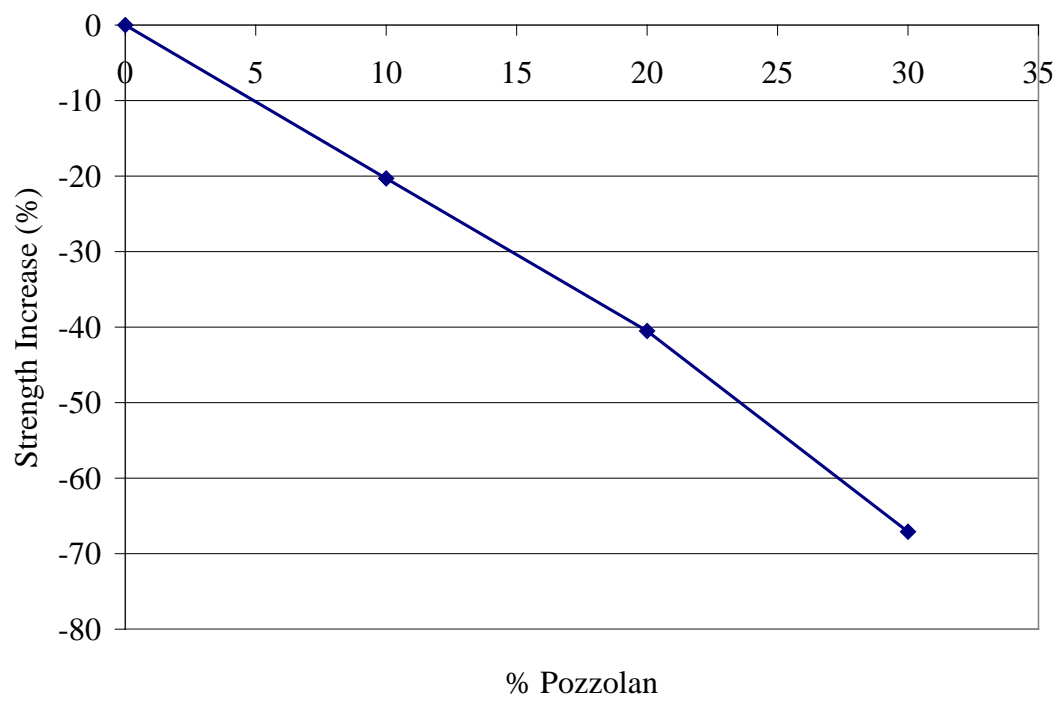

Figure 99. Strength increase for specimens 1-4. 


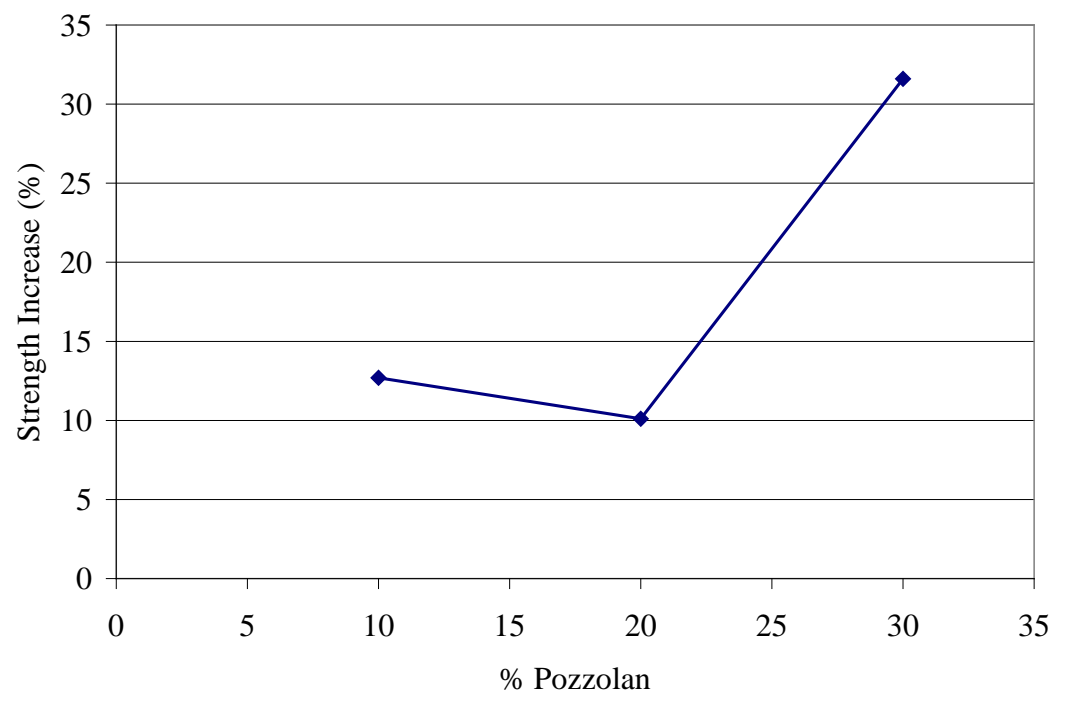

Figure 100. Strength increase for specimens 5-7.

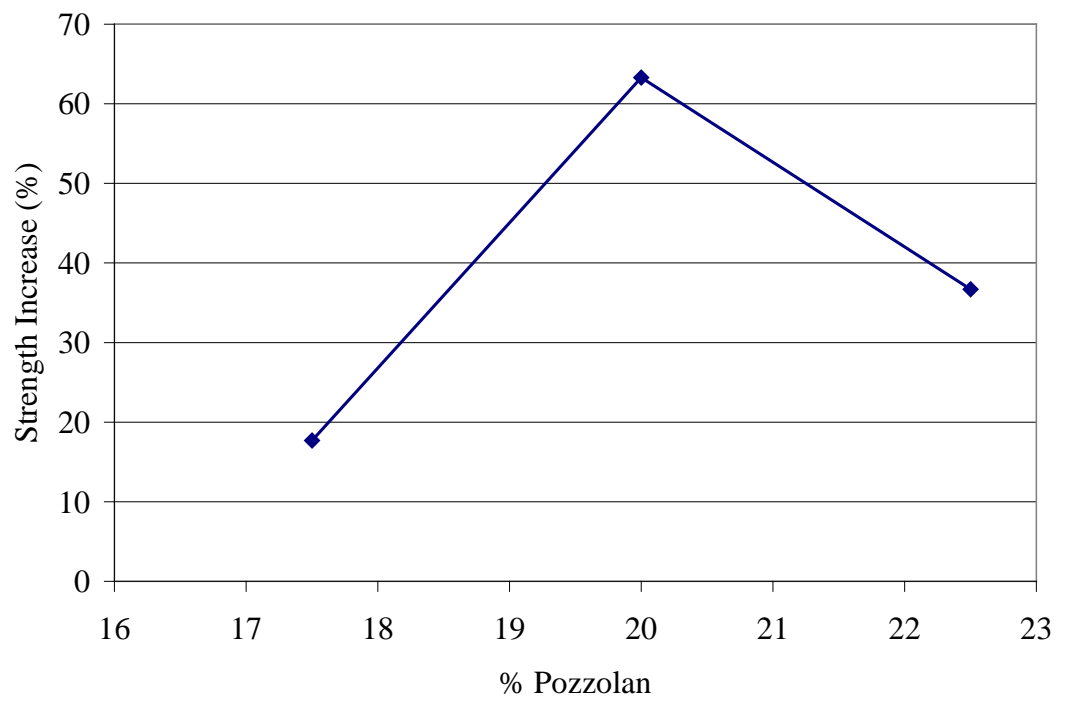

Figure 101. Strength increase for specimens 8-10. 


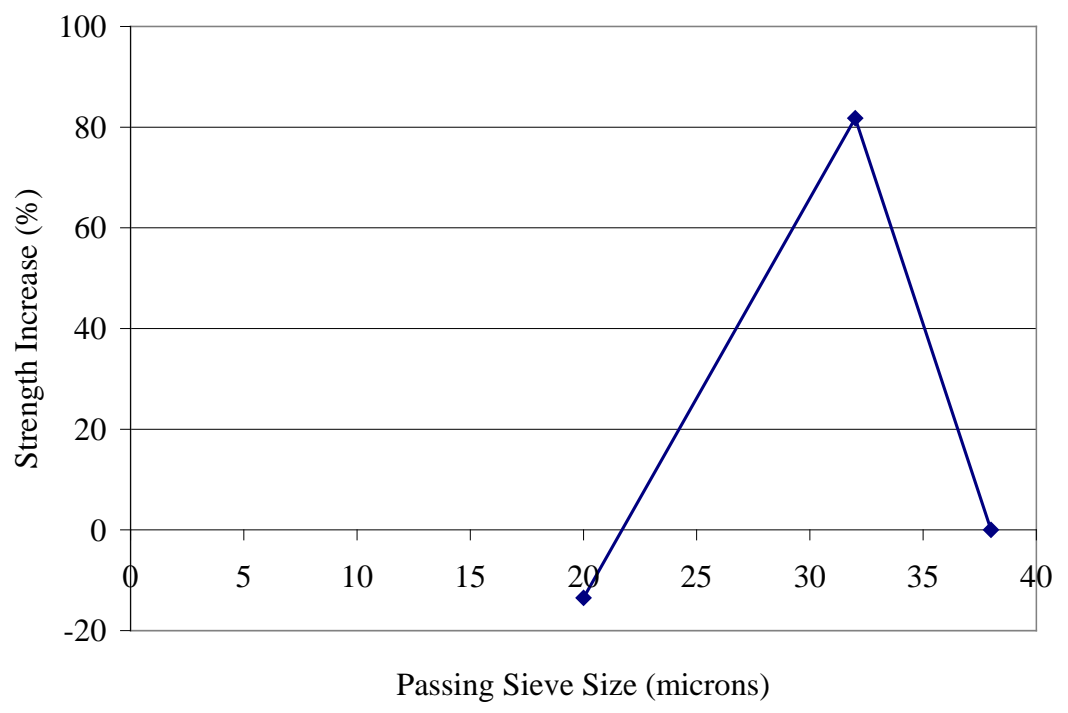

Figure 102. Strength increase for specimens 11-13.

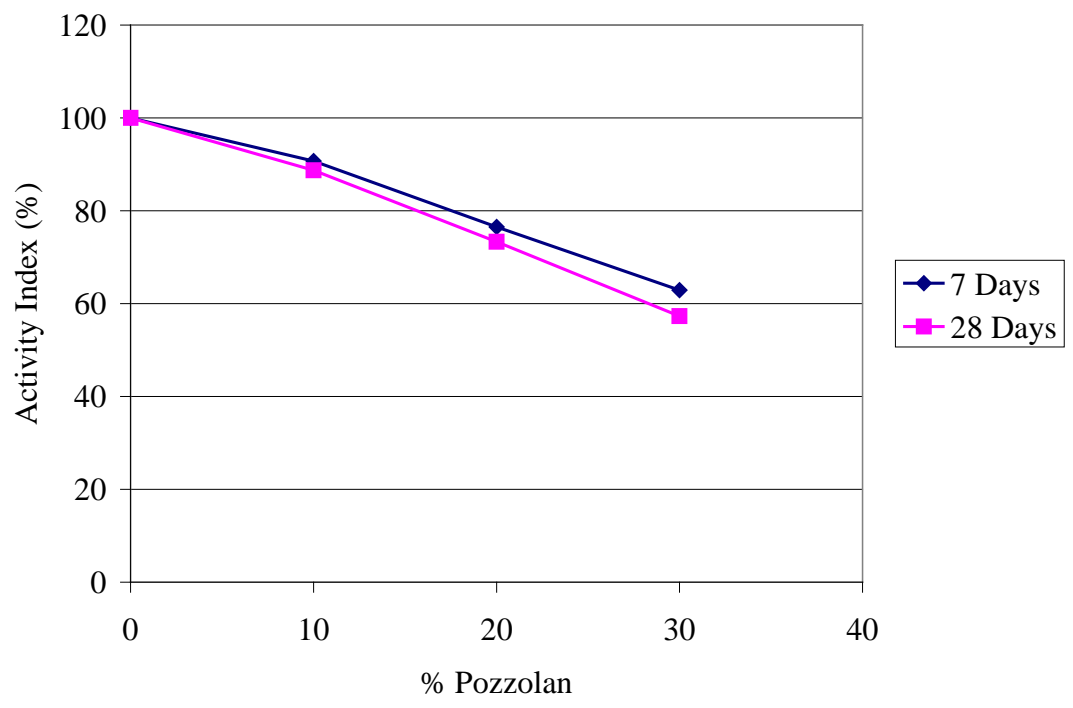

Figure 103. Activity index for specimens 1-4. 


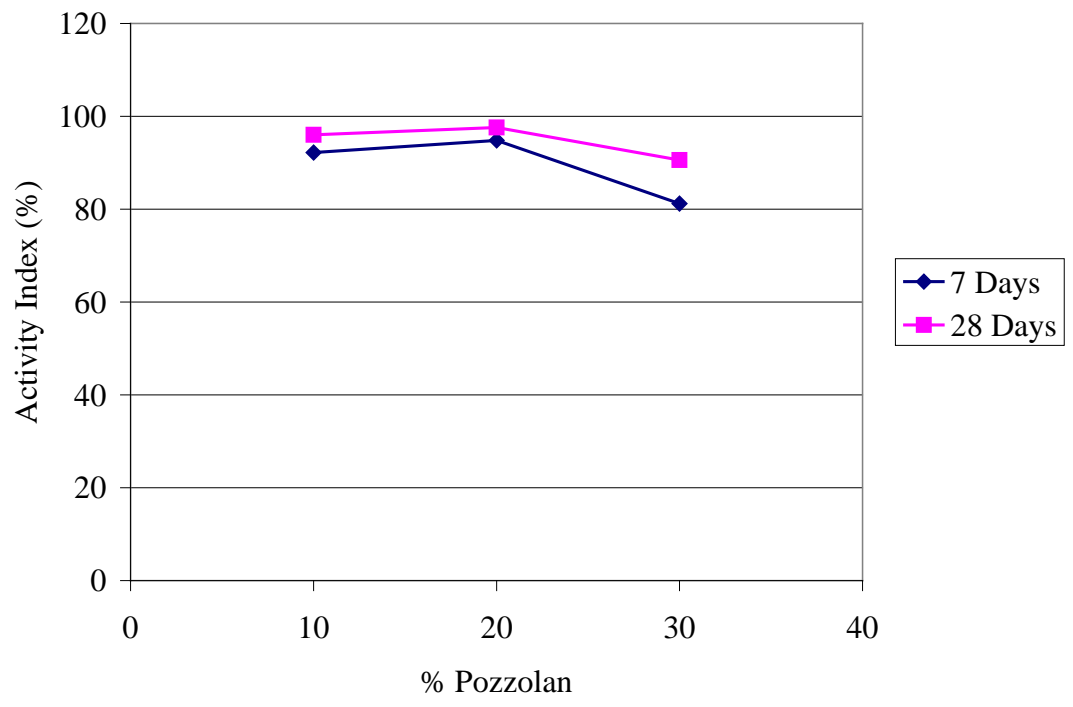

Figure 104. Activity index for specimens 5-7.

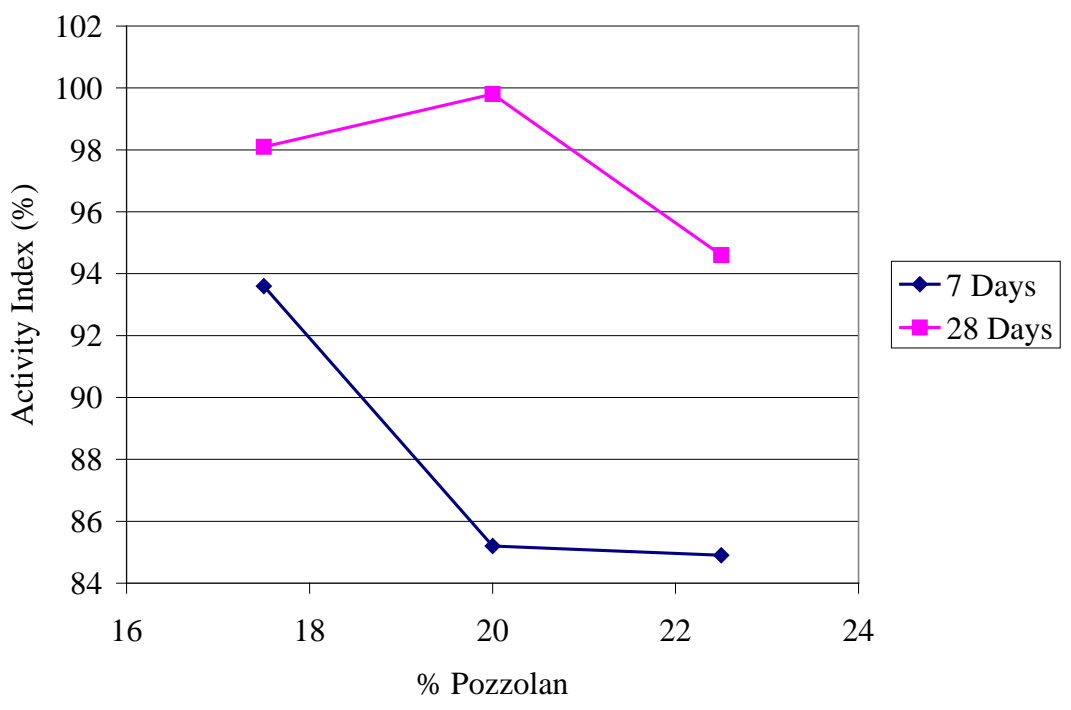

Figure 105. Activity index for specimens 8-10. 


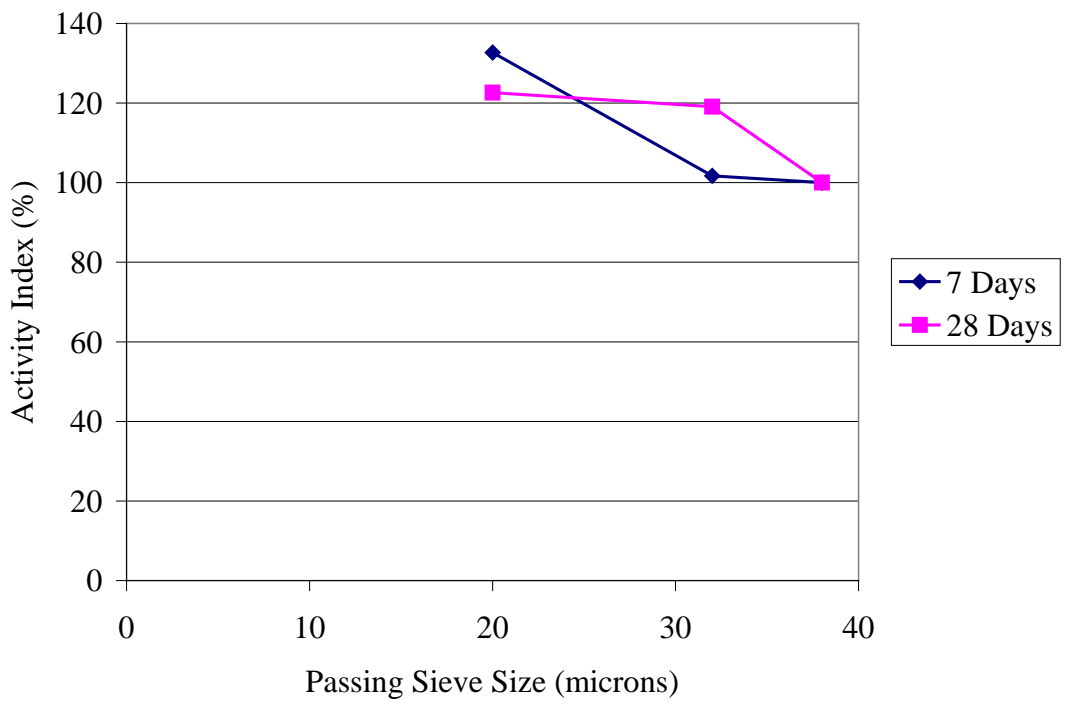

Figure 106. Activity index for specimens 11-13. 


\section{Comparison of Pozzolan with ASTM Specifications for Fly Ash and Silica Fume}

The properties of 20 micron fine natural Pozzolan S1 were investigated and compared with the ASTM specifications for fly ash and silica fume to determine the extent of their similarity. The following ASTM specifications were used as reference standards:

- ASTM C618-00, Standard Specification for Coal Fly Ash and Raw or Calcined Natural Pozzolan for Use as a Mineral Admixture in Concrete

- ASTM C1240-00, Standard Specification for use of Silica Fume as a Mineral Admixture in Hydraulic Cement Concrete Mortar and Grout.

The physical and chemical requirements of these two specifications are shown in Table 39.

Table 39. ASTM requirements for fly ash and silica fume.

\begin{tabular}{|c|c|c|c|c|c|}
\hline & \multirow{3}{*}{ Requirements } & \multicolumn{3}{|c|}{ ASTM C618 } & \multirow{3}{*}{$\begin{array}{l}\text { ASTM C1240 } \\
\text { Silica fume }\end{array}$} \\
\hline & & \multirow{2}{*}{$\begin{array}{l}\text { Natural } \\
\text { Pozzolan } \\
\text { Class N* }\end{array}$} & \multicolumn{2}{|l|}{ Fly ash } & \\
\hline & & & Class $F^{*}$ & Class C* & \\
\hline \multirow{6}{*}{ 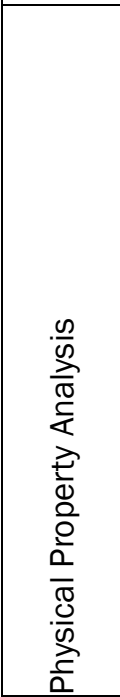 } & $\begin{array}{l}\text { Blaine Fineness } \\
\left(\mathrm{m}^{2} / \mathrm{kg}\right) \text {, minimum }\end{array}$ & - & - & - & 15 \\
\hline & $\begin{array}{l}\text { Percentage remaining } \\
\text { on number } 325 \text { ( } 45 \\
\text { micron) sieve }\end{array}$ & $\begin{array}{l}34 \\
\text { (maximum) }\end{array}$ & $\begin{array}{l}34 \\
\text { (maximum) }\end{array}$ & $\begin{array}{l}34 \\
\text { (maximum) }\end{array}$ & $\begin{array}{l}10 \\
\text { (minimum) }\end{array}$ \\
\hline & $\begin{array}{l}\text { Strength Activity Index } \\
\text { with cement (\%) at } 7 \\
\text { days, minimum }\end{array}$ & 75 & 75 & 75 & 85 \\
\hline & $\begin{array}{l}\text { Strength Activity Index } \\
\text { with cement (\%) at } 28 \\
\text { days, minimum }\end{array}$ & 75 & 75 & 75 & - \\
\hline & $\begin{array}{l}\text { Autoclave expansion } \\
\text { (\%), maximum }\end{array}$ & 0.8 & 0.8 & 0.8 & - \\
\hline & $\begin{array}{l}\text { Dry Shrinkage (\%) } \\
\text { at } 28 \text { days, maximum }\end{array}$ & 0.03 & 0.03 & 0.03 & - \\
\hline 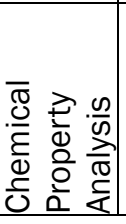 & $\begin{array}{l}\text { Sum of Iron Oxide } \\
\left(\mathrm{Fe}_{2} \mathrm{O}_{3}\right), \mathrm{Aluminum} \\
\text { Oxide }\left(\mathrm{Al}_{2} \mathrm{O}_{3}\right) \text {, and } \\
\text { Silicon Dioxide }\left(\mathrm{SiO}_{2}\right) \text {, } \\
\text { minimum }\end{array}$ & 70 & 70 & 50 & - \\
\hline
\end{tabular}




\begin{tabular}{|c|c|c|c|c|c|}
\hline & \multirow{3}{*}{ Requirements } & \multicolumn{3}{|c|}{ ASTM C618 } & \multirow{3}{*}{$\begin{array}{l}\text { ASTM C1240 } \\
\text { Silica fume }\end{array}$} \\
\hline & & \multirow{2}{*}{$\begin{array}{l}\text { Natural } \\
\text { Pozzolan } \\
\text { Class N* }\end{array}$} & \multicolumn{2}{|l|}{ Fly ash } & \\
\hline & & & Class F* & Class C* & \\
\hline & $\begin{array}{l}\text { Sulfur Trioxide }\left(\mathrm{SO}_{3}\right) \text {, } \\
\text { maximum }\end{array}$ & 4 & 5 & 5 & - \\
\hline & $\begin{array}{l}\text { Moisture content, } \\
\text { maximum }\end{array}$ & 3 & 3 & 3 & 3 \\
\hline & $\begin{array}{l}\text { Loss on ignition (\%), } \\
\text { maximum }\end{array}$ & 10 & 6 & 6 & 6 \\
\hline & $\begin{array}{l}\text { Silicon Dioxide }\left(\mathrm{SiO}_{2}\right) \text {, } \\
\text { minimum }\end{array}$ & - & - & - & 85 \\
\hline \multicolumn{6}{|c|}{$\begin{array}{l}\text { *Class N: Raw or calcined natural pozzolan that comply with the application requirements for } \\
\text { the class as given herein, such as some diatomaceous earths; opaline cherts and shales; } \\
\text { thufs and volcanic ashes or pumicites, calcined or uncalcined; and various materials requiring } \\
\text { calcinations such as some clays and shales. } \\
\text { *Class F: Fly ash normally produced from burning bituminous coal that meets the applicable } \\
\text { requirements for this class as given herein. This class of fly ash has pozzolanic properties. } \\
\text { *Class C: Fly ash normally produced from lignite or sub bituminous coal that meets the } \\
\text { applicable requirements for this class, as given herein. The class of fly ash, in addition to } \\
\text { having pozzolanic properties, also has some cementitious properties. }\end{array}$} \\
\hline
\end{tabular}

\subsection{Physical tests}

The following physical tests were conducted on the pozzolan specimens:

- strength activity index (ASTM C311-00)

- density (ASTM C188-95)

- fineness per sieve analysis (ASTM C311-00)

- Blaine fineness (ASTM C204-00)

- increase in drying shrinkage (ASTM C157)

- expansion stability using autoclave (ASTM C157).

Two types of specimens were used: (1) a control specimen with $100 \%$ natural pozzolan S1 and sand and (2) an activity specimen with 80\% cement, $20 \%$ natural pozzolan S1, and sand. The chemical composition and physical properties of the control specimen were used for comparison with the activity specimen. The results of the physical tests are shown in Tables 40 and 41. 
Table 40. Strength activity index results.

\begin{tabular}{|l|l|l|}
\hline Property & $\begin{array}{l}\text { Control } \\
\text { specimen }\end{array}$ & $\begin{array}{l}\text { Activity } \\
\text { specimen }\end{array}$ \\
\hline $\begin{array}{l}\text { Shear Stress }\left(\mathrm{N} / \mathrm{mm}^{2}\right) \\
\text { at } 7 \text { days }\end{array}$ & 29.5 & 22.6 \\
\hline Strength Activity Index at 7days,\% & 76.6 & 28.0 \\
\hline Shear Stress $\left(\mathrm{N} / \mathrm{mm}^{2}\right)$ at 28 days & 36.0 & \multicolumn{2}{|l|}{} \\
\hline Strength Activity Index at 28 days,\% & 77.8 & \\
\hline
\end{tabular}

Table 41. Density, fineness, dry shrinkage, and volume results.

\begin{tabular}{|c|c|c|}
\hline \multicolumn{2}{|c|}{ Physical Property } & Results \\
\hline \multicolumn{2}{|l|}{ Density } & $\mathrm{g} / \mathrm{cm}^{3}$ \\
\hline \multirow[t]{2}{*}{ Fineness } & Sieve analysis & $10.8 \%$ \\
\hline & Blaine & $359 \mathrm{~m}^{2} / \mathrm{kg}$ \\
\hline \multicolumn{2}{|c|}{ Increase in drying shrinkage after 28 days } & $-0.009 \%$ * \\
\hline \multicolumn{2}{|c|}{$\begin{array}{l}\text { Volume stability (autoclave expansion / } \\
\text { contraction) }\end{array}$} & $0.2 \%$ \\
\hline
\end{tabular}

\subsection{Chemical tests}

Chemical analysis of the specimens was conducted to determine the effectiveness of the natural pozzolan in contributing to sulfate resistance. The results of the chemical analysis are given in Tables 42 and 43.

Table 42. Chemical composition.

\begin{tabular}{|l|l|l|}
\hline $\begin{array}{l}\text { Chemical } \\
\text { Composition,\% }\end{array}$ & Control Cement & Natural Pozzolan S1 \\
\hline $\mathrm{SiO}_{2}$ & 19.26 & 48.44 \\
\hline $\mathrm{CaO}$ & 63.34 & 8.53 \\
\hline $\mathrm{Fe}_{2} \mathrm{O}_{3}$ & 3.6 & 13.3 \\
\hline $\mathrm{Al}_{2} \mathrm{O}_{3}$ & 5.35 & 15.97 \\
\hline $\mathrm{MgO}$ & 2.36 & 7.98 \\
\hline $\mathrm{SO}_{3}$ & 2.48 & 0.1 \\
\hline $\mathrm{K}_{2} \mathrm{O}$ & 0.51 & 1.37 \\
\hline $\mathrm{Cl}$ & 0.011 & 0.012 \\
\hline
\end{tabular}


Table 43. Chemical properties.

\begin{tabular}{|l|l|l|}
\hline Property & Control Cement & Natural Pozzolan S1 \\
\hline Loss on Ignition,\% & 2.35 & 1.26 \\
\hline Moisture Content,\% & - & 0.34 \\
\hline PH & - & 9.0 \\
\hline Carbon Content,\% & - & 0.33 \\
\hline Insoluble Residue,\% & 0.74 & - \\
\hline
\end{tabular}

\subsection{Physical analysis}

The physical properties of the natural pozzolan specimens are compared with the ASTM requirements for fly ash and silica fume in Table 44. As shown in this table, the natural pozzolan specimens met the requirements for fly ash but not for silica fume. The fineness values were less than $34 \%$, and the strength activity indexes were greater than $75 \%$. Their volume stabilities were less than $0.8 \%$, and the increase in drying shrinkage at 28 days was less than $0.03 \%$. While the natural pozzolan met the silica fume requirements for Blaine fineness and the percentage remaining on the 45 micron sieve, it is significant that it did not meet the 7 day strength activity index of $85 \%$.

Table 44. Comparison between pozzolan physical properties and ASTM requirements.

\begin{tabular}{|c|c|c|c|c|c|}
\hline \multirow[t]{2}{*}{ Test } & \multirow{2}{*}{$\begin{array}{l}\text { Results for } \\
\text { Pozzolan } \\
\text { S1 }\end{array}$} & \multicolumn{3}{|c|}{ ASTM C618 Requirements for fly ash } & \multirow{2}{*}{$\begin{array}{l}\text { ASTM C1240 } \\
\text { Requirements } \\
\text { for silica fume }\end{array}$} \\
\hline & & Class $\mathrm{N}$ & Class $\mathrm{F}$ & Class C & \\
\hline $\begin{array}{l}\text { Blaine } \\
\text { Fineness } \\
\left(\mathrm{m}^{2} / \mathrm{kg}\right)\end{array}$ & & - & - & - & $\begin{array}{l}15 \\
\text { (minimum) }\end{array}$ \\
\hline $\begin{array}{l}\text { Percentage } \\
\text { remaining on } \\
45 \text { micron } \\
\text { sieve }\end{array}$ & & $\begin{array}{l}34 \\
\text { (maximum) }\end{array}$ & $\begin{array}{l}34 \\
\text { (maximum) }\end{array}$ & $\begin{array}{l}34 \\
\text { (maximum) }\end{array}$ & $\begin{array}{l}10 \\
\text { (minimum) }\end{array}$ \\
\hline $\begin{array}{l}\text { Strength } \\
\text { Activity Index } \\
\text { at } 7 \text { days, } \%\end{array}$ & 76.6 & $\begin{array}{l}75 \\
\text { (minimum) }\end{array}$ & $\begin{array}{l}75 \\
\text { (minimum) }\end{array}$ & $\begin{array}{l}75 \\
\text { (minimum) }\end{array}$ & $\begin{array}{l}85 \\
\text { (minimum) }\end{array}$ \\
\hline $\begin{array}{l}\text { Strength } \\
\text { Activity Index } \\
\text { at } 28 \text { days, } \%\end{array}$ & 77.8 & $\begin{array}{l}75 \\
\text { (minimum) }\end{array}$ & $\begin{array}{l}75 \\
\text { (minimum) }\end{array}$ & $\begin{array}{l}75 \\
\text { (minimum) }\end{array}$ & - \\
\hline $\begin{array}{l}\text { Autoclave } \\
\text { expansion/ } \\
\text { contraction,\% }\end{array}$ & 0.02 & $\begin{array}{l}0.8 \\
\text { (maximum) }\end{array}$ & $\begin{array}{l}0.8 \\
\text { (maximum) }\end{array}$ & $\begin{array}{l}0.8 \\
\text { (maximum) }\end{array}$ & - \\
\hline $\begin{array}{l}\text { Percentage of } \\
\text { Dry Shrinkage } \\
\text { at } 28 \text { days }\end{array}$ & -0.009 & $\begin{array}{l}0.03 \\
\text { (maximum) }\end{array}$ & $\begin{array}{l}0.03 \\
\text { (maximum) }\end{array}$ & $\begin{array}{l}0.03 \\
\text { (maximum) }\end{array}$ & - \\
\hline
\end{tabular}




\subsection{Chemical analysis}

The chemical test results of the natural pozzolan specimen were compared with the ASTM requirements, as shown in Table 45. The natural pozzolan specimens met all the requirements for fly ash but did not meet the $85 \%$ silicon dioxide requirement for silica fume. It is worth noting that the ASTM specification for class $\mathrm{F}$ fly ash requires the sum of $\mathrm{Fe}_{2} \mathrm{O}_{3}, \mathrm{Al}_{2} \mathrm{O}_{3}$, and $\mathrm{SiO}_{2}$ to be at least 70\%. It also specifies $\mathrm{SO}_{3}$ less than $5 \%$, moisture content less than $3 \%$, and loss on ignition less than $6 \%$.

Table 45. Comparison between pozzolan chemical properties and ASTM requirements.

\begin{tabular}{|c|c|c|c|c|c|}
\hline \multirow[t]{3}{*}{ Test } & \multirow{3}{*}{$\begin{array}{l}\text { Results for } \\
\text { Pozzolan } \\
\text { S1 }\end{array}$} & \multicolumn{4}{|l|}{ ASTM C618 } \\
\hline & & \multirow{2}{*}{$\begin{array}{l}\text { Natural } \\
\text { pozzolan } \\
\text { Class } \mathrm{N}\end{array}$} & \multicolumn{2}{|l|}{ Fly ash } & \multirow[t]{2}{*}{ Silica fume } \\
\hline & & & Class $\mathrm{F}$ & Class C & \\
\hline $\begin{array}{l}\text { Sum of Iron } \\
\text { Oxide } \\
\left.\text { (Fen } \mathrm{F}_{3}\right), \\
\text { Aluminum } \\
\text { Oxide }\left(\mathrm{Al}_{2} \mathrm{O}_{3}\right) \text {, } \\
\text { and } \mathrm{Silicon} \\
\text { Dioxide } \\
\left(\mathrm{SiO}_{2}\right), \%\end{array}$ & 77.61 & $\begin{array}{l}70 \\
\text { (minimum) }\end{array}$ & $\begin{array}{l}70 \\
\text { (minimum) }\end{array}$ & $\begin{array}{l}50 \\
\text { (minimum) }\end{array}$ & - \\
\hline $\begin{array}{l}\text { Sulfur } \\
\text { Trioxide } \\
\left(\mathrm{SO}_{3}\right), \%\end{array}$ & 0.34 & $\begin{array}{l}4 \\
\text { (maximum) }\end{array}$ & $\begin{array}{l}5 \\
\text { (maximum) }\end{array}$ & $\begin{array}{l}5 \\
\text { (maximum) }\end{array}$ & - \\
\hline $\begin{array}{l}\text { Moisture } \\
\text { content,\% }\end{array}$ & 0.1 & $\begin{array}{l}3 \\
\text { (maximum) }\end{array}$ & $\begin{array}{l}3 \\
\text { (maximum) }\end{array}$ & $\begin{array}{l}3 \\
\text { (maximum) }\end{array}$ & - \\
\hline $\begin{array}{l}\text { Loss on } \\
\text { ignition,\% }\end{array}$ & 1.26 & $\begin{array}{l}10 \\
\text { (maximum) }\end{array}$ & $\begin{array}{l}6 \\
\text { (maximum) }\end{array}$ & $\begin{array}{l}6 \\
\text { (maximum) }\end{array}$ & $\begin{array}{l}6 \\
\text { (maximum) }\end{array}$ \\
\hline $\begin{array}{l}\text { Silicon } \\
\text { Dioxide } \\
\left(\mathrm{SiO}_{2}\right), \%\end{array}$ & 48.44 & - & - & - & $\begin{array}{l}85 \\
\text { (minimum) }\end{array}$ \\
\hline
\end{tabular}




\section{Conclusions}

This report has documented a program of physical and chemical laboratory tests of pozzolans and cementitious materials containing them. Analysis of the test results has yielded the following conclusions.

\subsection{Pozzolan as a mortar admixture}

One type of pozzolan was suitable for replacement in Type M mortars and one was suitable for replacement in Type $\mathrm{N}$ mortars, although the amount of pozzolan in each specimen varied.

Test results indicated that Pozzolan $\mathrm{S}$ is a candidate for use in Type $\mathrm{M}$ mortar, but only in limited quantities. Results suggests a maximum of $15 \%$ cement replacement, but a lower fraction may be optimal. Also, the chemical analyses performed here should be repeated or extended to validate the findings before Pozzolan S can be recommended for usage in a major construction project.

Pozzolan $\mathrm{G}$ is an excellent candidate to replace up to $35 \%$ of Portland cement in Type N mortar, but not Type M. As with Pozzolan S, however, lime has a detrimental effect on compressive strength. The quantity of cement that may be saved using this pozzolan as a substitute is significant.

Overall, the mortar cube specimens containing pozzolan less strength and stiffness but more ductility than typical mortars.

\subsection{Pozzolan S as a fly ash substitute}

Pozzolan S was found to provide a satisfactory substitute for fly ash and other natural pozzolans when tested against ASTM C618-00. It was clearly found to be effective in controlling ASR. It also produces about 15\% less heat of hydration than Class $\mathrm{F}$ fly ash, whereas Class $\mathrm{F}$ fly ash produces about 30\% less heat of hydration than Portland cement only.

Pozzolan specimens crushed to a size of 20 microns met the chemical and physical requirements for fly ash. The fineness values were less than $34 \%$, and the strength activity indexes at 7 and 28 days were greater than $75 \%$. 
Volume stabilities were less than $0.8 \%$, and the increase in drying shrinkage at 28 days was less than $0.03 \%$. The percentage of total iron oxide, aluminum oxide, and silicon dioxide was greater than $70 \%$. The percentage of sulfur trioxide was less than 5\%. Moisture content was less that $3 \%$. Loss on ignition was less than $6 \%$.

Based on the above findings, it is concluded that the fineness and chemical and physical properties of raw is identical to, and can be substituted for Class C and Class F fly ash.

\subsection{Pozzolan $\mathrm{S}$ as a silica fume substitute}

Pozzolan S did not meet the ASTM C1240-00 chemical and physical requirements for silica fume. The strength activity index at 7 days was less than $85 \%$, and the percentage of silicon dioxide was not met. However, it met the requirements for the percentage remaining on the 45 micron sieve at greater than $10 \%$, moisture content less than $3 \%$, loss on ignition less than $6 \%$, and Blaine fineness greater than $15 \mathrm{~m}^{2} / \mathrm{kg}$.

Based on the above findings, it is concluded that Pozzolan $\mathrm{S}$ is not a suitable replacement for ASTM C140 silica fume despite meeting the requirements for fineness, moisture content, and loss on ignition. 


\section{References}

ASTM C109. Test Method for Compressive Strength of Hydraulic Cement Mortars (Using 2-in. or 50-mm Cube Specimens). West Conshohocken, PA: ASTM International.

ASTM C150. Specification for Portland Cement. West Conshohocken, PA: ASTM International.

ASTM C157. 08. Standard Test Method for Length Change of Hardened HydraulicCement Mortar and Concrete. West Conshohocken, PA: ASTM International.

ASTM C186. Standard Test Method for Heat of Hydration of Hydraulic Cement. West Conshohocken, PA: ASTM International.

ASTM C188. Standard Test Method for Density of Hydraulic Cement. West Conshohocken, PA: ASTM International.

ASTM C204. Standard Test Methods for Fineness of Hydraulic Cement by AirPermeability Apparatus. West Conshohocken, PA: ASTM International.

ASTM C305. Standard Practice for Mechanical Mixing of Hydraulic Cement Pastes and Mortars of Plastic Consistency. West Conshohocken, PA: ASTM International.

ASTM C311. Standard Test Methods for Sampling and Testing Fly Ash or Natural Pozzolans for Use in Portland-Cement Concrete. West Conshohocken, PA: ASTM International.

ASTM C490. Standard Practice for Use of Apparatus for the Determination of Length Change of Hardened Cement Paste, Mortar, and Concrete. West Conshohocken, PA: ASTM International.

ASTM C618. Specification for Coal Fly Ash and Raw or Calcined Natural Pozzolan for Use as a Mineral Admixture in Portland Cement Concrete. West Conshohocken, PA: ASTM International.

ASTM C778. Standard Specification for Standard Sand. West Conshohocken, PA: ASTM International.

ASTM C1240. Standard Specification for Silica Fume Used in Cementitious Mixtures. West Conshohocken, PA: ASTM International.

ASTM C1260. Standard Test Method for Potential Alkali Reactivity of Aggregates (Mortar-Bar Method). West Conshohocken, PA: ASTM International.

Björk, Folke, and Carl Axel Eriksson. 2002. Measurement of Alkalinity in Concrete by a simple Procedure, to Investigate Transport of Alkaline Material from the Concrete Slab to a Self-levelling Screed. Construction and Building materials. 16:535 - 542 . 
Dolar-Mantuani, L. 1983. Handbook of Concrete Aggregates, A Petrographic and Technological Evaluation. Noyes Publication: 79-125.

Gibbons, Pat. 1997. Pozzolans for Lime Mortars, The Conservation and Repair of Ecclesiastical Buildings. http://www.buildingconservation.com/articles/pozzo/pozzo.htm

Grattan-Bellew, P.E., G. Cybanski, B. Fournier, L. Mitchell. 2003. "Proposed universal accelerated test for alkali-aggregate reaction: the concrete microbar test". Cement Concrete and Aggregates 25 (2): 29- 34.

Hobbs, D.W. 1988. Alkali-Silica Reaction in Concrete, London: Thomas Telford: 183.

Lane et al. Date Unknown. Properties and use of Fly Ash in Portland Cement Concrete: 81-92.

Mindess, Sidney, and J . Francis Young. 1981. Concrete. Englewood Cliffs, NJ : PrenticeHall, Inc: 25.

Sardela, Mauro. 2009. Siemens D5000 Theta/ Theta XRD System.

Stanton, T. E. 1940. Expansion of concrete through reaction between cement and aggregate, Proceedings of the American Society of Civil Engineers 66(10):17811811.

Thomas, M. D. A. and F. A. Innis. 1998. Use of the Accelerated Mortar-Bar Test for Evaluating the Efficacy of Mineral Admixtures for Controlling Expansion Due to Alkali-Silica Reaction. In Symposium on Developments in Test Methods for Alkali-Silica Reactions. December.

Wang, H. and Giliott, J . E. 1993. Effect Of Three Zeolite-containing Natural Pozzolanic Materials On Alkali-Silica Reaction, J ournal of Cement, Concrete, and Aggregates. J uly: 15(1). 


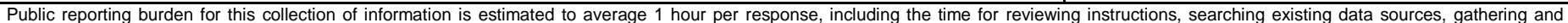

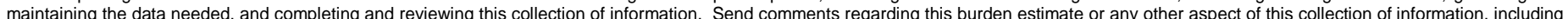

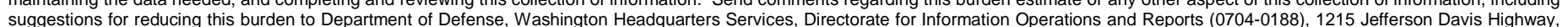

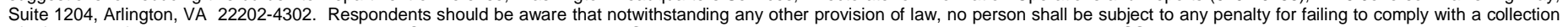
of information if it does not display a currently valid OMB control number. PLEASE DO NOT RETURN YOUR FORM TO THE ABOVE ADDRESS.

\begin{tabular}{l|l} 
1. REPORT DATE (DD-MM-YYYY) & 2. REPORT TYPE
\end{tabular}

December 2011 Final

\section{TITLE AND SUBTITLE}

The Use of Natural Pozzolan in Concrete as an Additive or Substitute for Cement

\section{AUTHOR(S)}

Ghassan K. Al-Chaar, Mouin Alkadi, David A. Yaksic, and Lisa A. Kallemyn

\section{DATES COVERED (From - To)}

5a. CONTRACT NUMBER

5b. GRANT NUMBER

5c. PROGRAM ELEMENT NUMBER

5d. PROJECT NUMBER

5e. TASK NUMBER

5f. WORK UNIT NUMBER

8. PERFORMING ORGANIZATION REPORT NUMBER

. PERFORMING ORGANIZATION NAME(S) AND ADDRESS(ES) Construction Engineering Research Laboratory P.O. Box 9005

Champaign, IL 61826-9005
9. SPONSORING I MONITORING AGENCY NAME(S) AND ADDRESS(ES)

Headquarters, U.S. Army Corps of Engineers

441 G Street NW

Washington, DC 20314-1000
10. SPONSOR/MONITOR'S ACRONYM(S) HQUSACE

11. SPONSOR/MONITOR'S REPORT NUMBER(S)

\section{DISTRIBUTION I AVAILABILITY STATEMENT}

Approved for public release; distribution is unlimited.

\section{SUPPLEMENTARY NOTES}

\section{ABSTRACT}

Chemical, physical, and mechanical tests were conducted to assess the feasibility of using naturally occurring pozzolan as a cement mortar additive. One test series assessed the feasibility of substituting pozzolan for a portion of cement in concrete mortar mixtures. The chemical composition of five natural pozzolans was determined. Compressive testing was conducted on specimens with varying amounts and types of pozzolan. One pozzolan was found suitable for cement replacement in Type M mortars, and one was suitable for cement replacement in Type $\mathrm{N}$ mortars at a different proportion. The results indicate that, within certain mixture percentage limits, partial replacement of cement with pozzolan does not compromise mortar compressive strength. A second test series evaluated four mixes prepared using three types of natural pozzolan as well as Class F fly ash. The effectiveness of each cement replacement material in controlling alkali-silica reactions was studied. Correlations were made between the mechanical properties of the proposed mixes and a Portland cement control mix. The results were also compared with industry standards for mortars made with fly ash and silica fume. Results indicate that one type of pozzolan may be used as a substitute for fly ash, but not for silica fume.

\section{SUBJECT TERMS}

concrete, additive, cement replacement material, testing, pozzolan

\section{SECURITY CLASSIFICATION OF:}

\section{a. REPORT}

Unclassified

\section{b. ABSTRACT}

Unclassified c. THIS PAGE

Unclassified
17. LIMITATION OF ABSTRACT

\section{NUMBER} OF PAGES

98 19a. NAME OF RESPONSIBLE PERSON

19b. TELEPHONE NUMBER (include area code) 